\title{
Monitoring Plan for Fiscal Year 1999 \\ Borehole Logging at 200 East Area Specific Retention Facilities
}

D.G. Horton

June 1999

Prepared for

the U.S. Department of Energy under Contract DE-AC06-76RLO 1830

Pacific Northwest National Laboratory

Richland, Washington 99352 



\section{DISCLAIMER}

This report was prepared as an account of work sponsored by an agency of the United States Government. Neither the United States Government nor any agency thereof, nor any of their employees, make any warranty, express or implied, or assumes any legal liability or responsibility for the accuracy, completeness, or usefulness of any information, apparatus, product, or process disclosed, or represents that its use would not infringe privately owned rights. Reference herein to any specific commercial product, process, or service by trade name, trademark, manufacturer, or otherwise does not necessarily constitute or imply its endorsement, recommendation, or favoring by the United States Government or any agency thereof. The views and opinions of authors expressed herein do not necessarily state or reflect those of the United States Government or any agency thereof. 


\section{DISCLAIMER}

Portions of this document may be illegible in electronic image products. Images are produced from the best available original document. 


\section{Summary}

The Hanford Groundwater Monitoring Project's vadose zone monitoring effort for fiscal year (FY) 1999 involves monitoring 30 boreholes for moisture content and gamma-ray emitting radionuclides. The boreholes are associated with specific retention trenches and cribs in the 200 East Area of the Hanford Site. The facilities to be monitored are the 216-A-2, -4 , and -7 cribs, the 216-A-18 trench, the 216-B-14 through -19 cribs, the $216-\mathrm{B}-20$ through $-34,-53 \mathrm{~A}$, and -58 trenches, the $216-\mathrm{B}-35$ through -42 trenches, and the 216-C-5 crib.

This monitoring plan describes the facilities and the vadose zone at the cribs and trenches to be monitored; the field activities to be accomplished; the constituents of interest and the monitoring methods, including calibration issues; and the quality assurance and quality control requirements governing the monitoring effort.

The results from the FY 1999 monitoring will show the current configuration of subsurface contamination and will be compared with past monitoring results to determine whether changes in contaminant distribution have occurred since the last monitoring effort. 



\section{Contents}

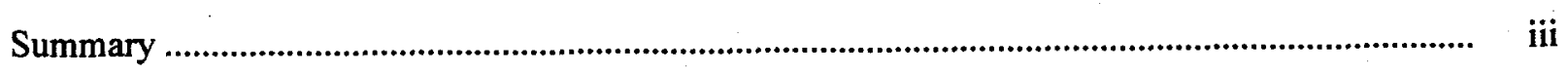

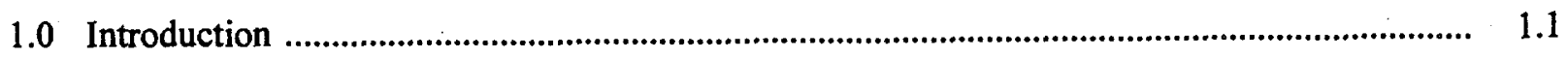

2.0 Previous Monitoring of Specific Retention Facilities .......................................................... 2.1

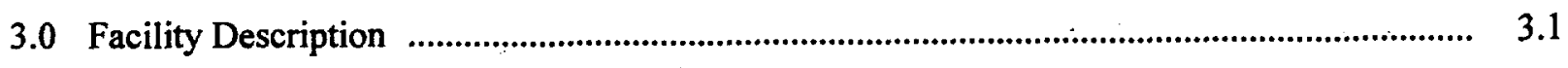

3.1 PUREX Facilities.................................................................................................... 3.1

3.2 BC Controlled Area Cribs ........................................................................................... 3.1

3.3 BC Controlled Area Trenches............................................................................................. 3.2

3.4 BX Trenches ......................................................................................................... 3.2

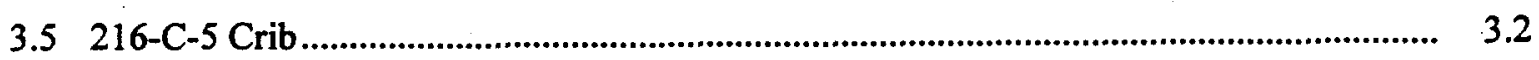

4.0 Geologic Setting of the 200 East Specific Retention Facilities .............................................. 4.1

4.1 Geology of the 216-A-2 and 216-A-4 Cribs................................................................. 4.3

4.2 Geology of the 2:16-A-7 Crib and the 216-A-18 Trench .................................................... 4.3

4.3 Geology of the BC Controlled Area Cribs and Trenches ................................................ 4.5

4.4 Geology of the BX Trenches ......................................................................................... 4.6

4.5 Geology of the 216-C-5 Crib ................................................................................... 4.7

5.0 Vadose Monitoring $\quad$.................................................................................................................. 5.1

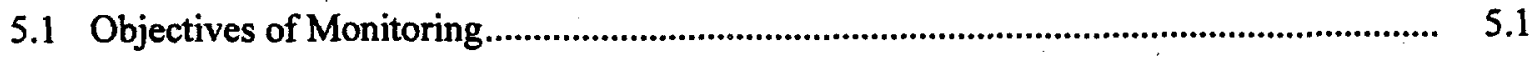

5.2 Constituents of Interest and Detection Limits ................................................................ 5.1

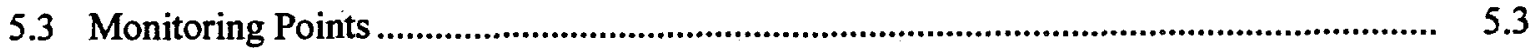

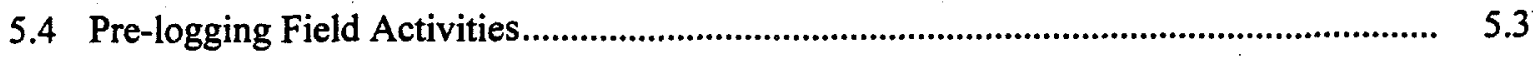

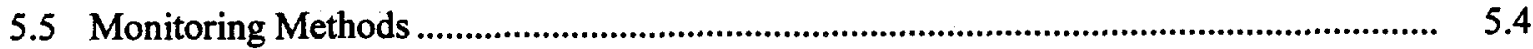

5.5.1 Spectral Gamma-Ray Logging ....................................................................... 5.4

5.5.2 Neutron Moisture Tool ...................................................................................... 5.12 


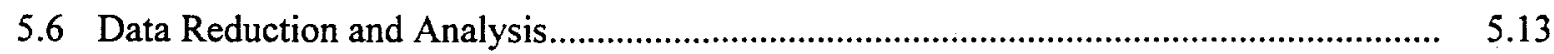

5.6.1 Spectral Gamma Ray Data....................................................................... 5.13

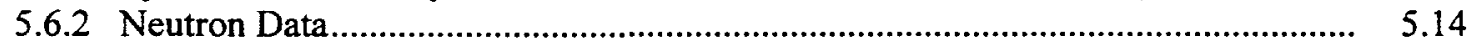

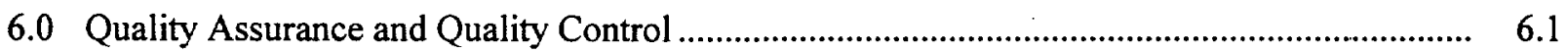

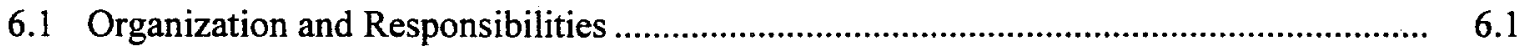

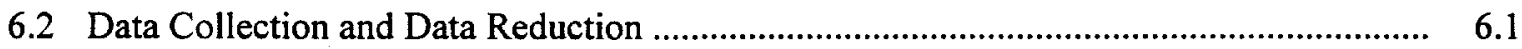

6.3 Performance and System Audits and Corrective Actions........................................... 6.2

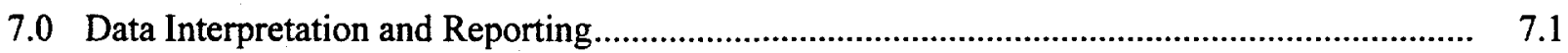

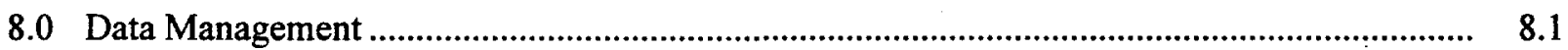

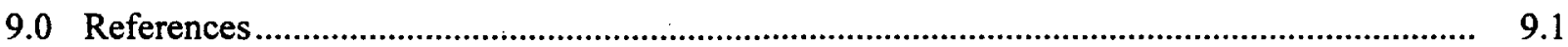

Appendix A -Facility Construction As-Built Diagrams for 200 East Area Specific Retention Facilities Scheduled for Vadose Zone Monitoring in Fiscal Year 1999.................... A.1

Appendix B -Contaminant Inventories for Facilities Scheduled to be Monitored in Fiscal Year 1999 ......................................................................................... B. B

Appendix C - Well Construction and Completion Summaries for Boreholes and Wells Scheduled for Vadose Zone Monitoring in Fiscal Year 1999

\section{Figures}

1.1 Map of the 200 East Area Showing the Locations of Specific Retention Facilities Associated with Boreholes Scheduled for Logging in Fiscal Year 1999

4.1 Generalized Stratigraphy for the 200 East Area.

5.1 Map of the 216-A-2 and 216-A-4 Cribs Showing the Locations of Boreholes to be Monitored in Fiscal Year 1999

5.2 Map of the 216-A-7 Crib and the 216-A-18 Trench Showing the Locations of Boreholes to be Monitored in Fiscal Year 1999.

5.3 Map of the 216-B-14 through -19 Specific Retention Cribs in the BC Controlled Area Showing Locations of Boreholes to be Monitored in Fiscal Year 1999

5.4 Map of the 216-B-20 through -34, -53A, and -58 Specific Retention Trenches in the BC Controlled Area Showing Locations of Boreholes to be Monitored in Fiscal Year 1999 
5.5 Map of the 216-B-35 through -42 Specific Retention Trenches West of the 241-BX

Tank Farm Showing the Locations of Boreholes to be Monitored in Fiscal Year 1999

5.6 Map of the 216-C-5 Specific Retention Crib Showing the Location of the Borehole to be Monitored During Fiscal Year 1999

\section{Tables}

2.1 Previous Logging Results for the Specific Retention Facilities to be Logged in Fiscal Year 1999

5.1 Detectable Radionuclides..

5.2 Wells to be Logged at 200 East Area Specific Retention Facilities.

6.1 Standards for Operating Procedures. 


\subsection{Introduction}

The Hanford Groundwater Monitoring Project's fiscal year (FY) 1999 vadose zone monitoring activities consist of spectral gamma-ray and neutron moisture logging of 30 boreholes at specific retention cribs and trenches in the 200 East Area. This plan describes past monitoring at these sites and provides brief descriptions of the facilities and their geologic setting. The plan also includes descriptions of the specific monitoring to be done including the boreholes to be logged, the methods of data acquisition, data reduction, data evaluation, and finally, the quality control, data management and data reporting for this effort.

Specific retention facilities were chosen to be monitored in FY 1999 because they are among the highest priority sites as determined by an evaluation of past-practice liquid waste disposal facilities. The evaluation used eleven criteria to determine the potential impact of contamination on groundwater quality. The details of the evaluation and the prioritization criteria and process are found in Horton et al. (1998).

The Hanford Groundwater Monitoring Project decided to monitor the high priority, specific retention facilities in the 200 East Area in FY 1999 and defer monitoring of specific retention facilities in 200 West Area until FY 2000 in order to reduce deployment and field costs. The facilities to be monitored are the 216-A-2, -4, and -7 cribs; the 216-A-18 trench; the 216-B-14 through -19 cribs (BC-cribs in the BC Controlled Area); the 216-B-20 through -34, -53A, and -58 trenches (BC-trenches in the BC Controlled Area); the 216-B-35 through -42 trenches; and the 216-C-5 crib. Figure 1.1 shows the location of these facilities in 200 East Area.

The monitoring seeks to answer the question, "What is the configuration of subsurface contamination and has it changed since it was last measured?" Historical gross gamma-ray monitoring results exist for all of the boreholes to be monitored in FY 1999. Those results will be used as the baseline for comparing new data to help answer this question. Also, much of the data gathered during FY 1999 monitoring will serve as a baseline for future logging because many of the boreholes have never been logged by spectral gamma-ray methods and none have historic neutron moisture data. 


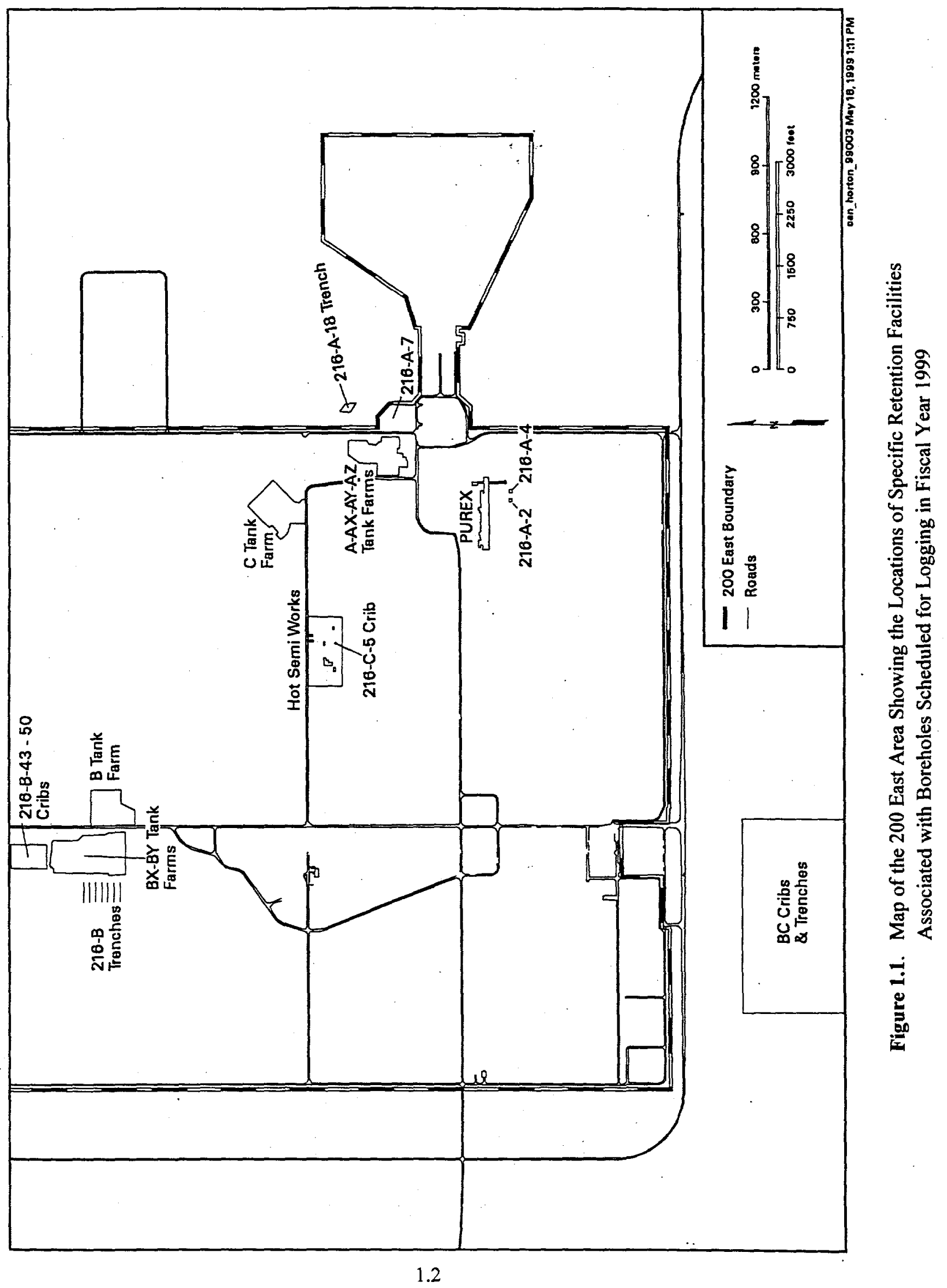




\subsection{Previous Monitoring of Specific Retention Facilities}

Table 2.1 lists the boreholes to be monitored in FY 1999, their associated facility and any previously obtained geophysical logs from the boreholes. The historical logs are mostly gross gamma-ray logs, but some of the more recent logs are spectral gamma-ray logs. Table 2.1 also lists the contaminated intervals associated with each borehole as interpreted from the most recent log.

The earliest comprehensive collection and discussion of gross gamma-ray profiles from boreholes at specific retention facilities is included in Fecht et al. (1977). They interpreted the gross gamma-ray profiles for about $100 \mathrm{crib}$ facilities including most of the specific retention cribs and trenches in the 200 East Area. They compared the most current profiles available at that time with previous profiles to interpret changes in subsurface distribution of gamma emitting radionuclides.

Gross gamma-ray logs have been collected and compiled subsequent to Fecht et al. (1977) (see Addition et al. 1978a and 1978b) but no comparable discussion or presentation of the data has been made.

In 1992, compilations were published of all known geophysical logging done in the B-Plant aggregate area (Teel et al. 1992), the PUREX aggregate area (Chamness et al. 1992a), and the C-Plant aggregate area (Chamness et al. 1992b). Scientists were able to delineate subsurface contamination in the PUREX, B-Plant, and Semiworks Source Operable Unit areas by using these compilations, as well as results from the earlier reports (Fecht et al. 1977; Additon et al. 1978a, 1978b; Chamness 1986), the few subsequent spectral gamma-ray logs (Brodeur et al. 1993), and unpublished gross gamma-ray logs in the Source Aggregate Area Management Study Reports (DOE 1993a, 1993b, and 1993c). Those reports include the most recent discussions of vadose monitoring results and show isopach maps of elevated gamma activities beneath some past-practice, liquid waste disposal facilities.

Historical logs from boreholes at the 216-A-2 and 216-A-4 cribs were re-evaluated in the PUREX Source Aggregate Area Management Study Report (DOE 1993a). The re-evaluation noted significant levels of gamma activity near the 216-A-2 and 216-A-4 cribs. The top of the contaminated zone corresponded to the top of the Hanford sand sequence $(\mathrm{Hs})$ (see description of geology below) and the base of the crib. The lowest depth of contamination was not determined because contamination was deeper than the total depth of the boreholes.

Historical logs from boreholes monitoring the 216-B-4 through -9 cribs in the $\mathrm{BC}$ Controlled Area were re-evaluated in the B-Plant Source Aggregate Area Management Study Report (DOE 1993b). The conclusions of that re-evaluation agreed with the previous evaluation of Fecht et al. (1977) that migration of contaminants had occurred beneath all of the cribs and that breakthrough to the water table may have occurred beneath $216-\mathrm{B}-4$ and -6 cribs. Intervals of gamma radiation occurred in all wells in the 216-B-4 though -9 area, and there was some evidence that vertical migration was controlled in some wells by a silty layer occurring at about $29-\mathrm{m}(95-\mathrm{ft})$ depth. The distribution of boreholes in the crib area is inadequate to define the lateral extent of contamination. However, gamma-ray profiles from two wells taken before their associated crib was used for liquid disposal showed subsurface contamination indicating lateral migration had occurred. 
Historical logs from boreholes monitoring the 216-B-20 through $-34,-52,-53 \mathrm{~A},-53 \mathrm{~B},-54$, and -58 trenches in the BC Controlled Area were re-evaluated in the B-Plant Source Aggregate Area Management Study Report (DOE 1993b). The results were consistent with the conclusions of Fecht et al. (1977). Elevated gamma activity occurred in most boreholes located between the trenches. However, most boreholes did not extend below the level of elevated gamma activity, so the vertical extent of contamination could not be defined. Evidence for lateral migration was present in historic gamma logs from most perimeter boreholes, but that activity had decreased to background level in all but one borehole (299-E13-7) by 1993 .

The B-Plant Source Aggregate Area Management Study Report (DOE 1993b) re-evaluated historical logs from boreholes monitoring the 216-B-35 through -42 trenches west of the 241-BX tank farm. The results were consistent with the conclusions of Fecht et al. (1977) with one exception. The exception indicated deeper penetration of activity in borehole 299-E33-21 than previously reported. High levels of activity were detected at the top of the Hanford upper gravel sequence (Hug) and in a gravelly bed at the top of the Hanford middle sand sequence (Hs). Based on the available historical logs, there was no evidence for vertical or lateral migration of contamination.

Historical logs from boreholes monitoring the 216-C-5 specific retention crib were re-evaluated in the Semiworks Source Aggregate Area Management Study Report (DOE 1993c). The result was compatible with the conclusions of Fecht et al. (1977) who found elevated gamma activity between 0 - and 2-m (0and $6.5-\mathrm{ft})$ depth. The activity was attributed to a leak from a transfer line located $3.2 \mathrm{~m}(10.5 \mathrm{ft})$ from the borehole.

All of the previous geophysical logging results serve as a baseline against which results collected during FY 1999 can be compared. 
Table 2.1. Previous Logging Results for the Specific Retention Facilities to be Logged in Fiscal Year 1999

\begin{tabular}{|c|c|c|c|}
\hline Facility & Borehole & Previous Logging ${ }^{(a)}$ & $\begin{array}{l}\text { Contaminated Intervais From Most } \\
\text { Recent Log }{ }^{(b)}\end{array}$ \\
\hline \multicolumn{4}{|l|}{ PUREX Facilities } \\
\hline $216-A-2$ crib & 299-E24-53 & $1977,1978,1982$ & $7.3 \cdot 15.2 \mathrm{~m}(24-50 \mathrm{ft})$ \\
\hline 216-A-4 crib & 299-E24-54 & $1977,1978,1982,1987$ & $6.1-12.2 \mathrm{~m}(20-40 \mathrm{ft})$ \\
\hline $216-A-7$ & 299-E25-54 & $1978,1984,1986$ & $0-12.2 \mathrm{~m}(0-40 \mathrm{ft})$ \\
\hline 216-A-18 trench & 299-E25-10 & 1978 & Near background \\
\hline \multicolumn{4}{|c|}{ BC Controlled Area Facilities } \\
\hline 216-B-14 crib & 299-E13-1 & $1977,1978,1985,1987,1993$ & $3-61 \mathrm{~m}(10-200 \mathrm{ft})$ (intermittent) \\
\hline 216-B-15 crib & 299-E13-2 & $1977,1978,1985,1987$ & $0-22 \mathrm{~m}(0-72 \mathrm{ft})$ \\
\hline 216-B-16 crib & $\begin{array}{l}299-E 13-3 \\
299-E 13-21\end{array}$ & $\begin{array}{l}1977,1978,1985,1987 \\
1977,1978,1985,1987\end{array}$ & $\begin{array}{l}3-22.9 \mathrm{~m}(10-75 \mathrm{ft}) \\
0-94.5 \mathrm{~m}(0-310 \mathrm{ft})\end{array}$ \\
\hline 216-B-17 crib & 299-E13-4 & $1977,1978,1985,1987$ & $3-22.9 \mathrm{~m}(10-75 \mathrm{ft})$ \\
\hline 216-B-18 crib & 299-E13-5 & $1977,1978,1985,1993$ & $5.2-30.2 \mathrm{~m}(17-99 \mathrm{ft})$ \\
\hline 216-B-19 crib & 299-E13-6 & $1977,1978,1985,1987$ & $\begin{array}{l}3-18.3 \mathrm{~m}(10-60 \mathrm{ft}) \\
95.1-96.3 \mathrm{~m}(312-316)\end{array}$ \\
\hline 216-B-23 trench & 299-E13-55 & 1984,1987 & $4.6-13.1 \mathrm{~m}(15-43 \mathrm{ft})$ \\
\hline 216-B-25 trench & 299-E13-56 & 1984,1987 & $3-10.7 \mathrm{~m}(10-35 \mathrm{ft})$ \\
\hline 216-B-26 trench & 299-E13-12 & $1977,1978,1984,1987$ & $101.8-104.5 \mathrm{~m}(334-343 \mathrm{ft})$ \\
\hline 216-B-27 trench & 299-E13-57 & 1984,1987 & $3-13.7 \mathrm{~m}(10-45 \mathrm{ft})$ \\
\hline 216-B-30 trench & 299-E13-52 & 1987 & $0-27.4 \mathrm{~m}(0-90 \mathrm{ft})$ \\
\hline 216-B-31 trench & 299-E13-58 & 1984,1987 & $6.1-14.9 \mathrm{~m}(20-49 \mathrm{ft})$ \\
\hline 216-B-32 trench & 299-E13-59 & 1984,1987 & $6.1-13.4 \mathrm{~m}(20-44 \mathrm{ft})$ \\
\hline 216-B-33 trench & 299-E13-60 & 1984,1987 & $4.6-13.7 \mathrm{~m}(15-45 \mathrm{ft})$ \\
\hline 216-B-52 trench & 299-E13-54 & 1984,1987 & $3-13.7 \mathrm{~m}(10-45 \mathrm{ft})$ \\
\hline $\begin{array}{l}\text { 216-B-53A } \\
\text { trench }\end{array}$ & 299-E13-61 & 1984,1987 & $4.3-9.1 \mathrm{~m}(14-30 \mathrm{ft})$ \\
\hline 216-B-58 trench & 299-E13-16 & 1984,1987 & No contamination \\
\hline \multicolumn{4}{|l|}{ BX Trenches } \\
\hline 216-B-35 trench & 299-E33-286 & 1984,1987 & $6.1-17.7 \mathrm{~m}(20-58 \mathrm{ft})$ \\
\hline 216-B-37 trench & $\begin{array}{l}299-E 33-287 \\
299-E 33-288\end{array}$ & $\begin{array}{l}1984,1987 \\
1984,1987\end{array}$ & $\begin{array}{l}0-15.2 \mathrm{~m}(0-50 \mathrm{ft}) \\
0-15.2 \mathrm{~m}(0-50 \mathrm{ft})\end{array}$ \\
\hline 216-B-38 crib & $\begin{array}{l}\text { 299-E33-289 } \\
\text { 299-E33-290 }\end{array}$ & $\begin{array}{l}1984,1987 \\
1984,1987,1993\end{array}$ & $\begin{array}{l}0-15.2 \mathrm{~m}(0-50 \mathrm{ft}) \\
0-15.2 \mathrm{~m}(0-50 \mathrm{ft})\end{array}$ \\
\hline 216-B-41 trench & 299-E33-8 & 1977,1978 & $7.9-18.9 \mathrm{~m}(26-62 \mathrm{ft})$ \\
\hline $216-B-42$ trench & 299-E33-10 & 1978 & $\begin{array}{l}6.1-11.6 \mathrm{~m}(20-38 \mathrm{ft}) \\
86.6-87.8 \mathrm{~m}(284-288 \mathrm{ft})\end{array}$ \\
\hline \multicolumn{4}{|c|}{ Semiworks Facilities } \\
\hline $216-C-5$ crib & 299-E24-8 & 1977 & $85.3-92 \mathrm{~m}(280-302 \mathrm{ft})$ \\
\hline \multicolumn{4}{|c|}{$\begin{array}{l}\text { (a) Sources of previous logging results are } 1977=\text { Fecht et al. (1977); } 1978=\text { Additon et al. (1978a 1978b); } \\
1993=\text { Brodeur et al. (1993); all other dates are the dates of unpublished logs on file in the PNNL geophysical } \\
\text { logging database. } \\
\text { (b) Contaminated intervals are given as the vertical interval in the borehole where gamma-ray emitting contamination } \\
\text { was noted. }\end{array}$} \\
\hline
\end{tabular}




\subsection{Facility Description}

This section presents brief descriptions of the specific retention facilities to be monitored. More detailed descriptions can be found in DOE (1993a, 1993b, and 1993c). Appendix A includes as-built diagrams showing construction details of each facility and inventories of contaminants in effluent disposed to each facility.

\subsection{PUREX Facilities (216-A-2 Crib, 216-A-4 Crib, 216-A-7 Crib, and 216-A-18 Trench)}

The 216-A-2 and 216-A-4 specific retention cribs are located $80 \mathrm{~m}(260 \mathrm{ft})$ south of the 202-A (PUREX) Building and are approximately $46 \mathrm{~m}$ (140 ft) apart. The 216-A-2 crib was active between January 1956 and January 1963. During this time, it received 230,000 L (61,000 gal) of low salt, neutral/basic waste (Maxfield 1979). The waste was organic wastes, containing normal paraffin hydrocarbons and tributyl phosphate from the 202-A building (DOE 1993a).

The 216-A-4 crib was active from December 1955 to December 1958 when it received $6,210,000 \mathrm{~L}$ (1,640,000 gal) of low salt, neutral/basic waste. The waste was laboratory cell drainage from the 202-A building and stack drainage from the 291-A-1 stack. Both the 216-A-2 and 216-A-4 cribs were deactivated by removing a portion of, or by blanking, the effluent pipelines after reaching specific retention capacity.

The 216-A-7 crib is located inside the 200 East Area perimeter fence extension, $100-\mathrm{m}$ ( $300-\mathrm{ft})$ east of the 241-A tank farm. The 216-A-7 crib was active between November 1955 and November 1966 when it received $326,000 \mathrm{~L}(86,129 \mathrm{gal})$ of low salt neutral/basic waste. From November 1955 to July 1959 the crib received catch tank overflow waste, sump waste, and pump pit drainage from the 241-A-152 diversion box. From July 1959 to November 1966 it received the catch tank overflow waste and pump pit drainage from the same diversion box. The crib received tributyl phosphate-kerosene organic waste from the 202-A building in November 1966. The crib was deactivated by blanking off the inflow pipeline from the 241-A-152 diversion box (DOE 1993a).

The 216-A-18 trench is located 150-m (492-ft) east of 241-AZ tank farm outside of the 200 East perimeter fence. The trench was originally intended to be a crib; however, the crib was never built. The specific retention trench received $488,000 \mathrm{~L}$ ( 128,900 gal) of depleted uranium waste from the cold startup run at 202-A building (DOE 1993a) from November 1955 to January 1956. The trench was deactivated by removing the aboveground piping and backfilling after specific retention capacity was reached.

\subsection{BC Controlled Area Cribs (216-B-14 through -19)}

The 216-B-14 through - 19 cribs are located in the BC Controlled Area south of the 200 East Area. The cribs operated from January 1956 to December 1957, and each received between $3,400,000$ to 
$8,700,000 \mathrm{~L}$ of effluent. The complete operating history for each crib is given in DOE (1993b). The cribs received high salt, neutral/basic scavenged tributyl phosphate waste from the 221-U (U-Plant) building. According to DOE (1993b) and Maxfield (1979), the BC Controlled Area cribs were deactivated by valving out the feed pipes to the cribs after specific retention capacity was reached. However, comparing the volume defined by the crib dimensions, and the thickness of the vadose zone with the volume of disposed effluent, indicates the amount of effluent disposed to the cribs exceeded specific retention. The wooden bases of the cribs are considered a hazard because they may collapse (DOE 1993b).

\subsection{BC Controlled Area Trenches (216-B-20 through -34, -52, -53A, -53B, -54 , and -58)}

The 216-B-20 through -34 and the 216-B-52 -53A, -53B, -54 and -58 trenches are located in the BC Controlled Area south of the 200 East Area. The 216-B-20 through -34 and -52 trenches received high salt, neutral/basic scavenged tributyl phosphate waste from the 221-U building. The 216-B-53A, $-53 \mathrm{~B}$, -54 , and -58 trenches received neutral/basic wastes from the Plutonium Recycle Test Reactor in the 300 Area. Each trench was active for 1 to 3 months between October 1956 and January 1958 with the exception of 216-B-58 trench, which was active from November 1965 to June 1967.

The $\mathrm{BC}$ trenches were deactivated by removing the above ground piping that connects each trench to the transfer line. Deactivated trenches were backfilled with the original excavated material. In 1969, the trenches were covered with $15 \mathrm{~cm}$ (6 in.) of gravel (DOE 1993b). The wooden bases of the trenches are considered a hazard because they may collapse (DOE 1993b).

\subsection{BX Trenches (216-B-35 through -42)}

The 216-B-35 through -42 trenches are located about $60-\mathrm{m}(200-\mathrm{ft})$ west of the $241-\mathrm{BX}$ tank farm. The 216-B-37 trench received first cycle bottoms from the 242-B waste evaporator. The 216-B-42 trench received high salt, neutral/basic scavenged tributyl phosphate supernatant waste from the $221-\mathrm{U}$ building. All other BX trenches received high salt, neutral/basic, first cycle supernatant waste from the 221-B building. The trenches operated for 1 to 2 months each between February 1954 and February 1955. The trenches were deactivated by removing above ground piping after reaching specific retention capacity.

\subsection{6-C-5 Crib}

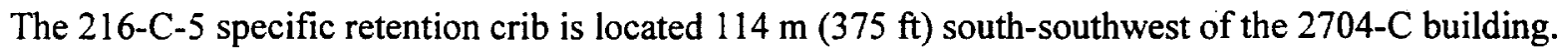
Between March and June 1955, the 216-C-5 crib received 37,000 L (10,000 gal) of high salt waste, which was high in sodium, and cold-run waste, which was saline solutions, from the 201-C process building. The site was deactivated by valving out the effluent pipeline and overing the crib with successive layers of sand, 10-mil-plastic sheeting, sand, and gravel. In April 1992, the 216-C-5 crib was backfilled with ash and downgraded to an underground radioactive material area (DOE 1993c). 


\subsection{Geologic Setting of the 200 East Specific Retention Facilities}

This section briefly describes the hydrogeologic setting of the vadose zone beneath the facilities scheduled for FY 1999 vadose zone monitoring. Delaney et al. (1991) and DOE (1988) describe a more regional geologic setting of the Pasco Basin and the Hanford Site. Also, Tallman et al. (1979) and, more recently, Lindsey (1992) have described the geology of the 200 East Area. The reader is referred to those publications for details of the regional geology. Figure 4.1 shows a generalized stratigraphy for the 200 East Area.

The geology of the 200 East Area consists of the Elephant Mountain Member of the Saddle Mountains Basalt, Columbia River Basalt Group overlain locally by the Ringold Formation, or the Hanford formation.

The Elephant Mountain Member of the Saddle Mountains Basalt is medium- to fine-grained tholeiitic basalt with abundant microphenocrysts of plagioclase (DOE 1988). The Elephant Mountain Member has been dated by K/Ar methods to be about 10.5 million years old (McKee et al. 1977) and consists of two flows beneath the 200 East Area.

The Ringold Formation consists of continental fluvial and lacustrine sediments deposited by the ancestral Columbia and Clearwater-Salmon Rivers between about 8.5 and 3.4 million years ago. The Ringold formation consists of semi-indurated clay, silt, pedogenically altered sediment, fine- to coarsegrained sand, and granule to cobble gravel. The lower half of the Ringold Formation is the Wooded Island Member and contains five separate stratigraphic sequences dominated by fluvial gravels. These are noted as Ringold gravel units A, B, C, D, and E (from oldest to youngest) (Lindsey 1992). These gravels are separated by fine-grained deposits typical of overbank and lacustrine facies (Lindsey 1992). The lowermost of the fine-grained sequences is designated the lower mud unit. Only the Ringold Formation gravel units $A$ and $E$ and the lower mud unit are present under the 200 East Area, and these are not present everywhere. The Ringold Formation is not present in the northern and northeastern parts of the 200 East Area (Lindsey 1992) beneath the BX trenches and the 216-A-7 and -18 crib and trench. It also may be missing from the eastern part of the area.

The Hanford formation is the informal name given to all cataclysmic flood deposits of the Pleistocene Epoch. The Hanford formation was deposited between 1 million years ago and 13,000 years ago. The Hanford formation is present throughout the Hanford Site. It is thickest in the vicinity of 200 West and 200 East Areas where it is up to 65-m (213-ft) thick.

The Hanford formation consists of pebble- to boulder-gravel, fine- to coarse-grained sand, and silt- to clayey-silt. These deposits are divided into three facies: 1) gravel-dominated, 2) sand-dominated, and 3) silt-dominated. These same facies are referred to as coarse-grained deposits, plane-laminated sand facies, and rhythmite facies respectively in Bjornstad et al. (1987). The rhythmites also are referred to as the Touchet Beds. 
Gravel-dominated Facies. This facies generally consists of coarse-grained basaltic sand and granule to boulder gravel. These deposits display an open framework texture, massive bedding, plane to low-angle bedding, and large-scale planar cross bedding in outcrop. The gravel-dominated facies were deposited by high-energy floodwaters in or immediately adjacent to the main cataclysmic flood channelways. Graveldominated facies comprise the upper and lower gravel-dominated sequences denoted Hug and Hlg of the Hanford formation (see Figure 4.1).

Sand-dominated Facies. This facies consists of fine- to coarse-grained sand and granule gravel displaying plane lamination and bedding and less commonly plane bedding and channel-fill sequences in outcrop. These sands may contain small pebbles and rip-up clasts in addition to pebble-gravel interbeds and silty interbeds less than $1-\mathrm{m}(3-\mathrm{ft})$ thick. The silt content of these sands is variable, but where it is low a well-sorted and open framework texture is common. These sands typically are basaltic, commonly being referred to as black, gray, or salt-and-pepper sands. The laminated sand facies was deposited adjacent to main flood channelways during the waning stages of flooding. The facies is transitional between the graveldominated facies and the rhythmite facies. The sand-dominated facies comprise the sand-dominated sequence denoted $\mathrm{Hs}$ in the Hanford formation (see Figure 4.1).

Silt-dominated Facies. This facies consists of thinly bedded, plane laminated and ripple cross-laminated silt and fine- to coarse-grained sand that commonly display normally graded rhythmites a few centimeters to

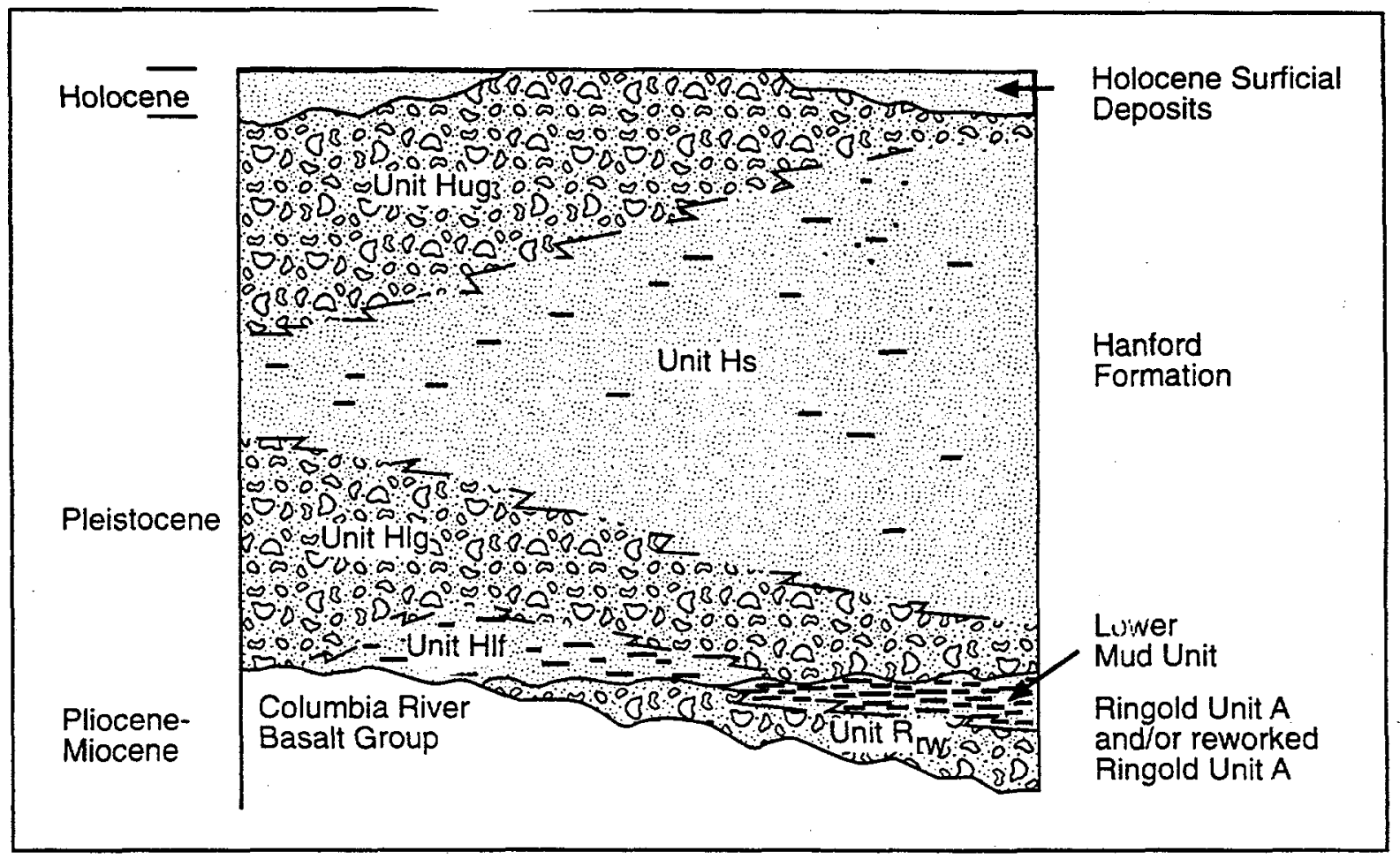

G99050125.3

Figure 4.1. Generalized Stratigraphy for the 200 East Area. Not all units shown are present beneath all specific retention facilities to be logged in fiscal year 1999 (modified from Lindsey and Reynolds 1998). 
several tens of centimeters thick (Myers et al. 1979; Bjornstad et al. 1987; DOE 1988). Locally clay-rich beds occur in this facies. These sediments were deposited under slack water conditions and in back-flooded areas (DOE 1988). The silt-dominated facies comprises most of the relatively thin sequence near the base of the Hanford formation denoted as Hlf in this report (see Figure 4.1).

\subsection{Geology of the 216-A-2 and 216-A-4 Cribs}

The 216-A-2 and 216-A-4 cribs lie within the PUREX security fence and south of the PUREX plant. Lindberg (1997) described the vadose zone beneath these cribs and the description of the vadose zone geology beneath the 216-A-2 and 216-A-4 cribs presented here is summarized from that source.

The general stratigraphy of the vadose zone in the vicinity of the 216-A-2 and -4 cribs includes (from upper to lower)

- a discontinuous layer of Holocene eolian sediment

- approximately $80 \mathrm{~m}$ ( $260 \mathrm{ft}$ ) of cataclysmic glaciofluvial deposits of the Hanford formation consisting predominantly of sands (Hs sequence), but with substantial amounts of gravel in the upper and lower beds

- the fluvial Ringold Formation.

The vadose zone in the vicinity of the $216-\mathrm{A}-2$ and $216-\mathrm{A}-4$ cribs is about $99-\mathrm{m}$ (325-ft) thick. Most of the vadose zone beneath these facilities is comprised of the Hanford formation Hs unit. However, the lowermost meters (approximately $<3 \mathrm{~m}[10 \mathrm{ft}]$ ) may be the Ringold unit $\mathrm{E}$ gravels. No groundwater wells are near the cribs, and the area is one where the lowermost vadose zone is Ringold unit $E$ to the east and Hanford formation Hlg sequence to the west.

The liquid effluent study (WHC 1990) estimated contaminant and moisture migration rates through the vadose zone beneath the 216-A-37-1 crib (approximately $365-\mathrm{m}$ [1200-ft] east of the $216-\mathrm{A}-4 \mathrm{crib}$ where the vadose zone is approximately $84-\mathrm{m}$ [275- $\mathrm{ft}]$ thick). Those estimates indicate that during operation of the $216-\mathrm{A}-37-1 \mathrm{crib}$, travel time of waste water through the vadose zone to the water table was on the order of 8 to 9 months. Maximum depth of penetration for the relatively small quantities of cesium-137 and strontium-90 (<1 Ci) beneath the $216-\mathrm{A}-37-1$ crib was about $40 \mathrm{~m}(130 \mathrm{ft})$.

\subsection{Geology of the 216-A-7 Crib and the 216-A-18 Trench}

The 216-A-7 crib and 216-A-18 trench lie within about 150-m (490-ft) east and northeast of the Waste Management Area A-AX. The geology of the vadose zone in the Waste Management Area A-AX area was first described by Price and Fecht (1976a, 1976b) and then by Caggiano and Goodwin (1991). Most recently the geology of Waste Management Area A-AX was summarized by Narbutorskih et al. 
(1996) and by Lindsey and Reynolds (1998). The description of the vadose zone beneath the 216-A-7 crib and 216-A-18 trench is taken from these sources and augmented with more recent examination of archived borehole cuttings.

The vadose zone beneath $216-\mathrm{A}-7 \mathrm{crib}$ and $216-\mathrm{A}-18$ trench is approximately 80 - to $90-\mathrm{m}$ (262- to $295-\mathrm{ft}$ ) thick and is entirely within the Hanford formation. The water table is at about $123-\mathrm{m}$ (403- $\mathrm{ft}$ ) elevation. The water table lies primarily just below a silt-rich sequence of the Hanford formation, the bottom of which occurs between 112 and $123 \mathrm{~m} \mathrm{(367} \mathrm{and} 403 \mathrm{ft}$ ) below ground surface (bgs).

The Hanford formation beneath the 216-A-7 and 21-A-18 facilities consists of up to five clastic sediment sequences distinguished mainly by texture (particle size) and stratigraphic position. These sequences are

- upper gravel sequence (Hug)

- middle sand sequence (Hs)

- lower gravel sequence (Hlg)

- silt-rich sequence (HIf)

- basal gravel unit (Ringold unit $A$ or reworked unit $A\left(R_{r w}\right)$.

The Hug sequence consists predominantly of interbedded sands, gravelly sands, and sandy gravels. Individual beds are up to approximately $15-\mathrm{m}(50-\mathrm{ft})$ thick and generally grade into adjacent beds. Thin silt lenses up to $10-\mathrm{cm}$ (4-in.) thick are common but not abundant. Calcareous zones occur in the Hug sequence and are generally recognized by reaction of hydrochloric acid with the drill cuttings and not by discrete calcareous particles or cement. The silt lenses may have an influence on infiltration but because they probably are not laterally continuous, they will produce only local impediment to vertical flow. The Hug sequence extends to the bottom of the lowest sandy gravel or gravelly sand that overlies a minimum of 6 to $8 \mathrm{~m}$ ( 20 to $25 \mathrm{ft})$ of sand or slightly gravelly sand.

The Hs sequence underlies the Hug sequence and consists of silty sand, sand, and slightly gravelly sand. The Hs sequence ranges in thickness from about 24 to $46 \mathrm{~m}$ ( 78 to $150 \mathrm{ft}$ ) at Waste Management Area A-AX. Individual beds $\geq 9-\mathrm{m}(30-\mathrm{ft})$ thick are common and grade into overlying and underlying beds within the Hs sequence. The sandy beds are salt-and-pepper sands ranging from about $30 \%$ basaltic and $70 \%$ felsic sediment to $70 \%$ basalt and $30 \%$ felsic sediment.

Silt lenses and thinly interbedded silt and sand, which are calcareous in places, are common but are not abundant in the Hs sequence. Calcium carbonate occurs in the Hs sequence as poorly developed cemented zones and nodules in some sandy zones. The amount of calcium carbonate is small and usually less than $1 \mathrm{wt} . \%$. The base of the Hs sequence as defined here is the bottom of the lowermost sand or slightly gravelly sand that is at least $21-\mathrm{m}(70-\mathrm{ft})$ thick. The Hs sequence overlies the lower gravel sequence $(\mathrm{Hlg})$ or the silt-rich sequence $(\mathrm{Hlf})$ if the $\mathrm{Hlg}$ is not present. 
The Hlg sequence consists of up to approximately $18 \mathrm{~m}(60 \mathrm{ft})$ of dominantly gravelly sand with some sandy gravel and gravel. Individual beds are from about $1.5-$ to $14-\mathrm{m}(5-$ to $45-\mathrm{ft})$ thick and generally grade into overlying and underlying beds. Silt lenses and calcareous zones are not common in the Hlg sequence as they are in the overlying units.

The silt-rich unit (Hlf) is present in all but one borehole in the Waste Management Area A-AX area, east of trenches, where it varies in thickness from about 1.2 to $4.6 \mathrm{~m}$ ( 4 to $15 \mathrm{ft}$ ). The Hlf sequence is not present in well 299-E33-10 which monitors and is located west of the 216-B-42 trench. The Hlf sequence consists of silt and sandy silt with lesser amounts of slightly gravelly sandy silt. Available moisture logs show the HIf sequence has higher moisture content than overlying sediments. No perched water has been noted on top of the HIf sequence (Caggiano and Goodwin 1991). However, the water table was higher and nearer to the Hlf sequence in the past, and the current high moisture content may be a remnant of a higher water table.

The Hlf sequence was considered by Lindsey (1992) and Lindsey and Reynolds (1998) to be the Ringold lower mud unit. However, the Hlf sequence occurs above the lower mud unit in well 699-37$47 \mathrm{~A}$, near the southeast corner of 200 East Area, where the Hlf sequence is at about $131-\mathrm{m}$ ( $431-\mathrm{ft})$ elevation. This is $25 \mathrm{~m}(82 \mathrm{ft})$ above the Ringold lower mud unit in that well. In addition, the elevation at which the Hlf occurs beneath Waste Management Area A-AX is 15 to $21 \mathrm{~m}$ (50 to $70 \mathrm{ft}$ ) higher than the elevation of the Ringold lower mud unit in other nearby wells (e.g., 299-E16-1 and 299-E17-6). The HIf sequence is interpreted in this report to be part of the Hanford formation.

The basal gravel unit $\left(R_{r w}\right)$ underlies the Hlf sequence in the area of the 216-A-7 and 216-A-18 facilities. This unit may be reworked Ringold unit A gravels deposited during the Pleistocene by catastrophic floods. The $R_{r w}$ unit is below the water table in the area.

\subsection{Geology of the BC Controlled Area Cribs and Trenches}

All of the boreholes to be logged in the BC Controlled Area were drilled prior to the 1960 s, so only driller's logs are available. However, Lindsey (1992) and DOE (1993b) describe the vadose zone geology beneath the $\mathrm{BC}$ Controlled Area cribs and trenches and the following brief description is taken from them.

Most of the vadose zone beneath the BC Controlled Area consists of the Hanford formation. The water table is at approximately $123-\mathrm{m}(403-\mathrm{ft})$ elevation, which places it approximately within the upper $3 \mathrm{~m}$ (10 ft) of the Ringold unit E (DOE 1993b).

The uppermost unit of the vadose zone at the BC Controlled Area is a variably thin unit (less than about $3 \mathrm{~m}$ [10 ft]) cover of eolian sand and silt. The eolian material has been removed from some of the area during construction of the cribs and trenches. The eolian sediment is underlain by the Hanford formation upper gravel sequence which is $5-$ to $20-\mathrm{m}(16-$ to $65-\mathrm{ft})$ thick in the BC Controlled Area.

The Hanford formation sand sequence is beneath the upper gravel unit. The sandy sequence is the thickest unit in the vadose zone beneath the BC Controlled Area where it varies from 60 to $90 \mathrm{~m}$ (196 to 
$295 \mathrm{ft}$ ). The sand sequence consists of variably cemented coarse-grained sand with minor amounts of silt and clay. Three soil zones or paleosols horizons were identified in the sand sequence in well 299-E17-21 (Reidel et al. 1998). The three horizons represent time intervals when soil development took place and are interpreted to be the tops of three separate Missoula flood deposits. There is some likelihood that the three paleosol are laterally continuous into the BC Controlled Area, but the driller's logs are not detailed enough to identify them.

The Hanford formation lower gravel sequence ( $\mathrm{Hlg})$ is beneath the Hs sequence. The Hlg sequence varies in thickness from about $45 \mathrm{~m}(148 \mathrm{ft})$ in the north-central part of the area to $<10 \mathrm{~m}(33 \mathrm{ft})$ in the southwest part of the area. The Hlg sequence shows a structural high where it is thickest and dips in all directions off of the high with the steepest dip toward the south. Detailed sampling in nearby well 299E17-21 shows the Hlg sequence consists of a clast-supported pebble-cobble gravel with minor amounts of sand in the matrix. The cobbles and pebbles are almost exclusively basalt with no cementation.

The Ringold Unit $\mathrm{E}$ is beneath the Hlg sequence. Unit $\mathrm{E}$ dips toward the northwest under most of the BC Controlled Area. In nearby wells, unit E consists of sandy gravels to gravelly sands with scattered large pebbles and cobbles up to $25 \mathrm{~cm}(10 \mathrm{in}$.) in size. The gravels are well rounded with a sand matrix supporting the cobbles and pebbles. The unit has variable zones of cementation ranging from slight to moderate. The water table is within the Ringold unit $\mathrm{E}$ beneath the $\mathrm{BC}$ Controlled Area.

\subsection{Geology of the BX Trenches}

The vadose zone geology beneath the $\mathrm{BX}$ trenches is somewhat better understood than that beneath the BC Controlled Area because the BX trenches are adjacent to RCRA Waste Management Area B-BX-BY. Waste Management Area B-BX-BY has had several groundwater wells drilled there during the past few years, and the wells have good geologist's logs. The following discussion of the geology of the BX trenches is based Caggiano and Goodwin (1991), Lindsey and Reynolds (1998), and on geologist's logs from wells located just east of the trenches between the trenches and the 241-BX and -BY tank farms.

Most of the vadose zone beneath the BX trenches consists of the Hanford formation. The water table is at approximately $75-\mathrm{m}$ (246- $\mathrm{ft})$ depth, which places it in a gravel sequence overlying the Elephant Mountain basalt.

The Hanford formation upper gravel sequence (Hug) is the upper most unit in the vadose zone at the $\mathrm{BX}$ trenches. The sequence consists of muddy sandy gravel and gravelly sand and varies in thickness from about 14 to $24 \mathrm{~m}$ ( 45 to $80 \mathrm{ft}$ ) in wells to the east of the trenches.

Underlying the Hug is a thick sequence of sand to slightly gravelly sand. The sand sequence is generally more sandy at the bottom and becomes more gravelly toward the top (Caggiano and Goodwin 1991). The Hs is up to approximately $58-\mathrm{m}(190-\mathrm{ft})$ thick and commonly contains lenses of silt and sandy mud; however, these lenses cannot be correlated among boreholes. The Hs contains variable but small amounts of calcium carbonate cementation. 
Beneath the eastern portion of the BX trench area, in borehole.299-E33-21, the Hs sequence is underlain by a fairly thin (6- to 9-m [20- to 30-ft]) layer of coarse sand and gravel (Hlg sequence) which

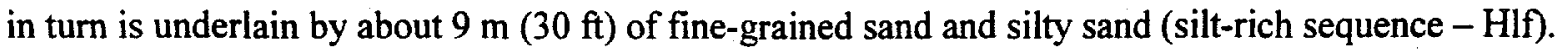
This fine-grained sequence is laminated in places and contains cobble size rip-up clasts. Neither the Hlg nor the Hlf is present immediately west of the trenches in borehole 299-E33-10. West of the trenches the Hs sequence is underlain by a sequence of gravels consisting of muddy sandy gravels to gravelly sand

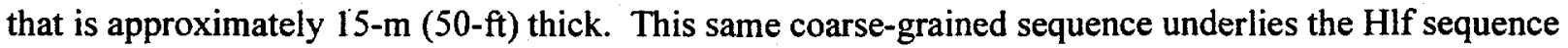
east of the trenches. The water table is within and near the top of the lowest gravel sequence.

\subsection{Geology of the 216-C-5 Crib}

The vadose zone geology beneath the 216-C-5 crib has been described in Lindsey (1992) and DOE (1993c) from which the following brief description is taken.

The vadose zone beneath the $216-\mathrm{C}-5 \mathrm{crib}$ is about $87-\mathrm{m}(285-\mathrm{ft})$ thick. The uppermost sequence at the 216-C-5 crib is a thin sequence of Hanford formation Hug sequence or, locally, recent eolian dune sand. This overlies the Hanford formation Hs sequence that makes up most of the vadose zone in the area. The Hs sequence consists of a heterogeneous mix of sands with minor deposits of the siltdominated facies. Gravel also occurs as single clasts and as interbeds in the sands. The Ringold Formation unit $A$ is beneath the Hs sequence. The water table lies in the upper part of the Ringold Formation gravel unit $\mathrm{A}$.

No perched water has been found beneath the 216-C-5 crib. However, thin, discontinuous, silty lenses in the Hs sequence leaves the potential for local perched water horizons. 


\subsection{Vadose Monitoring}

Thirty boreholes are scheduled to be logged using spectral gamma-ray and neutron moisture methods during May through August 1999. This section describes the specifics of vadose monitoring to be completed at the liquid waste disposal facilities in those months.

\subsection{Objectives of Monitoring}

The vadose monitoring effort has two objectives. First, to describe the current, subsurface distribution of moisture and gamma-emitting contaminants. Second, to document changes in the distribution of subsurface contaminants that have occurred since previous logging events.

\subsection{Constituents of Interest and Detection Limits}

The Proposal for Fiscal Year 1999 Vadose Zone Monitoring and Guidance for Subsequent Years for Liquid Waste Disposal Facilities (Horton et al. 1998) established the constituents of concern for Hanford Site vadose zone monitoring and categorized them into three groups:

- mobile constituents (technetium-99, iodine-129, nitrate, uranium, chromium, carbon tetrachloride, cyanide, and soluble aluminum)

- immobile and/or moderate to long-lived radionuclides (isotopes of plutonium, americium, and cesium)

- moisture (driving force).

The specific constituents of concern for this monitoring project are moisture and the gamma-emitting radionuclides, which include cesium-137, plutonium-239, plutonium-241, uranium-235, and uranium-238 that were disposed of in the facilities. In addition, americium- 241 is included because it is a daughter of plutonium-241. Protactinium-233 is included because it is a measure of the parent isotope neptunium-237, which is a nuclear reaction product of uranium-238 (and a daughter of americium-241). The non-gamma-emitting radionuclides of interest cannot be detected with the tools to be used for this monitoring effort.

The constituents of concern (excluding moisture) that can be detected during this monitoring effort are listed in Table 5.1. Also shown in Table 5.1, is the half-life for each isotope, the energy of the major isotope-specific gamma-ray, the intensity of the major gamma-ray, and the detection limit given the conditions listed in the table. The detection limits in Table 5.1 are for gamma-ray emitting radionuclides in the Hanford subsurface detected through a $0.64-\mathrm{cm}-(0.25$-in-) thick steel casing with a 40 second spectra collection time, a $35 \% \mathrm{HPGe}$ detector, and full-width-at-half-maximum resolution of $2.2 \mathrm{KeV}$ at $1332 \mathrm{KeV}$. The conditions to be used for FY 1999 logging will differ from those conditions listed in Table 5.1. The FY 1999 logging will use a more sensitive, 70\% HPGe detector, except in boreholes with 
high activity that would saturate the $70 \%$ detector. A $10 \%$, shielded, HPGe detector will be used in boreholes with high activity. Also, a logging speed of about $1 \mathrm{ft} / \mathrm{min}$ will be used for an initial scan of the borehole and, if zones of interest are identified, slower logging speeds will be used subsequently. Finally, the casing thickness for each well will be measured in the field by hand-held caliper to determine the exact casing correction that needs to be applied to the results from each borehole. This will ensure that too large a casing correction will not be applied, which might increase detection limits and bias results as smaller than reality. Actual detection limits will be determined for each borehole using the above mentioned, borehole specific input.

Table 5.1. Detectable Radionuclides

\begin{tabular}{|c|c|c|c|c|}
\hline Radionuclide & $\begin{array}{c}\text { Half-Life } \\
(\mathrm{yr})\end{array}$ & $\begin{array}{c}\text { Major Gamma-Ray } \\
(\mathrm{KeV})\end{array}$ & $\begin{array}{c}\text { Gamma-Ray } \\
\text { Intensity } \\
\text { (percent) }\end{array}$ & $\begin{array}{c}\text { Detection } \\
\text { Threshold }^{(a)} \\
(\mathrm{pCi} / \mathrm{g})\end{array}$ \\
\hline Cs- 137 & 30.2 & 661.6 & 84.6 & 0.2 \\
\hline $\mathrm{U}-235$ & $0.7 \times 10^{9}$ & 185.7 & 54.0 & 0.5 \\
\hline U-238 & $4.5 \times 10^{9}$ & 1001.0 & 0.8 & 24. \\
\hline $\begin{array}{l}\mathrm{Pa}-233 \\
(\mathrm{~Np}-237)\end{array}$ & $\begin{array}{l}2.1 \times 10^{6} \\
(\mathrm{~Np}-237)\end{array}$ & 311.9 & 33.7 & 0.5 \\
\hline $\mathrm{Pu}-239$ & 24,000 & 413.7 & 0.00151 & 4950 . \\
\hline $\mathrm{Pu}-241$ & 15.2 & 98.4 & 0.0022 & 26000 . \\
\hline $\mathrm{Am}-241$ & 433 & 59.5 & 36.3 & 40. \\
\hline \multicolumn{5}{|c|}{$\begin{array}{l}\text { (a) Detection threshold for } 0.25 \text {-inch steel casing, } 35 \% \mathrm{HPGe} \text { detector, and } 40 \text { second } \\
\text { sample time. }\end{array}$} \\
\hline
\end{tabular}

Spectral gamma-ray detection of plutonium isotopes is improbable due to high detection limits for the isotopes of plutonium coupled with the relatively small quantities of plutonium discharged to most specific retention facilities. However, the detection of americium-241 may imply the presence of plutonium-241, because americium-241 is not listed in the inventories of contaminants disposed to the facilities. Likewise, the relatively high detection limit for uranium-238 may make its identification unlikely. The detection of protactinium-233, however, might be used to infer uranium-238.

The measurement errors associated with the spectral gamma-ray measurements will be calculated based on counting statistics. Thus they cannot be determined beforehand and will be determined based on the measurements made in the borehole.

In addition to isotope specific activities, gross gamma activity is a parameter of interest. The gross gamma activity will be obtained by summing the intensity of each separate photon energy. The gross gamma logs can be qualitatively compared to previously obtained gross gamma logs to help discern any movement of subsurface contamination. 
A neutron moisture tool will be utilized to determine the percent moisture by volume in the sediments surrounding the boreholes. Moisture within the sediments can be determined within a range from 0.5 to 40 percent.

Factors that affect the moisture measurements are voids behind the casing; presence of grout or bentonite seals; and conditions that vary significantly between the environment encountered in the borehole and the calibration models at which the moisture tool was calibrated. Corrections for casing size (diameter) and thickness will be applied to the raw data to compensate for the effects of casing on the measurements.

\subsection{Monitoring Points (Boreholes)}

Thirty-one boreholes were initially chosen for evaluation for logging at the 200 East Area specific retention facilities. The initial boreholes were chosen based on

- location relative to the facilities

- location relative to subsurface contamination

- availability of historical gamma-ray spectra for comparison

- initial evaluation of well construction.

Each borehole on the initial list was then evaluated for logging quality by reviewing information found in driller's logs, borehole construction reports, as-built diagrams, and documentation of alterations made to the borehole subsequent to its original construction. Based on the results of these evaluations, 30 boreholes were selected for logging (Table 5.2). The locations of the boreholes are shown on the facility maps in Figure 5.1 (216-A-2 and 216-A-4), Figure 5.2 (216-A-7 and 215-A-18), Figure 5.3 (216-B-14 through -19), Figure 5.4 (216-B-20 through -34, -53A, and -58), Figure 5.5 (216-B-35 through -42 ), and Figure 5.6 (216-C-5). Well Construction and Completion Summary reports (as-built diagrams) are in Appendix B of this document for boreholes scheduled to be logged.

Portions of some of the boreholes scheduled for logging have been retrofitted with a grout seal around the borehole casing. Gross gamma-ray and spectral gamma-ray logs made in these boreholes subsequent to the installation of the grout seal have detected zones of contamination. Therefore, the grouted regions in these wells will be logged with the spectral gamma-ray tool. Grouted zones will not be logged with the neutron tool.

\subsection{Pre-logging Field Activities}

Several activities need to be accomplished before geophysical logging can begin. Field operations in preparation for logging will be done by Waste Management Federal Services, Inc., Northwest Operations (WMNW) under Pacific Northwest National Laboratory (PNNL) direction. The following activities must be completed: 
- Because most of the boreholes scheduled for logging have not been visited for several years, all the boreholes to be logged will be swabbed for internal radiation prior to logging. The results will help establish the level of health physics support.

- For wells containing groundwater pumps, the pumps will be removed from wells prior to logging. Pumps will be to be reinstalled after completion of logging.

- Radiation Control Technologist (RCT) support will be needed for the following activities:

- swabbing wells for check of internal contamination

- health physics support to enter and exit the BC Controlled Area

- checking wipes and logging cable between logging events

- deployment of the neutron tool and the americium-beryllium source.

- Coordination with PUREX security and/or operations will be required to monitor boreholes 299-E24-53 and 299-E24-54 at the 216-A-2 and 216-A-4 cribs because these facilities are within the PUREX security fence.

- Boreholes that have not been entered recently must have a completed Field Inspection Report. The report should state information pertinent to the condition of the borehole such as access requirements, casing condition, accessible depth, and nearby obstructions. Information from the Field Inspection Report will be used to determine whether to remove the borehole from the monitoring schedule.

\subsection{Monitoring Methods}

The monitoring methods to be employed are spectral gamma-ray logging and neutron moisture methods.

\subsubsection{Spectral Gamma-Ray Logging}

The Radionuclide Logging System (RLS) will use a 70\% efficient high-purity germanium (HPGe) gamma-ray detector. A winch on the back of the RLS vehicle will move the tool through the borehole for data collection. Detector depth will be monitored and controlled by computer. For future data processing, a multi-channel analyzer and a computer in the RLS vehicle will receive the spectra from the detector and store the data along with the depth from which they were acquired. Boreholes 299-E33-286, -287 , and -289 will be logged with the $10 \%$ HPGe tool because historical logs indicate that contamination adjacent to these boreholes will saturate the $70 \% \mathrm{HPGe}$ tool.

Boreholes will be logged initially at $0.27 \mathrm{~m} / \mathrm{min}(0.9 \mathrm{ft} / \mathrm{min})$, continuous scan over the intervals to be logged. Subsequent analysis of the data from the first log will be used to identify 1) the gamma-ray emitting isotopes adjacent to the borehole; 2 ) the detection limits for each isotope based on counting times, casing thickness and logging tool used; and 3) depths in the borehole where the identified isotopes 
Table 5.2. Wells to be Logged at 200 East Area Specific Retention Facilities

\begin{tabular}{|c|c|c|c|}
\hline Facility & Well Number & Total Depth & Comments \\
\hline \multicolumn{4}{|l|}{ PUREX Facilities } \\
\hline $216-\mathrm{A}-2$ crib & $299-E 24-53$ & $15.2 \mathrm{~m}(50 \mathrm{ft})$ & Borehole is within the PUREX security fence \\
\hline 216-A-4 crib & $299-E 24-54$ & $30.5 \mathrm{~m}(100 \mathrm{ft})$ & $\begin{array}{l}\text { Borehole is within the PUREX security } \\
\text { fence; grout seal } 0-50 \text { and } 100-102 \mathrm{ft}\end{array}$ \\
\hline 216-A-7 crib & 299-E25-54 & $45.1 \mathrm{~m}(148 \mathrm{ft})$ & \\
\hline $216-A-18$ trench & 299-E25-10 & $86 \mathrm{~m}(282 \mathrm{ft})$ & Pump in well \\
\hline \multicolumn{4}{|c|}{ BC Controlled Area Facilities } \\
\hline $216-\mathrm{B}-14 \mathrm{crib}$ & 299-E13-1 & $83 \mathrm{~m}(272 \mathrm{ft})$ & Grouted $0-100 \mathrm{ft}$ \\
\hline 216-B-15 crib & 299-E13-2 & $111.3 \mathrm{~m} \mathrm{(365 \textrm {ft } )}$ & \\
\hline \multirow[t]{2}{*}{ 216-B-16 crib } & $299-\mathrm{E} 13-3$ & $111.3 \mathrm{~m} \mathrm{(365 \textrm {ft } )}$ & Double cased and grout seal $0-140 \mathrm{ft}$ \\
\hline & 299-E13-21 & $103 \mathrm{~m}(338 \mathrm{ft})$ & \\
\hline 216-B-17 crib & 299-E13-4 & $112.5 \mathrm{~m} \mathrm{(369 \textrm {ft } )}$ & Double cased and grout seal $0-100 \mathrm{ft}$ \\
\hline $216-\mathrm{B}-18 \mathrm{crib}$ & $299-E 13-5$ & $111.2 \mathrm{~m}(365 \mathrm{ft})$ & Double cased and grout seal $0-100 \mathrm{ft}$ \\
\hline $216-\mathrm{B}-19 \mathrm{crib}$ & $299-\mathrm{E} 13-6$ & $110.9 \mathrm{~m} \mathrm{(364ft)}$ & Double cased and grout seal $0-100 \mathrm{ft}$ \\
\hline 216-B-23 trench & 299-E13-55 & $15.2 \mathrm{~m}(50 \mathrm{ft})$ & Grout seal $0-20 \mathrm{ft}$ \\
\hline 216-B-25 trench & 299-E13-56 & $15.2 \mathrm{~m}(50 \mathrm{ft})$ & Grout seal $0-20 \mathrm{ft}$ \\
\hline 216-B-26 trench & 299-E13-12 & $111.6 \mathrm{~m} \mathrm{(366 \textrm {ft } )}$ & Double cased and grout seal $0-98 \mathrm{ft}$ \\
\hline 216-B-27 trench & 299-E13-57 & $15.2 \mathrm{~m}(50 \mathrm{ft})$ & Grout seal $0-20 \mathrm{ft}$ \\
\hline 216-B30 trench & 299-E13-52 & $28.6 \mathrm{~m}(94 \mathrm{ft})$ & \\
\hline 216-B-31 trench & $299-E 13-58$ & $15.2 \mathrm{~m}(50 \mathrm{ft})$ & Grout seal $0-20 \mathrm{ft}$ \\
\hline 216-B-32 trench & 299-E13-59 & $15.2 \mathrm{~m}(50 \mathrm{ft})$ & Grout seal $0-20 \mathrm{ft}$ \\
\hline 216-B-33 trench & 299-E13-60 & $15.2 \mathrm{~m}(50 \mathrm{ft})$ & Grout seal $0-20 \mathrm{ft}$ \\
\hline 216-B-52 trench & 299-E13-54 & $15.2 \mathrm{~m}(50 \mathrm{ft})$ & Grout seal $0-20 \mathrm{ft}$ \\
\hline 216-B-53A trench & 299-E13-61 & $15.2 \mathrm{~m}(50 \mathrm{ft})$ & Grout seal $0-20 \mathrm{ft}$ \\
\hline 216-B-58 trench & 299-E13-16 & $112.8 \mathrm{~m} \mathrm{(370ft)}$ & Double cased and grout seal $0-98 \mathrm{ft}$ \\
\hline \multicolumn{4}{|l|}{ BX Trenches } \\
\hline 216-B-35 trench & 299-E33-286 & $15.2 \mathrm{~m}(50 \mathrm{ft})$ & High count rate; grout seal $0-20 \mathrm{ft}$ \\
\hline \multirow[t]{2}{*}{ 216-B-37 trench } & 299-E33-287 & $15.2 \mathrm{~m}(50 \mathrm{ft})$ & High count rate; grout seal $0-20 \mathrm{ft}$ \\
\hline & 299-E33-288 & $15.2 \mathrm{~m}(50 \mathrm{ft})$ & High count rate; grout seal $0-20 \mathrm{ft}$ \\
\hline \multirow[t]{2}{*}{ 216-B-38 trench } & 299-E33-289 & $15.2 \mathrm{~m}(50 \mathrm{ft})$ & Grout seal $0-20 \mathrm{ft}$ \\
\hline & 299-E33-290 & $15.2 \mathrm{~m}(50 \mathrm{ft})$ & Grout seal $0-20 \mathrm{ft}$ \\
\hline 216-B-41 trench & 299-E33-8 & $77.7 \mathrm{~m}(255 \mathrm{ft})$ & Pump in well \\
\hline 216-B-42 trench & 299-E33-10 & $88.4 \mathrm{~m}(290 \mathrm{ft})$ & Grouted $0-122 \mathrm{ft}$; pump in well \\
\hline \multicolumn{4}{|l|}{ C-Plant Facility } \\
\hline $216-\mathrm{C}-5 \mathrm{crib}$ & 299-E24-8 & $116.4 \mathrm{~m}(382 \mathrm{ft})$ & Pump in well \\
\hline
\end{tabular}




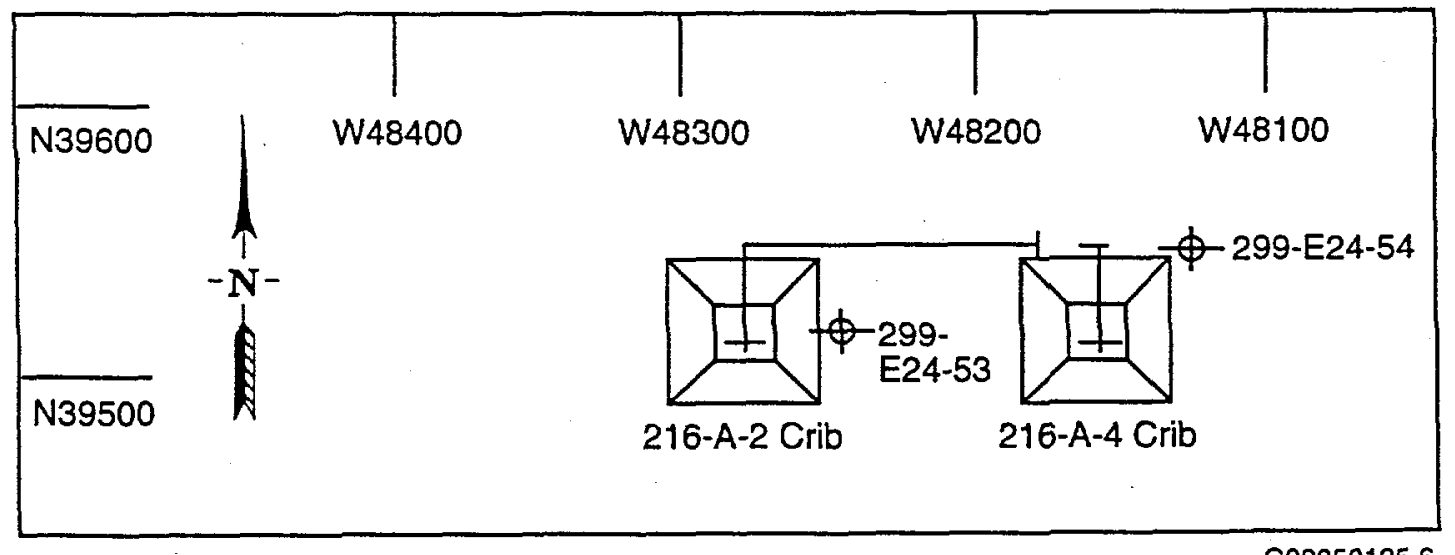

Figure 5.1. Map of the 216-A-2 and 216-A-4 Cribs Showing the Locations of Boreholes to be Monitored in Fiscal Year 1999 (modified from Fecht et al 1977)

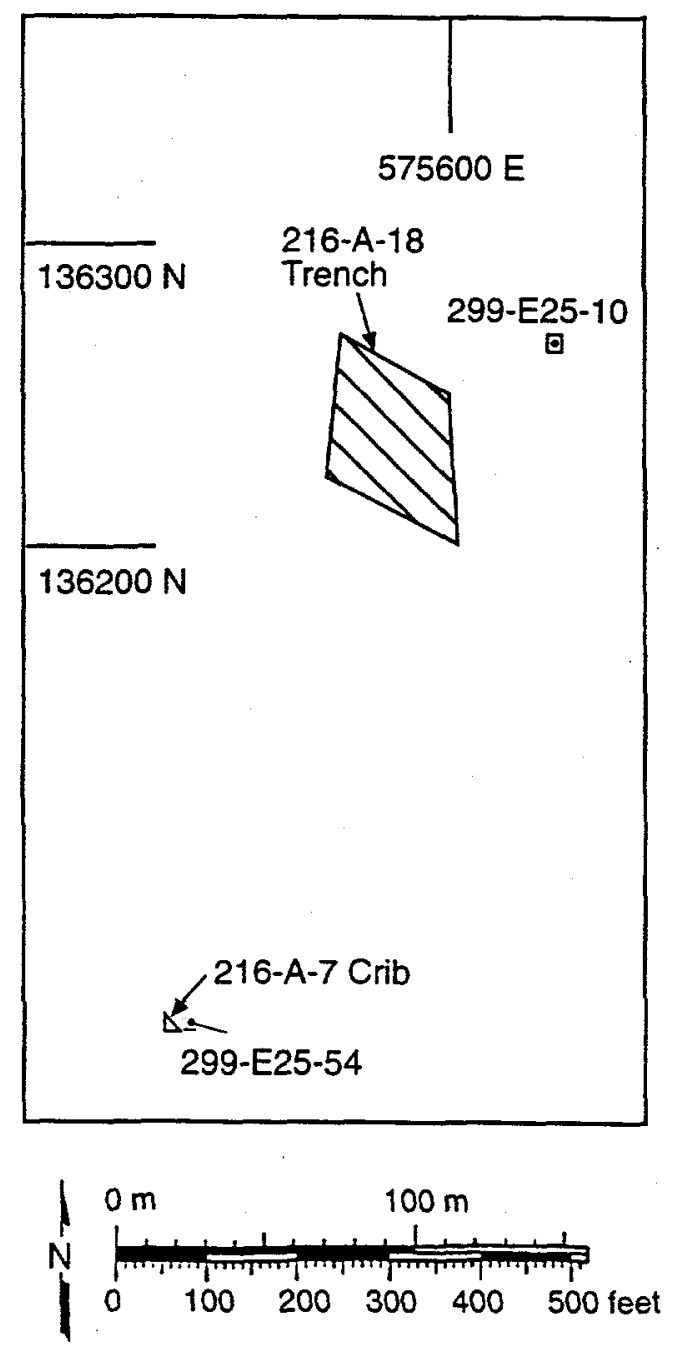

G99050125.1

Figure 5.2. Map of the 216-A-7 Crib and the 216-A-18 Trench Showing the Locations of Boreholes to be Monitored in Fiscal Year 1999 

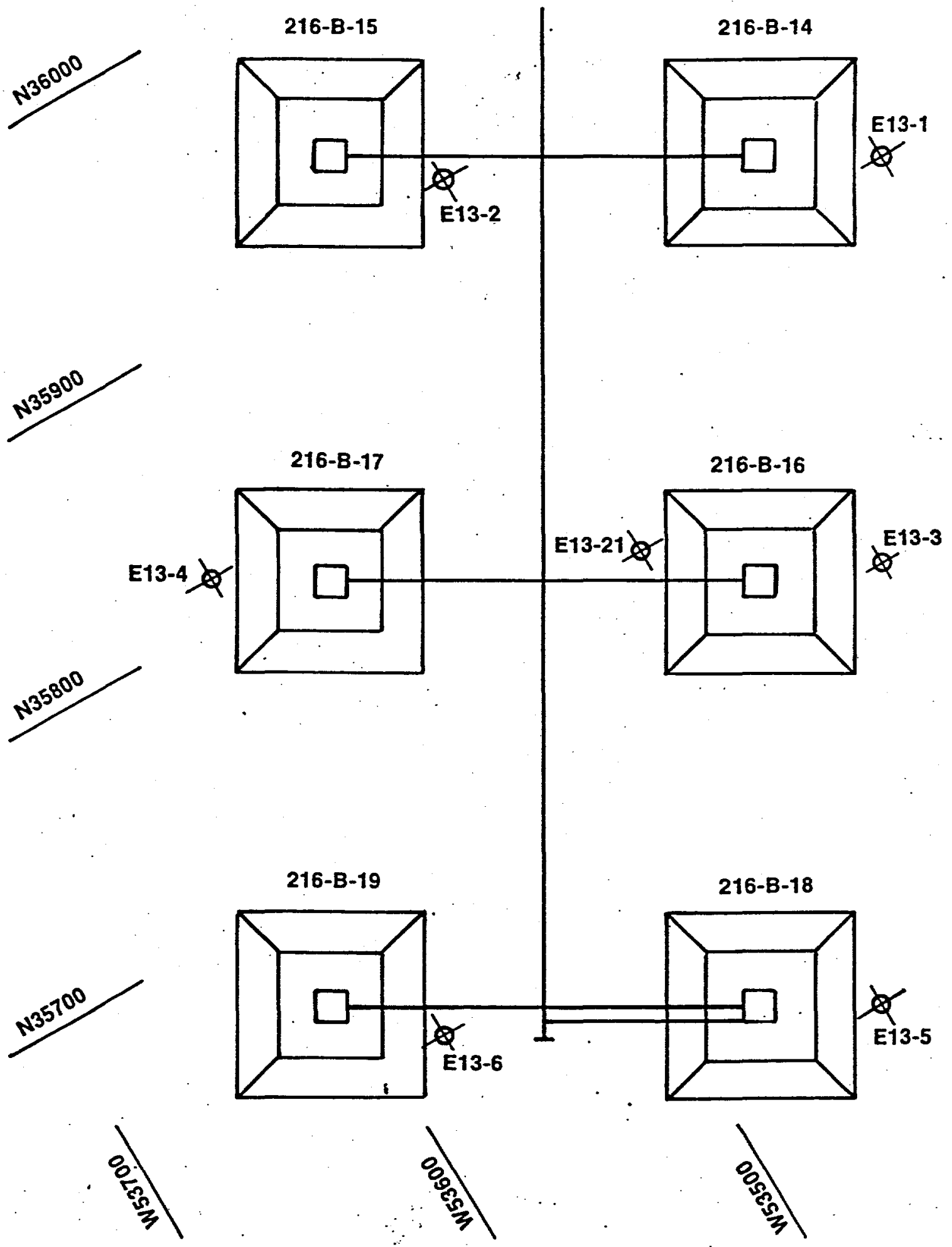

Figure 5.3. Map of the 216-B-14 through -19 Specific Retention Cribs in the BC Controlled Area Showing Locations of Boreholes to be Monitored in Fiscal Year 1999 (from Fecht et al. 1977). All borehole numbers are prefixed with 299 -. 


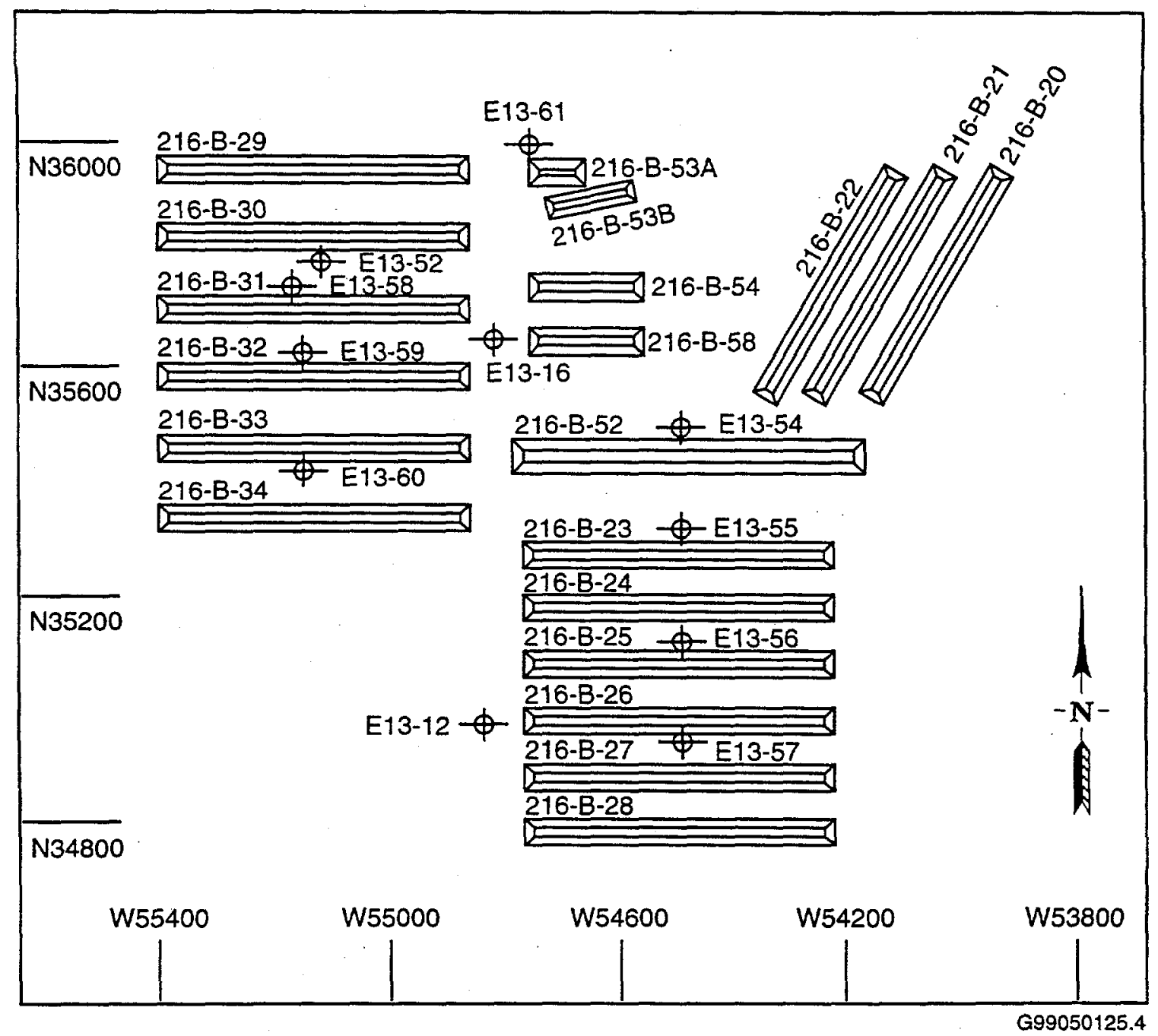

Figure 5.4. Map of the 216-B-20 through -34, -53A, and -58 Specific Retention Trenches in the $\mathrm{BC}$ Controlled Area Showing Locations of Boreholes to be Monitored in Fiscal Year 1999 


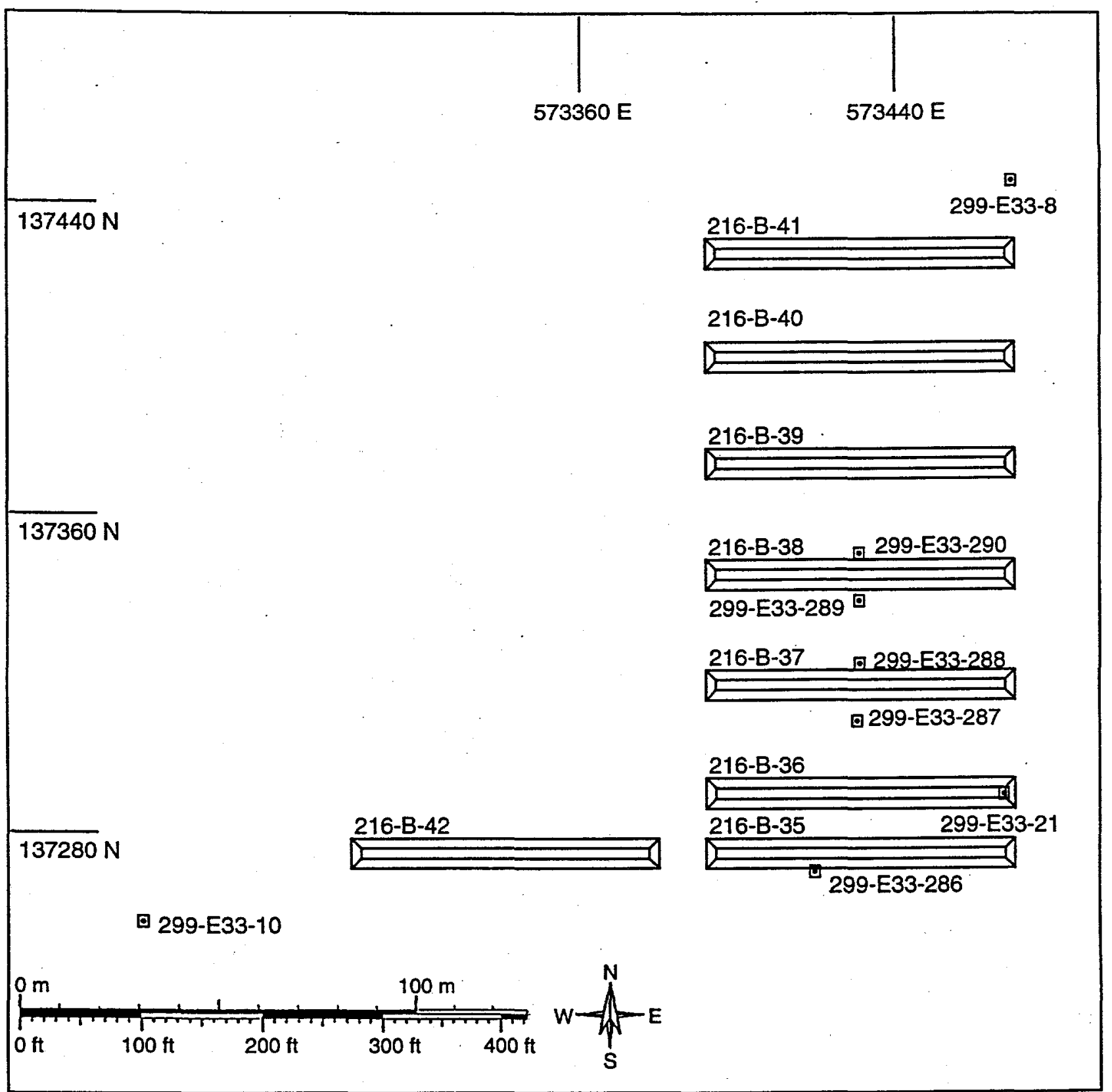

G99050125.2

Figure 5.5. Map of the 216-B-35 through -42 Specific Retention Trenches West of the 241-BX Tank Farm Showing the Locations of Boreholes to be Monitored in Fiscal Year 1999 


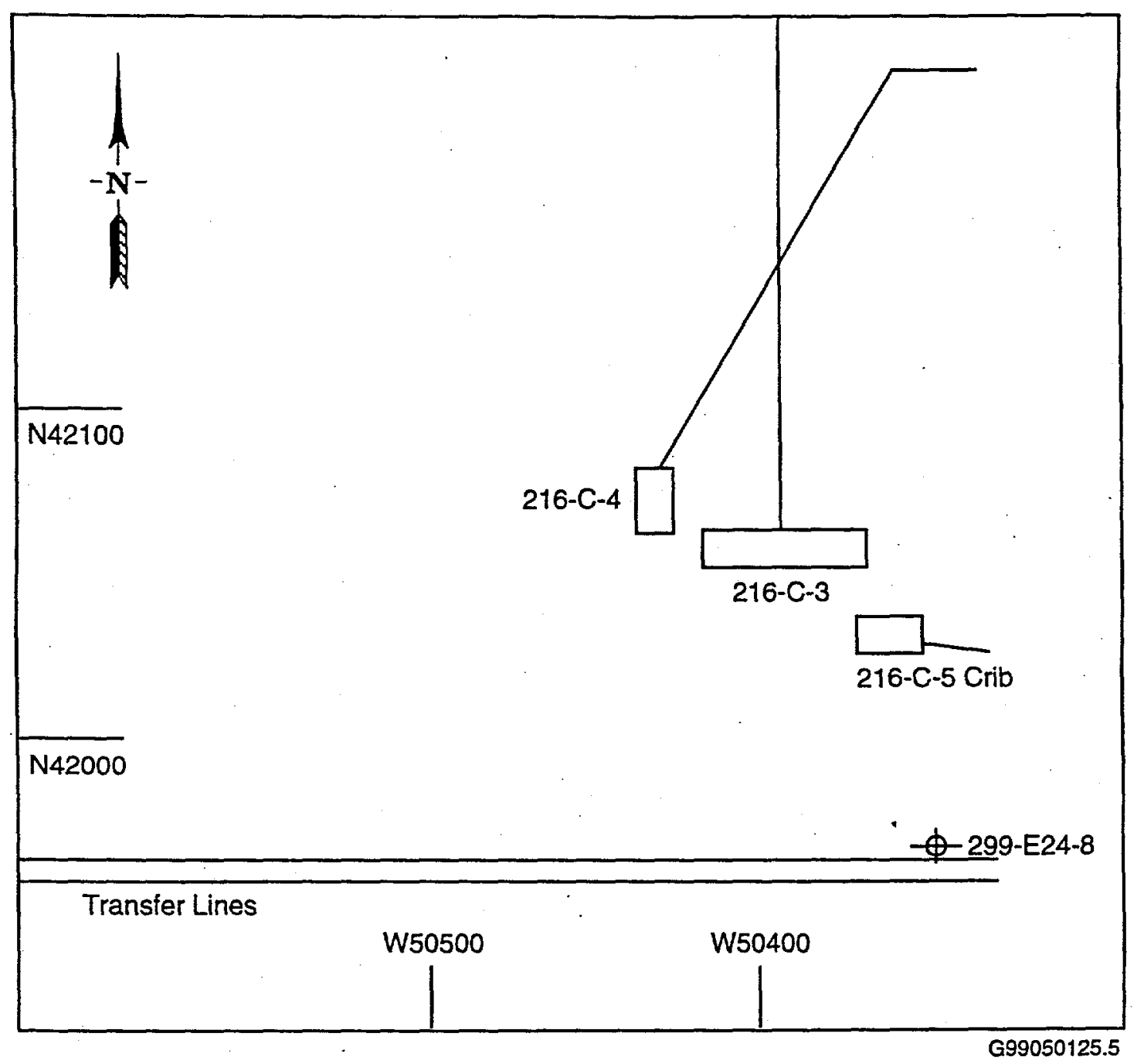

Figure 5.6. Map of the 216-C-5 Specific Retention Crib Showing the Location of the Borehole to be Monitored During Fiscal Year 1999 (modified from Fecht et al. 1977) 
fall below detection limits. These data will provide the basis for a second log to be obtained in zones of interest. The logging speed of the second $\log$ will be based on the isotope of interest and the target minimum detection limit for the borehole construction configuration, so that movement of contamination since the last historical logging event can be determined.

The second $\log$ also will be obtained with the $70 \%$ HPGe detector unless high radionuclide activities require the use of the $10 \%$ efficiency tool. The total depth interval of the second log will be based on the analyst's review of the first log. The time required to relog and the number of zones will be controlled by PNNL, taking into consideration budget, schedule, and defensible resolution of the detection limits and depth of detectable contamination. At the conclusion of the second logging event, the log analyst will conduct data reduction and provide a borehole report. The report will consist of

- the gamma-ray emitting isotopes identified in the borehole

- the detection limits for each isotope based on count times, casing thickness and logging tool used

- the depth in the borehole where the detected isotopes fall below detection limits

- a graphic display of data by depth (borehole log)

- a standard analytical summary report for the individual borehole including results of the long count-time run.

\subsubsection{Detector Calibration}

The HPGe detector used for this logging effort will have a current Calibration Certificate documenting that it has been calibrated according to the methods in Randall (1994). Measurements for the calibration are acquired in the borehole calibration models located east of the 200 West Area. The construction of the models is documented in Stromswold (1994a). Four calibration models are available for calibrating spectral gamma-ray detectors. The models contain varying mixtures of the natural radionuclides potassium, uranium and thorium. The boreholes are uncased, and calibration measurements are made with the borehole air-filled. Corrections for casing thickness are made during data analysis.

\subsubsection{Detector Verification}

Pre- and post-logging calibration/verification will be done for each logging event and the results will be documented on the log header sheet. The measurements will be made by attaching a sealed and unregulated quantity of radioactive material to the outside of the logging probe at a repeatable position: After collecting a spectrum, the field verification assembly will be removed to a remote location and a background spectrum will be collected. The difference between the two spectra represents the contribution from the verification assembly. The field verification spectra will be analyzed during data 
processing to confirm that the equipment performance was within specifications. If calibration/ verification results fall outside the established acceptance criteria, any deficiencies with the detector will be corrected. If necessary, the detector will be recalibrated prior to continued logging. The acceptance criteria are documented in Operational Environmental Monitoring, Attachment D (WMNW 1998).

\subsubsection{Replicate Logging}

A minimum of $3.05 \mathrm{~m}(10 \mathrm{ft})$ in each borehole will be relogged as a replicate analysis. As nearly as practicable, the replicate logging runs will be measured and analyzed in the same manner as associated data. The start and stop depths of the replicate logging will be selected from the response identified on the main log. The replicate logs will be a quality control check on precision and stability of the detector and electronics.

\subsubsection{Neutron Moisture Tool}

The moisture tool employs a 50 mci americium-beryllium neutron source and a helium-3 detector. It is attached and controlled by the logging system in the same manner as described for the HPGe logging tool.

The moisture tool will be operated at a logging speed of $0.305 \mathrm{~m} / \mathrm{min}(1.0 \mathrm{ft} / \mathrm{min})$ at a data-sampling interval of $0.076 \mathrm{~m}(0.25 \mathrm{ft})$. This sampling rate provides high vertical resolution for the measurements. All the selected boreholes will be logged throughout their length unless multiple casing strings are present or if grout seals have been placed around the casing. Intervals with these conditions will not be logged.

At the conclusion of logging, a plot of the moisture percent at each depth will be produced.

\subsubsection{Detector Calibrations}

The neutron moisture detector utilized for the fiscal year 1999 logging will have a current calibration certificate that documents current calibration according to the methods outlined in Meisner (1995) and Meisner et al. (1996). Measurements for the moisture tool calibration are acquired in the moisture calibration tanks located at Neil F. Lampson Inc., Pasco, Washington. The construction of these models is documented in Engleman (1995). The models contain moisture contents (percent by volume) of 5\%, $12 \%$, and $29 \%$ and are constructed with casing configurations for both $15.24-\mathrm{cm}(6-\mathrm{in}$.) and $20.32-\mathrm{cm}$ (8-in.) - diameter casings.

\subsubsection{Detector Verification}

Pre- and post-logging verification will be performed for each logging event and the results will be documented on the Borehole Survey Data Sheet. The verification measurements are made in the shield that carries the source/detector. The field verification results are analyzed to confirm that the moisturelogging tool is performing within specifications. If verification measurements are not within the established acceptance criteria, the deficiencies will be corrected. If necessary, the moisture tool will be recalibrated prior to continuation of logging. 


\subsubsection{Replicate Logging}

Replicate $\log$ runs will be a quality control check of the precision and stability of the detector and associated electronics. A minimum of $3.05 \mathrm{~m}(10 \mathrm{ft})$ in each borehole will be re-logging as a replicate analysis. As near as practical, the replicate logs will be obtained and the data analyzed in the same manner as the initial log run. The interval of the replicate log run will be selected from response identified on the initial log.

\subsection{Data Reduction and Analysis}

\subsubsection{Spectral Gamma Ray Data}

The software titled LGCALC and associated subroutines will be used to read the digital data, analyze the spectrum (locate peaks and correct for background), identify radionuclides, correct for casing thickness, calculate radionuclide activity, sum all channels for gross gamma values, and generate borehole log plots, and analyst's findings and comments. The main LGCALC program and its subroutines were technically reviewed by Stromswold (1994b) for appropriateness, correctness, completeness, and coding accuracy. Stromswold ran the programs with test data and confirmed that the programs operate correctly.

Analysis of each raw survey spectrum will be as follows (Price 1998):

- A check of the gamma-ray energy conversion coefficient of each spectrum will be made by identifying the gamma-ray photo-peaks from the natural radionuclides and adjusting the channel-toenergy conversion coefficient.

- The HPGe spectrum will be scanned for all gamma-ray peaks present and the net area (gross counts less background counts) of each peak will be computed.

- The gamma-ray peaks will be matched with peaks in a processing library to identify the radionuclide and compute the concentration. The library contains the radionuclide names, gamma-ray energies, and gamma-ray intensities.

- Gamma-ray peaks that were not matched in the processing library will be re-examined first by the algorithm and then, if they are still not matched, by the analyst.

- The areas of identified gamma-ray peaks will be corrected for casing thickness and borehole fluid (water or air) and the concentration will be computed. The analyst will input the water depth, borehole size, and casing thickness. Uncertainties from counting statistics will be computed and reported with the radionuclide concentration.

If an identified radionuclide has multiple gamma-rays, the concentration from each gamma-ray in the spectrum will be computed and recorded in a file. The concentration reported in the results file will be the concentration with the lowest uncertainty. 


\subsubsection{Neutron Data}

The gross counts for the neutron spectra will be derived using the software titled "Field" and will be used to prepare the log plot. A transform that was derived during the moisture tool calibration will be used to convert the gross counts to moisture percent by volume. Moisture data will be plotted with suitable scales to produce the log plot. The plot will be produced with standard commercial software. 


\subsection{Quality Assurance and Quality Control}

\subsection{Organization and Responsibilities}

The Applied Geology and Geochemistry Group of PNNL will have primary responsibility for overseeing this monitoring activity. Field work and geophysical logging will be subcontracted to WMNW. Health Physics support will be provided by Waste Management Federal Services of Hanford, Inc. and/or Bechtel Hanford Inc.

\subsection{Data Collection and Data Reduction}

All aspects of data collection and data reduction for this monitoring effort will be governed by the quality assurance requirements in Operational Environmental Monitoring, Section 17.0 (WMNW 1997a), Vadose Zone Neutron Moisture Logging Procedure (WMNW/MAC 1998), and in Quality Assurance Program Plan for Project Hanford Management Contract Work (WMNW 1997b). Specific Standard Operating procedures covering the work are shown in Table 6.1.

Table 6.1. Standards for Operating Procedures

\begin{tabular}{|l|l|}
\hline \multicolumn{1}{|c|}{ Operating Procedure } & \multicolumn{1}{|c|}{ Document Containing Standards } \\
\hline Data acquisition & $\begin{array}{l}\text { Operational Environmental Monitoring, Section 17, } \\
\text { Attachment A (WMNW 1997a); } \\
\text { Vadose Zone Neutron Moisture Logging Procedure } \\
\text { (WMNW/MAC 1998) }\end{array}$ \\
\hline Data storage and security & $\begin{array}{l}\text { Operational Environmental Monitoring, Section 17, } \\
\text { Attachment C (WMNW 1997a) }\end{array}$ \\
\hline Data reduction, verification and reporting & $\begin{array}{l}\text { Operational Environmental Monitoring, Section 18 } \\
\text { (WMNW 1998) }\end{array}$ \\
\hline Quality control and acceptance criteria & $\begin{array}{l}\text { Operational Environmental Monitoring, Section 17, } \\
\text { Attachment D (WMNW 1997a) }\end{array}$ \\
\hline Document control & $\begin{array}{l}\text { Operational Environmental Monitoring, Section 17 } \\
\text { (WMNW 1997a) }\end{array}$ \\
\hline Calibration practices and standards & $\begin{array}{l}\text { Operational Environmental Monitoring, Section 17, } \\
\text { Attachment E (WMNW 1997a) }\end{array}$ \\
\hline Equipment maintenance & $\begin{array}{l}\text { Operational Environmental Monitoring, Section 17 } \\
\text { (WMNW 1997a) }\end{array}$ \\
\hline Qualifications of personnel and training & $\begin{array}{l}\text { Operational Environmental Monitoring, Section 17 } \\
\text { (WMNW 1997a) }\end{array}$ \\
\hline
\end{tabular}

Deviations from documented procedures may be necessary due to field conditions or other unplanned situations. Any deviations will be documented on the $\log$ header and in field notebooks. 


\subsection{Performance and System Audits and Corrective Actions}

All activities addressed by this monitoring plan will be subject to surveillance of project performance and systems adequacy. Surveillance shall be conducted in accordance with appropriate PNNL or WMNW procedures.

Corrective action requests required as a result of surveillance reports shall be documented and managed as required by standard PNNL and WMNW corrective action procedures. Primary responsibilities for corrective action resolution will be assigned to the technical lead. 


\subsection{Data Interpretation and Reporting}

The basic question of whether or not the subsurface distribution of contaminants has changed since they were last measured will be addressed in several ways. First, the logs collected by this monitoring effort will be compared with logs collected during past monitoring efforts. If past spectral gamma-ray logs are available, computer analysis will aid comparison of the past and new logs. The analyst will visually compare historical gross gamma-ray logs with the new logs. Detection limits and analytical errors will be available for the more recent data. Where this information is available for past logs, quantitative or semi-quantitative comparisons may be made. Quantitative comparisons probably will not be able to be made using older data because associated errors, calibration information, and detection limits are not generally available.

Geophysical logs with identified contamination will be compared to subsurface geology to ascertain any geologic controls on contaminant distribution. Where possible, inferences about non-gamma-ray emitting contaminants will be made from the distribution of detected gamma-ray emitting radionuclides. Once the distribution of subsurface contamination is determined, interpretations about the potential impact on groundwater will be made. 


\subsection{Data Management}

The data resulting from this monitoring effort will be assimilated in two ways. First, a hard copy data package containing all Log Header Files, work sheets, control charts, Borehole Survey Data Sheets, and pertinent pages of log notebooks will be assembled and transmitted to PNNL. Logging results will be included in the hard copy data package and will include 1) references to associated electronic data files for both the raw data and the processed data, 2) interpretative data plots of activities or concentrations versus depth for each borehole logged, and 3) summary narratives discussing pertinent activities associated with the logging effort.

Repeat logs (including associated references to electronic files, interpretive plots, and summary narratives) will be included in the data packages as well as all associated calibration and quality control information pertinent to the logging events.

In addition to hard copy data, WMNW will place electronic files of Log Header Files, raw data, processed data, quality control data, and summary narratives in the geophysical logging database at PNNL.

The following document control requirements will be applied to this monitoring effort:

- All data and ensuing results supporting this Monitoring Plan will be maintained in a safe and secure manner such that reconstruction of processed data from raw data, reconstruction of interpretive data from processed data, and reconstruction of interpretations of subsurface contamination will be possible.

- All preprinted forms and logbook entries shall be signed and dated by the person responsible for the activity at the time it was performed. All entries will be made in ink and any corrections will be made such that no information is rendered unreadable.

- The original of all data will be kept by WMNW and copies kept in the PNNL Geophysical Logging Library. 


\subsection{References}

Additon, M. K., K. R. Fecht, T. L. Jones, and G.V. Last. 1978a. Scintillation Probe Profiles 200 East Area Crib Monitoring Wells. RHO-LD-28, Rockwell Hanford Operations, Richland, Washington.

Additon, M. K., K. R. Fecht, T. L. Jones, and G.V. Last. 1978b. Scintillation Probe Profiles 200 West Area Crib Monitoring Wells. RHO-LD-29, Rockwell Hanford Operations, Richland, Washington.

Bjornstad, B. N., K. R. Fecht, and A. M. Tallman. 1987. Quaternary Stratigraphy of the Pasco Basin Area, South-central Washington. RHO-BW-SA-563A, Rockwell Hanford Operations, Richland, Washington.

Brodeur, J. R., R. K. Price, R. D. Wilson, and C. J. Koizumi. 1993. Results of Spectral Gamma-Ray Logging of Select Boreholes for the Aggregate Area Management Study. WHC-SD-EN-TI-021, Westinghouse Hanford Company, Richland, Washington.

Caggiano, J. A. and S. M. Goodwin. 1991. Interim-Status Groundwater Monitoring Plan for the SingleShell Tanks. WHC-SD-EN-AP-012, Rev. 1, Westinghouse Hanford Company, Richland, Washington.

Chamness, M. A. 1986. Fiscal Year 1986 Scintillation Logging Status. 65633-86-107, Rockwell Hanford Operations, Richland, Washington.

Chamness, M. A., R. E. Lewis, S. S. Teel, R. J. Brockman, D. C. Lanigan, and A. W. Pearson. 1992a. PUREX Aggregate Area Management Study Geologic Data Package. WHC-SD-EN-DP-025, Westinghouse Hanford Company, Richland, Washington.

Chamness, M. A., S. M. Goodwin, S. S. Teel, and R. E. Lewis. 1992b. Semi-Works (C-Plant) Aggregate Area Management Study Geologic Data Package. WHC-SD-EN-DP-027, Westinghouse Hanford Company, Richland, Washington.

Delaney, C. D., K. A. Lindsey, and S. P. Reidel. 1991. Geology and Hydrology of the Hanford Site: $A$ Standardized Text for Use in Westinghouse Hanford Company Documents and Reports. WHC-SC-ERTI-003, Westinghouse Hanford Company, Richland, Washington.

DOE. 1988. Consultation Draft, Site Characterization Plan, Reference Repository Location, Hanford Site, Washington. DOE/RW-0164, Department of Energy, Washington, D.C.

DOE. 1993a. PUREX Source Aggregate Area Management Study Report. DOE/RL-92-04, Department of Energy, Richland Operations, Richland, Washington.

DOE. 1993b. B-Plant Source Aggregate Area Management Study Report. DOE/RL-92-05, Department of Energy, Richland Operations, Richland, Washington. 
DOE. 1993c. Semiworks Source Aggregate Area Management Study Report. DOE/RL-92-18, Department of Energy, Richland Operations, Richland, Washington.

Engleman, R. E., R. E. Lewis, D. C. Stromswold, and J. R. Hearst. 1995. Calibration Models for Measuring Moisture in Unsaturated formations by Neutron Logging. PNL-10801, Pacific Northwest Laboratory, Richland, Washington.

Fecht, K. R., G. V. Last, and K. R. Price. 1977. Evaluation of Scintillation Probe Profiles From 200 Area Crib Monitoring Wells. ARH-ST-156, Atlantic Richfield Hanford Company, Richland, Washington.

Horton, D. G., S. P. Reidel, and G. V. Last. 1998. Proposal for Fiscal Year 1999 Vadose Zone Monitoring and Guidance for Subsequent Years for Liquid Waste Disposal Facilities. PNNL-1 1958, Rev. 1, Pacific Northwest National Laboratory, Richland, Washington.

Lindberg, J. W. 1997. Combination RCRA Groundwater Monitoring Plan for the 216-A-10, 216-A-36B, and 216-A-37-1 PUREX Cribs. PNNL-11523, Pacific Northwest National Laboratory, Richland, Washington.

Lindsey, K. A. 1992. Geologic Setting of the 200 East Area; An Update. WHC-SD-EN-TI-012, Rev. 0, Westinghouse Hanford Company, Richland, Washington.

Lindsey, K. A. and K. D. Reynolds. 1998. "Geology and Stratigraphy of the Tank Farms." In, Jones, T. E., R. Khalell, D. A. Meyers, J. W. Shade, and M. I. Wood. A Summary and Evaluation of Hanford Site Tank Farm Subsurface Contamination. HNF-2303, Rev. 0, Lockheed Martin Hanford Corp., Richland, Washington.

Maxfield, H. L. 1979. Handbook 200 Areas Waste Sites. Vol. 1 through 3. RHO-CD-673. Rockwell Hanford Operations, Richland, Washington.

McKee, E. H., D. A. Swanson, and T. L. Wright. 1977. Duration and Volume of Columbia River Basalt Volcanism, Washington, Oregon, and Idaho. Geological Society of America Abstracts with Programs, Vol. 9, p. 463-464.

Meisner, J. E. 1995. Vadose Zone Moisture Measurement Through Steel Casing Evaluation. WHC-SDEN-TI-304, Westinghouse Hanford Company, Richland, Washington.

Meisner, J. E., R. K. Price, and R. R. Randall. 1996. Radionuclide Logging System In-Situ Vadose Zone Moisture Measurement Calibration. WHC-SD-EN-TI-306, Westinghouse Hanford Company, Richland, Washington. 
Myers, C. W., S. M. Price, J. A. Caggiano, M. P. Cochran, W. J. Czimer, N. J. Davidson, R. C. Edwards, K. R. Fecht, G. E. Holmes, M. G. Jones, J. R. Kunk, R. D. Landon, R. K. Ledgerwood, J. T. Lillie, P. E. Long, T. H. Mitchell, E. H. Price, S. P. Reidel, and A. M. Tallman. 1979. Geologic Studies of the Columbia Plateau: A Status Report, RHO-BWI-ST-4, Rockwell Hanford Operations, Richland, Washington.

Narbutovskih, S. M, D. F. Iwatate, M. D. Sweeney, A. L. Ramirez, W. Daily, R. M. Morey, and L. Christensen. 1996. Feasibility of CPT-Deployed Vertical Electrode Array in Single-Shell Tank Farms. WHC-SD-EN-TA-004, Rev. 0, Westinghouse Hanford Company, Richland, Washington.

Price, R.K. 1998. In Situ Spectral Gamma-Ray Survey Results of Selected Boreholes Associated with B-BX-BY Tank Farm Reassessment. Attachment to letter WMNW-9759114, from Waste Management Federal Services, Inc. Northwest Operations to Pacific Northwest National Laboratory.

Price, W. H. and K. R. Fecht. 1976a. Geology of the 24I-A Tank Farm. ARH-LD-127, Atlantic Richfield Hanford Company, Richland, Washington.

Price, W. H. and K. R. Fecht. 1976b. Geology of the 241-AX Tank Farm. ARH-LD-128, Atlantic Richfield Hanford Company, Richland, Washington.

Randall, R. R. 1994. Calibration of the Radionuclide Logging System Germanium Detector. WHC-SDEN-TI-292, Westinghouse Hanford Company, Richland, Washington.

Reidel, S. P., K. D. Reynolds, and D. G. Horton. 1998. Immobilized Low-Activity Waste Site Borehole 299-E17-21. PNNL-1 1957, Pacific Northwest National Laboratory, Richland, Washington.

Stromswold, D .C. 1994a. Calibration Facilities at Hanford for Gamma-Ray and Fission-Neutron Well Logging. PNL-9958, Pacific Northwest Laboratory, Richland, Washington.

Stromswold, D. C. 1994b. Technical Evaluation of Software for Gamma-Ray Logging System. PNL9807, Pacific Northwest National Laboratory, Richland, Washington.

Tallman, A. M., K. R. Fecht, M. C. Marratt, and G. V. Last. 1979. Geology of the Separation Areas, Hanford Site, South-Central Washington. RHO-ST-23, Rockwell Hanford Operations, Richland, Washington.

Teel, S. S., R. E. Lewis, M. A. Chamness, D. C. Lanigan, V. L. McGhan, R. J. Brockman. 1992. B-Plant Aggregate Area Management Study Geologic Data Package. WHC-SD-EN-DP-026, Westinghouse Hanford Company, Richland, Washington.

WHC. 1990. Liquid Effluent Study: Groundwater Characterization Data. WHC-EO-0367, Westinghouse Hanford Operations, Richland, Washington. 
WMNW. 1997a. Operational Environmental Monitoring. WMNW-CM-004, Section 17.0, Geophysical Logging, Waste Management Federal Services Inc., Northwest Operations, Richland, Washington.

WMNW. 1997b. Quality Assurance Program Plan for Project Hanford Management Contract Work, WMNW-QAPP-001, Waste Management Federal Services, Inc., Northwest Operations, Richland, Washington.

WMNW. 1998. Operational Environmental Monitoring. WMNW-CM-004, Section 18.0, Geophysical Log data Analysis. Waste Management Federal Services, Inc., Northwest Operations, Richland, Washington.

WMNW/MAC. 1998. Vadose Zone Neutron Moisture Logging Procedure. WMNW/MAC-ES-PM-001, Rev. 0, Waste Management Federal Services, Inc., Northwest Operations and MacTec-ERS, Richland, Washington.

Wood, V.W. 1958. Index of CPD Crib Building Numbers - Designs of CPD Radioactive Liquid Wastes Disposal Sites, Part II, Z Plant. HW-55176- Part II, General Electric Hanford Atomic Products Operation, Richland, Washington. 


\section{Appendix A}

Facility Construction As-Built Diagrams (from Wood 1958) for 200 East Area Specific Retention Facilities Scheduled for Vadose Zone Monitoring in Fiscal Year 1999 
HW- $55176-P T I$ APPENDIX C-2
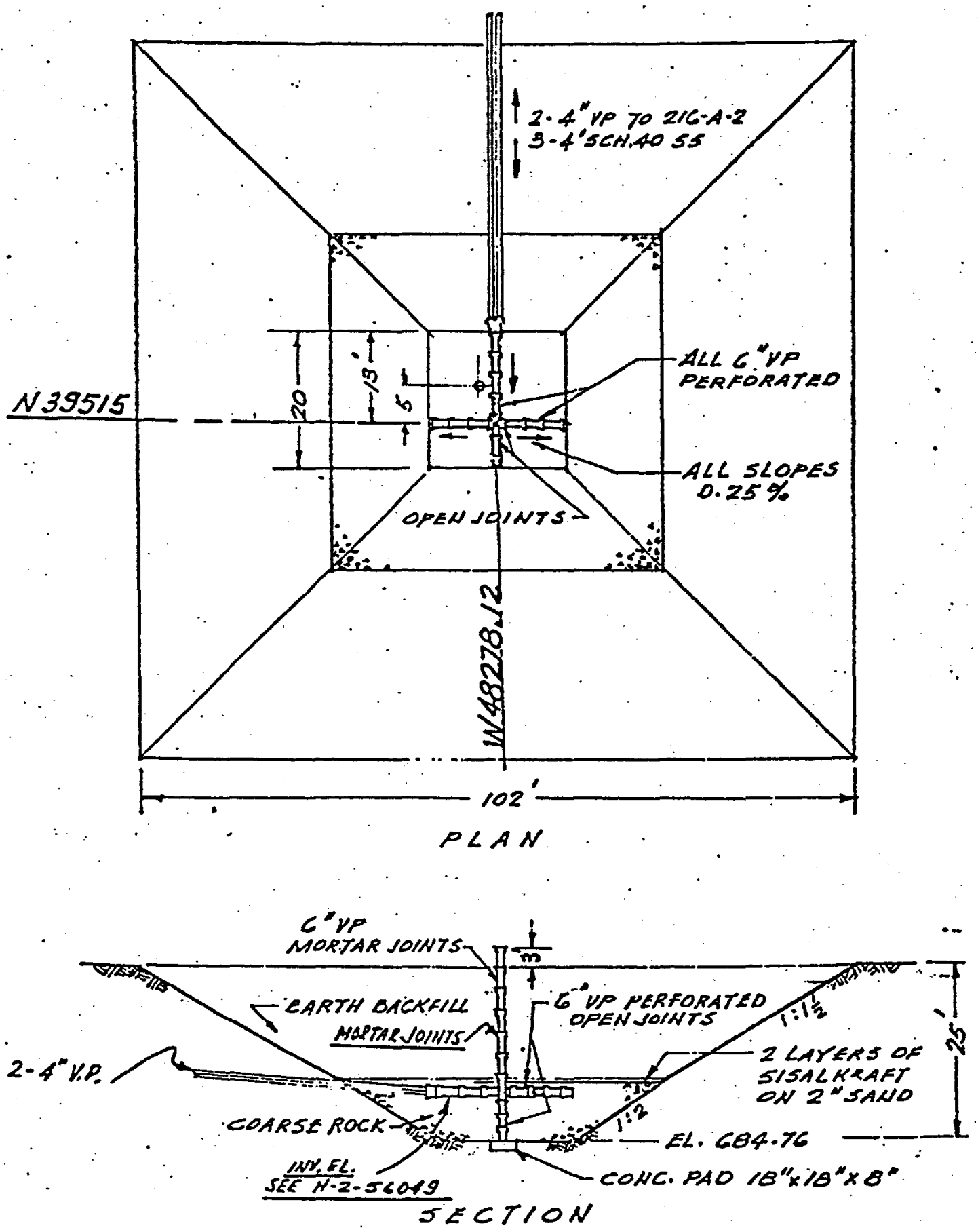

TAKEN FAOM $H-Z-36050$ 


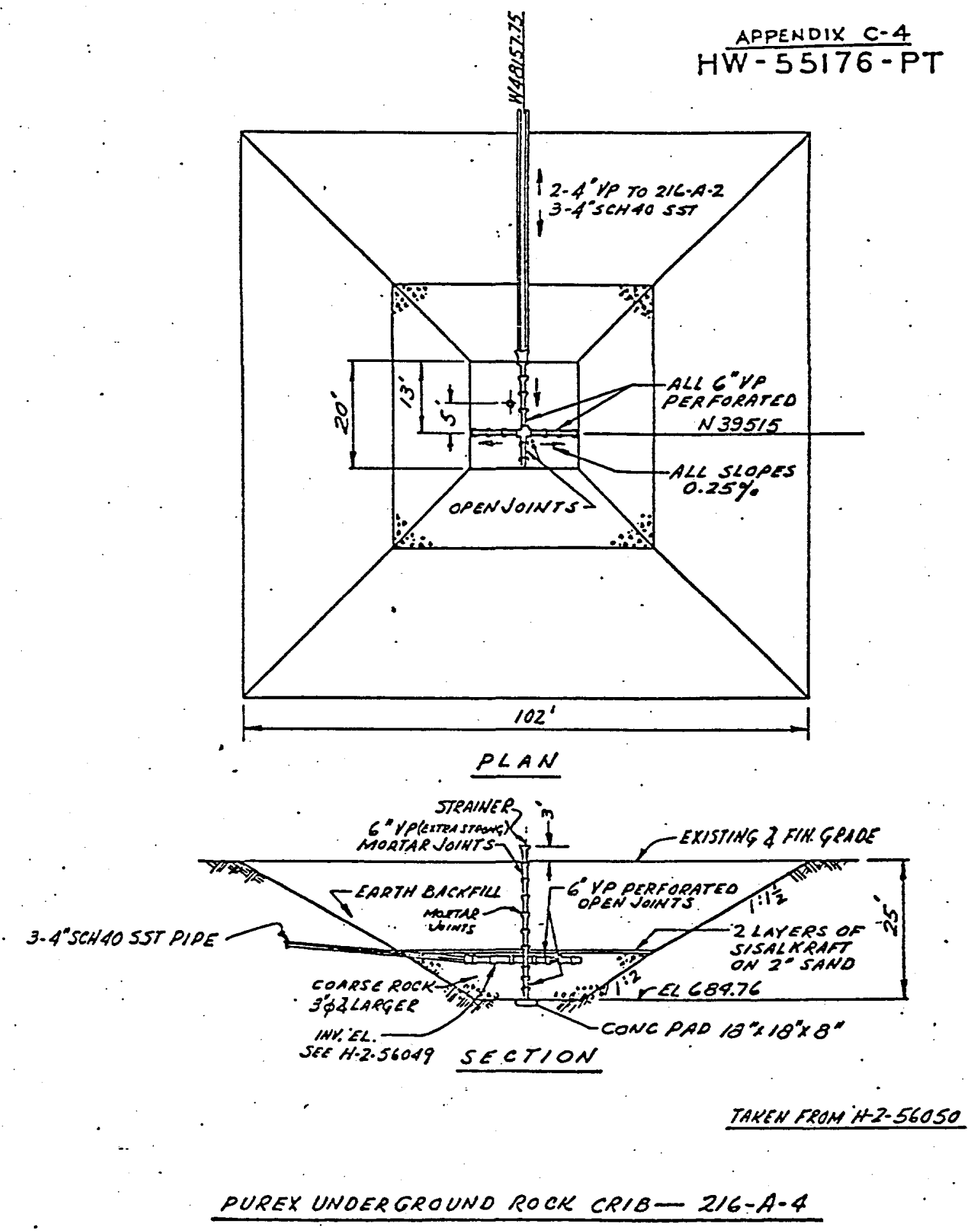




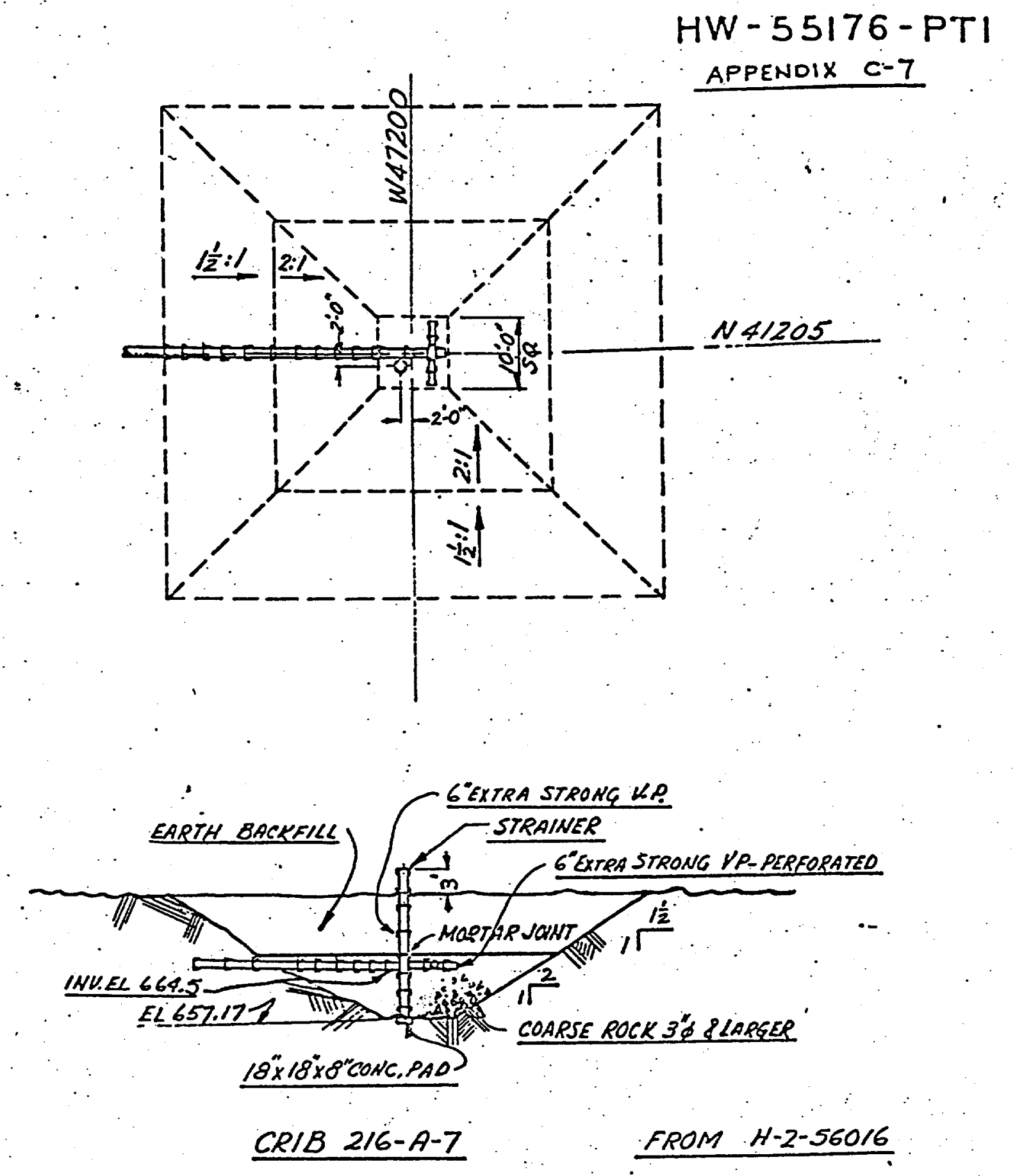

A. 3 


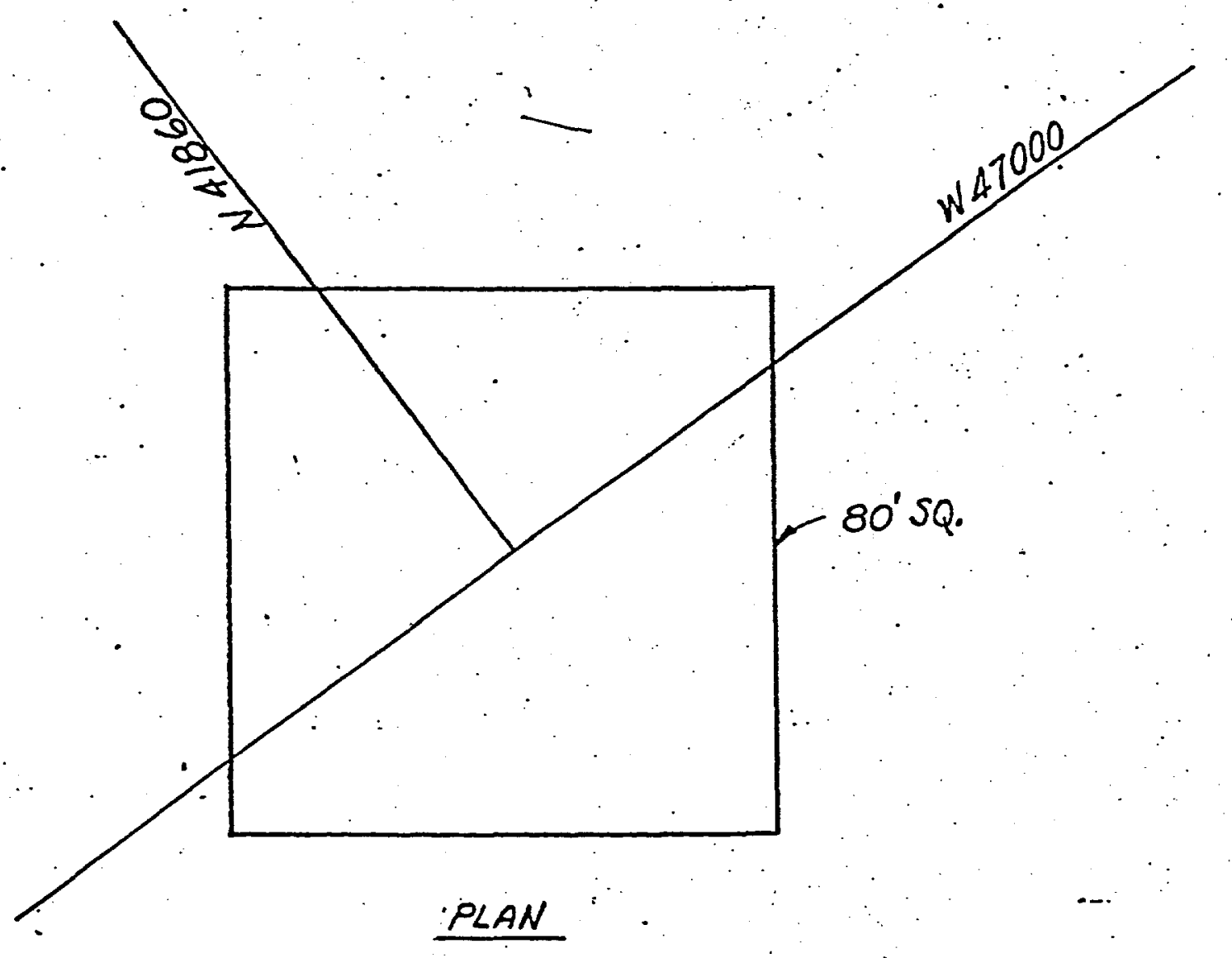

EXCAVATION FILLED - CRIB NEVER BUILT

START. UP WASTES DISPOSED IN EXCAVATION

$216-A-18$

TAKEN FROM H-2.55900

A. 4 


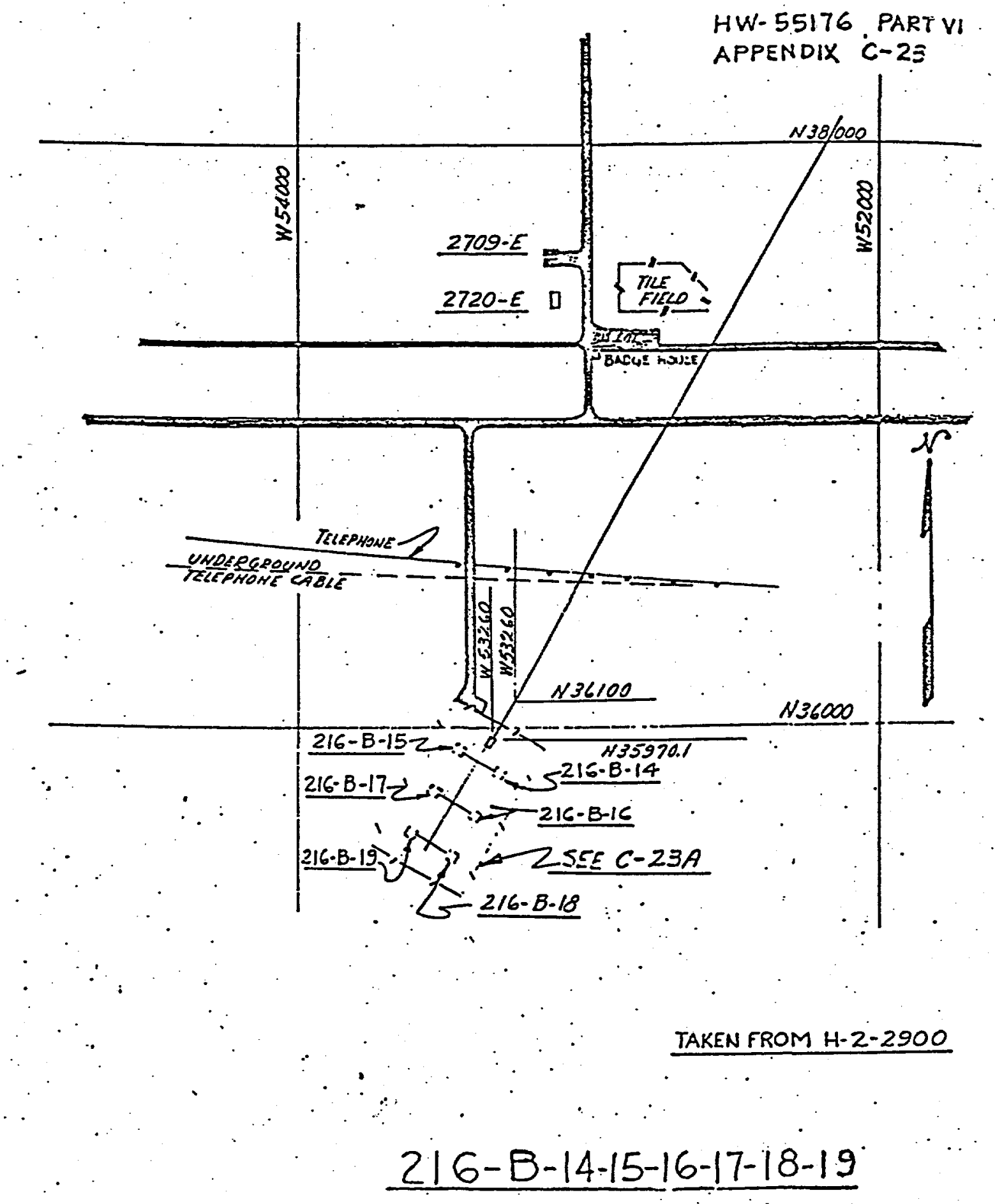

A. 5 


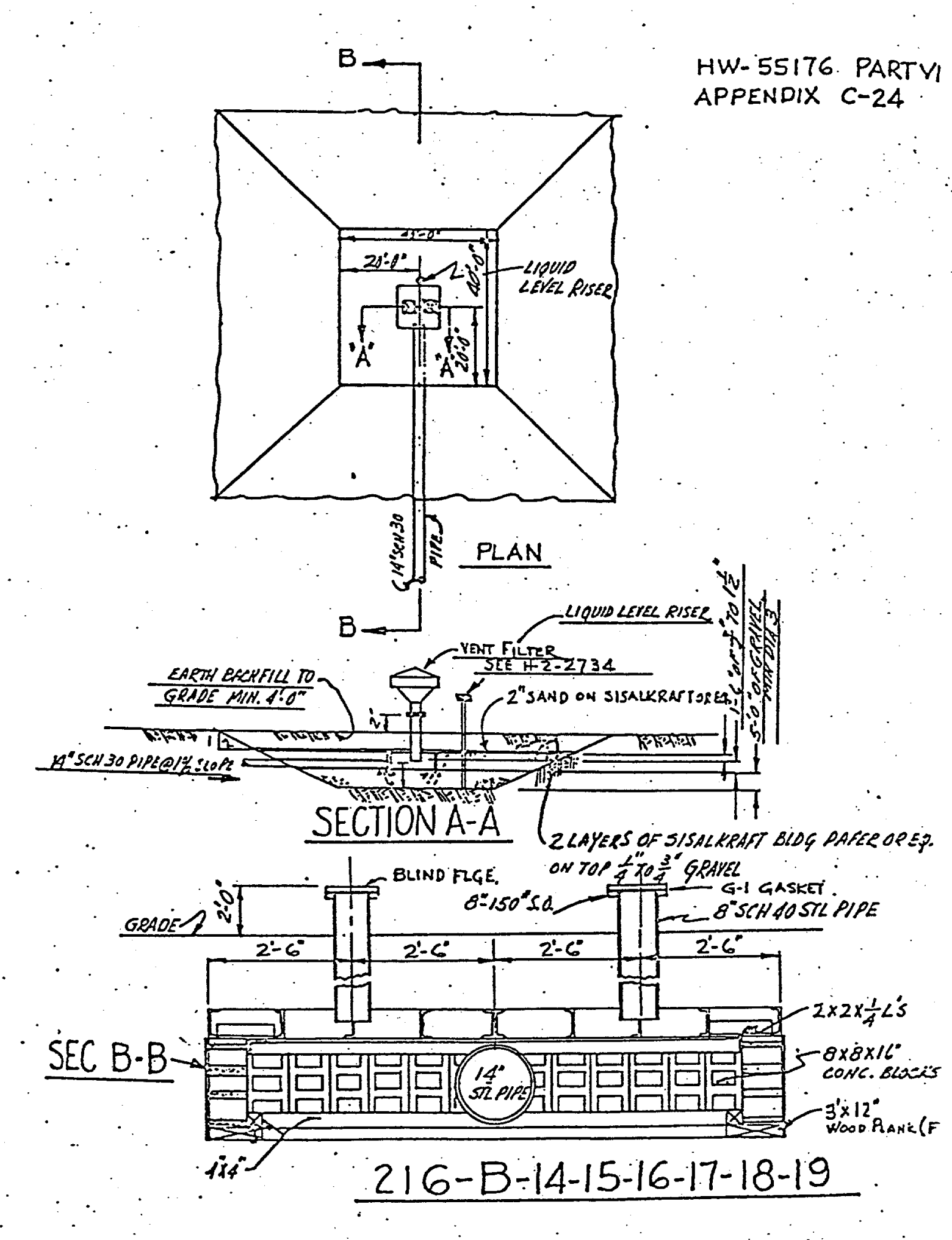


HIV 1

AFY'NDIX C-2E

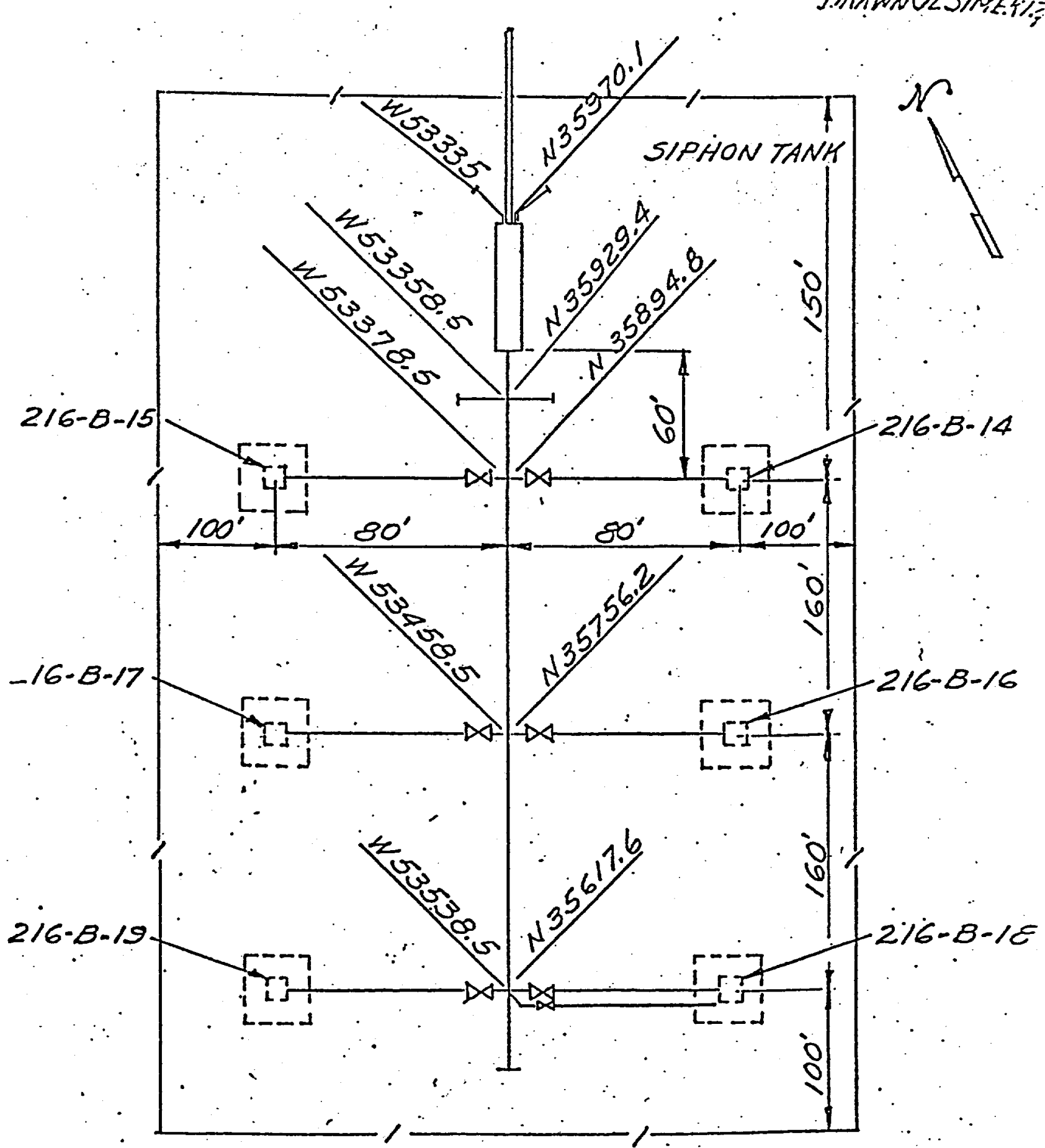

$\therefore \quad 216-8-14-15-16-17-18-19$

A. 7 
H1W55176.PPAS

APPEAIJIX C C. 25

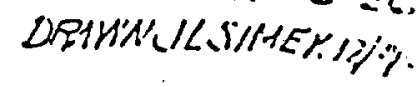

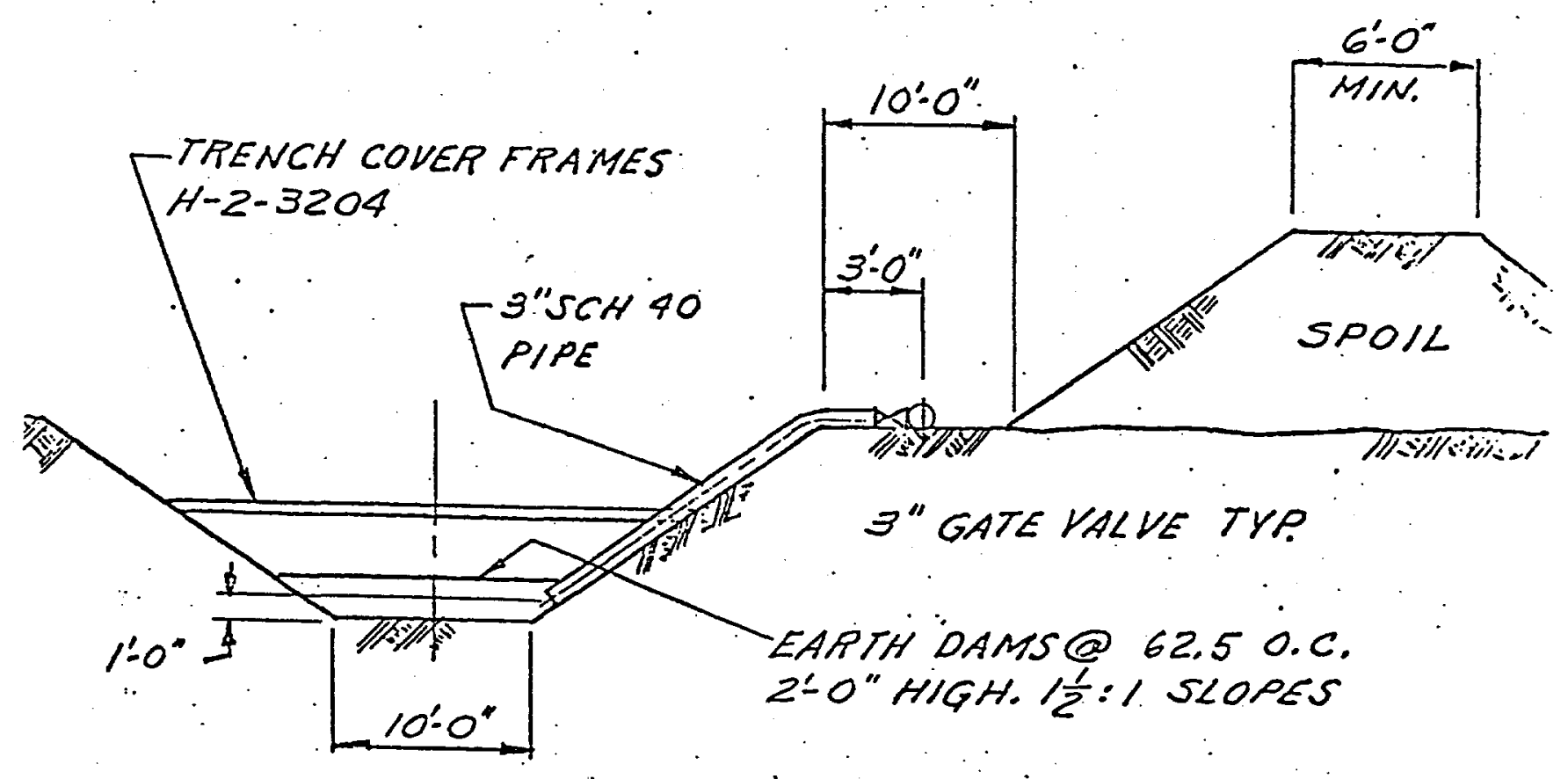

TYPICAL SECTION.

$\frac{216-8-20-21-22-23-24-25-26 \cdot 27 \cdot 28-52}{A .8}$ 


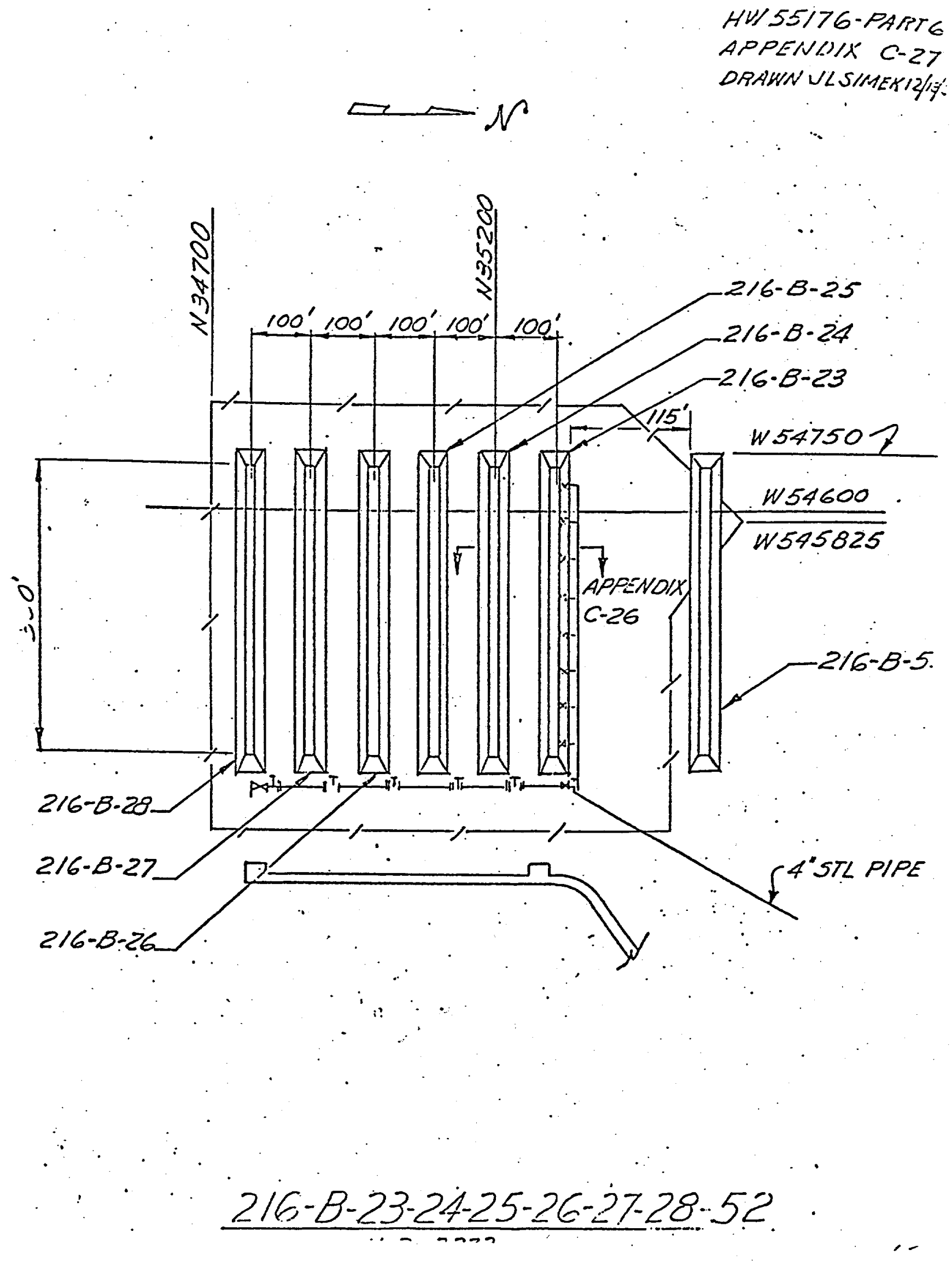


HUT 55/76-PAP. APPENDIX C.a. DPAWN ILSIMESTOYOY.
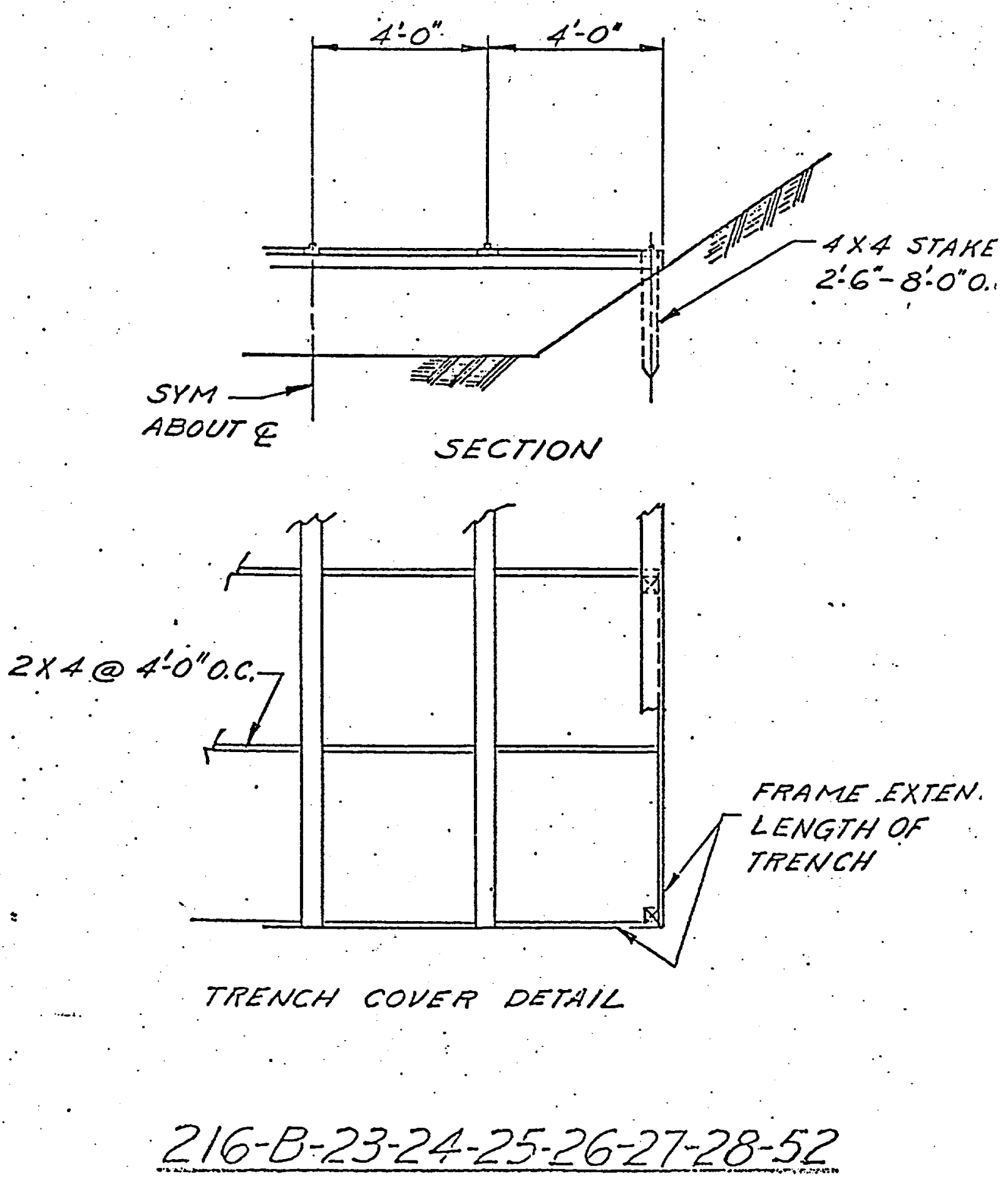

A. 10 
HW-55/76-PAPT APPENOIX C.23 DPAWN U... SIMEN WIS:

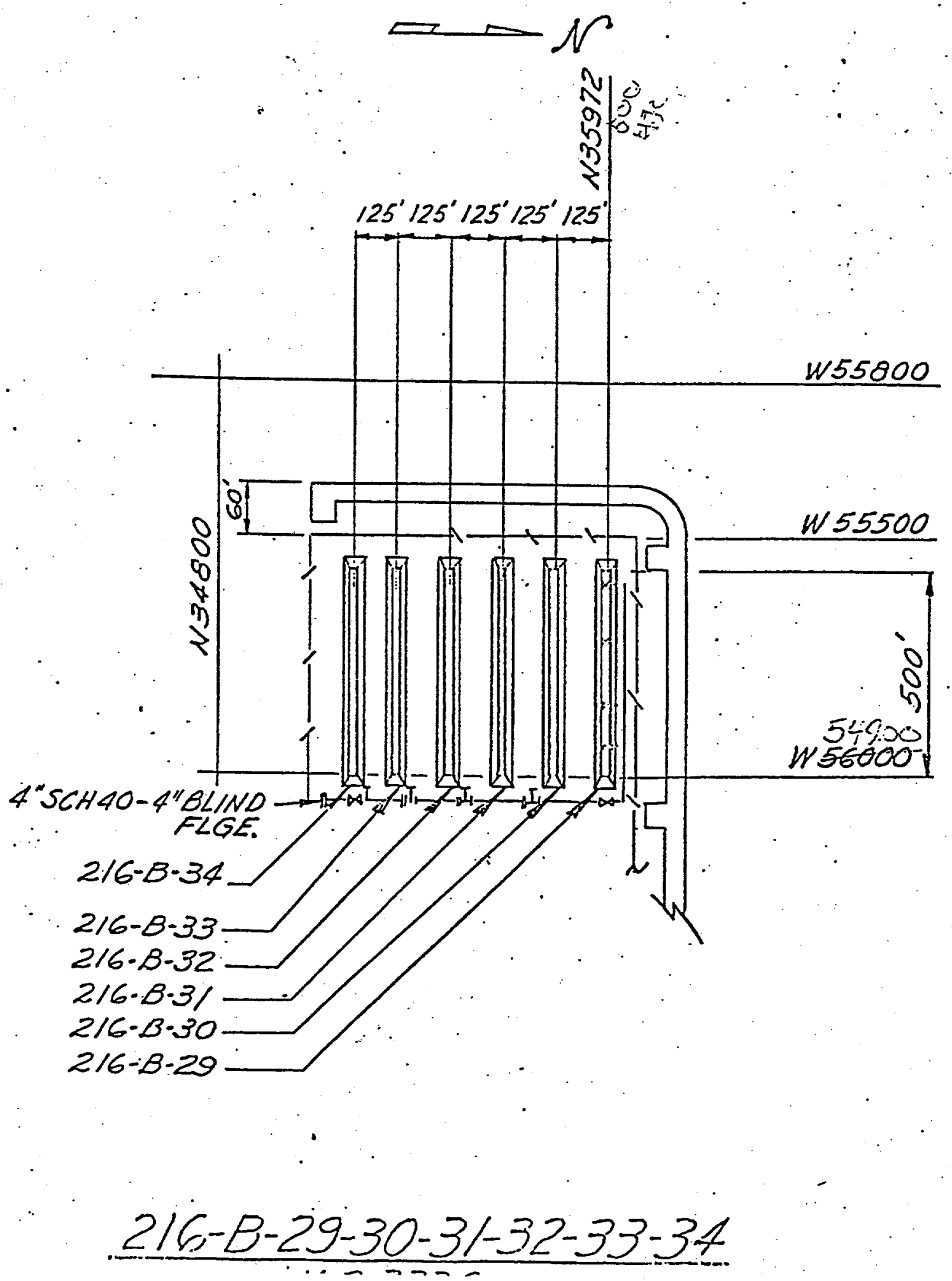

A.11 
HW- 55176 PARTVI APPENDIX C-30

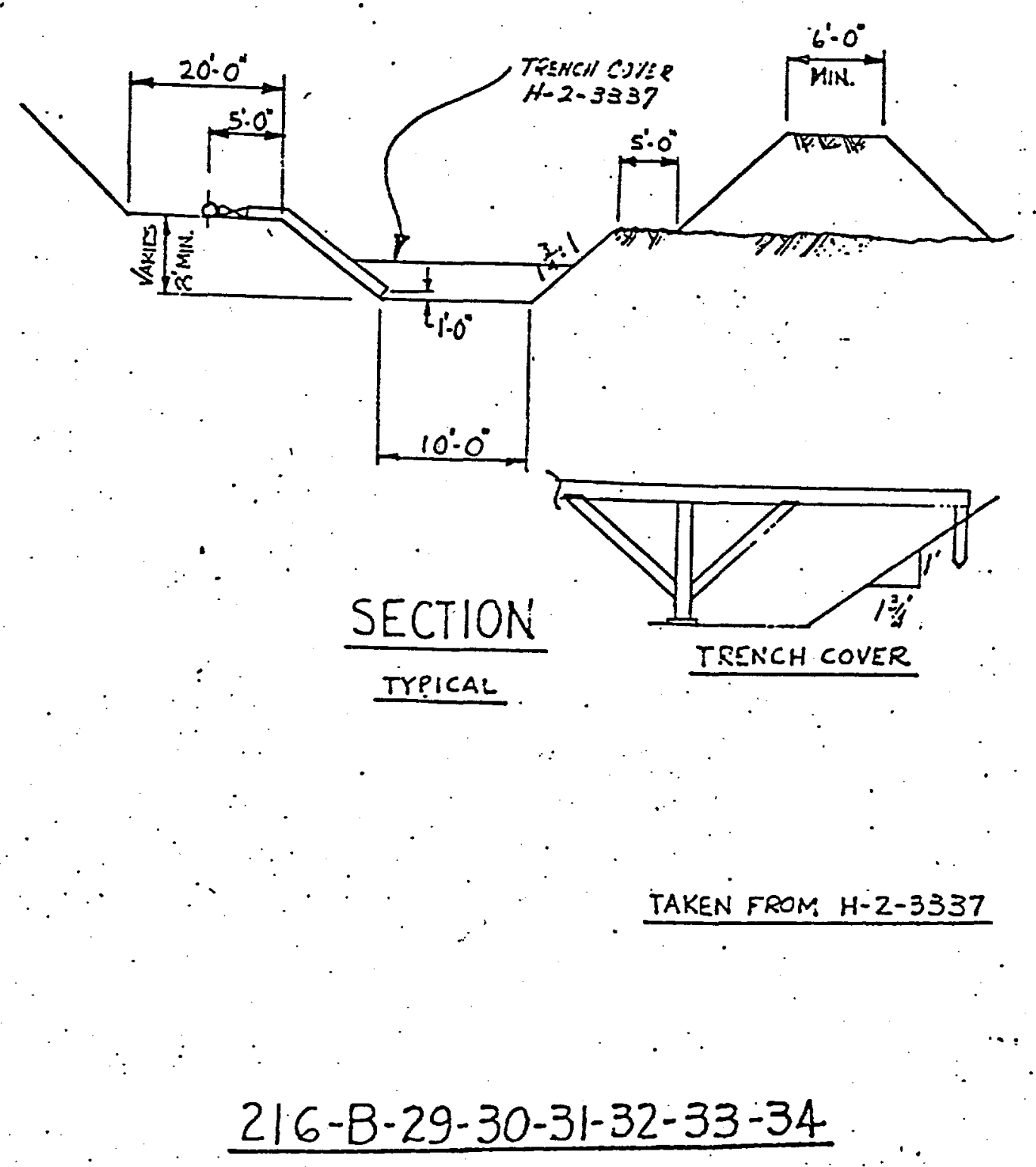

A. 12 


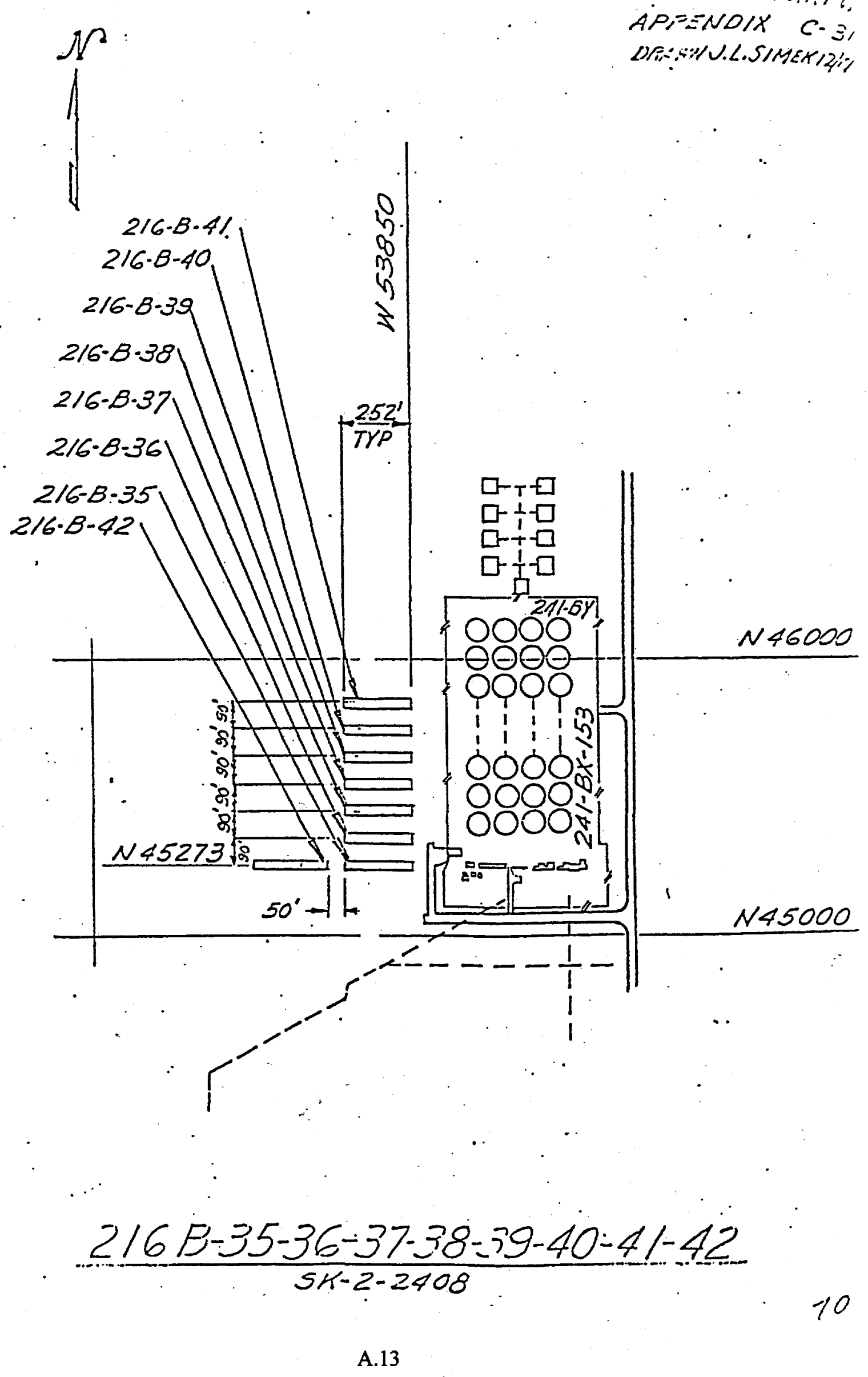


APPENDIX C-Z?

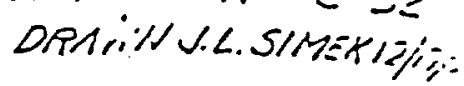

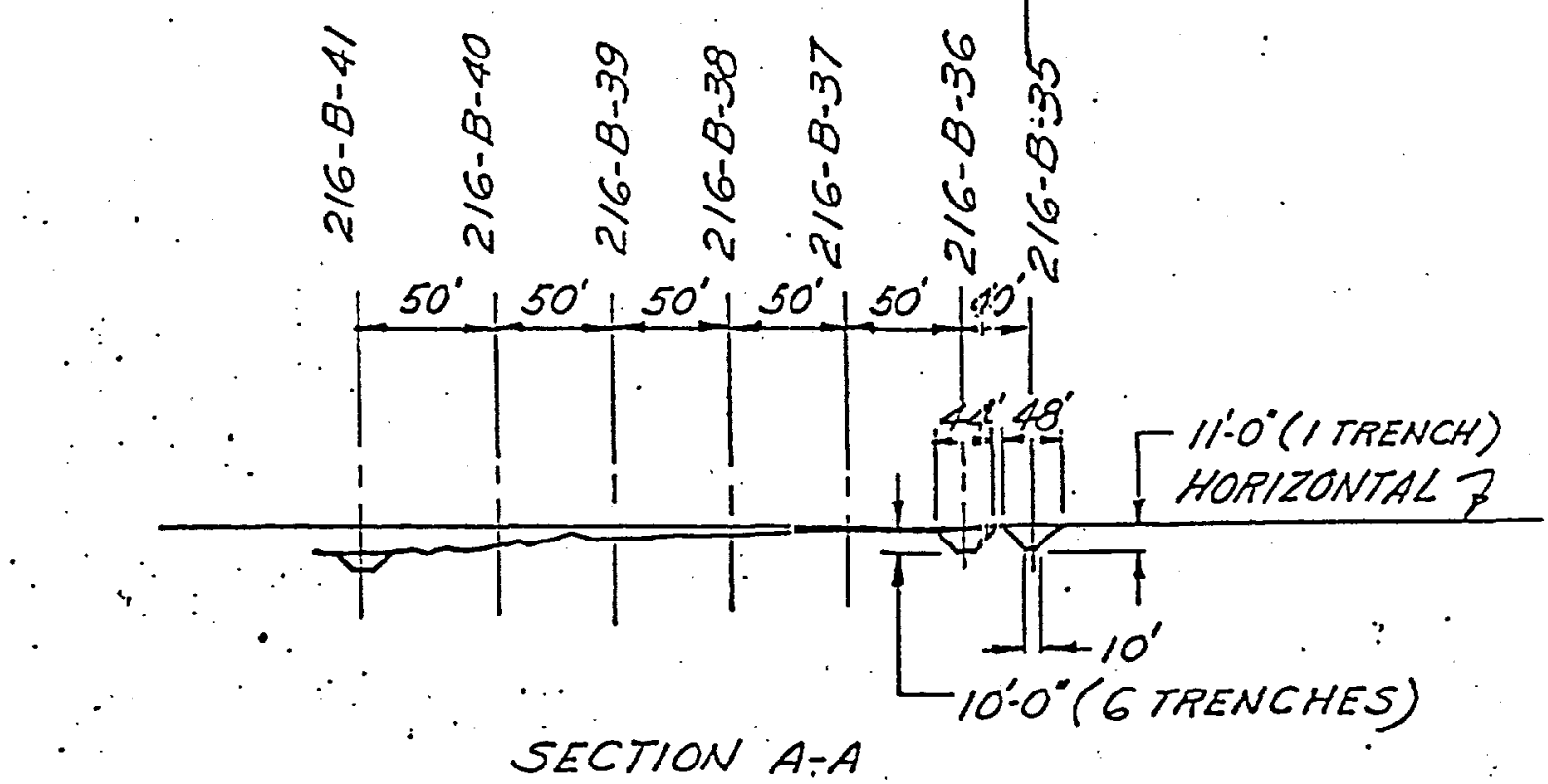

SECTION A-A

$$
\frac{216 B-35-36-37-38-39-40-41-42}{5 *-2-2408}
$$

A.14

$-11$ 


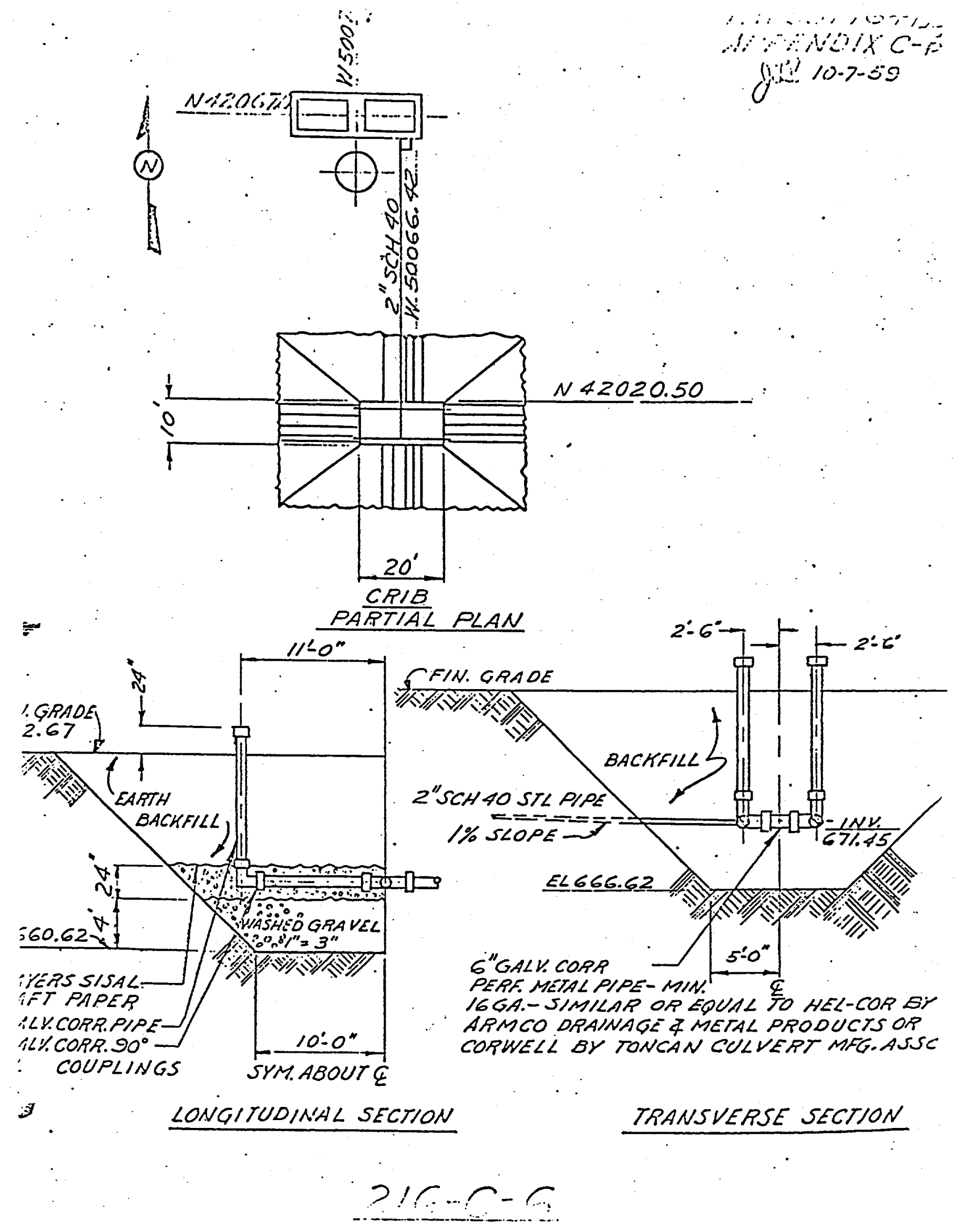

A. 15 
8
$80-8=9$

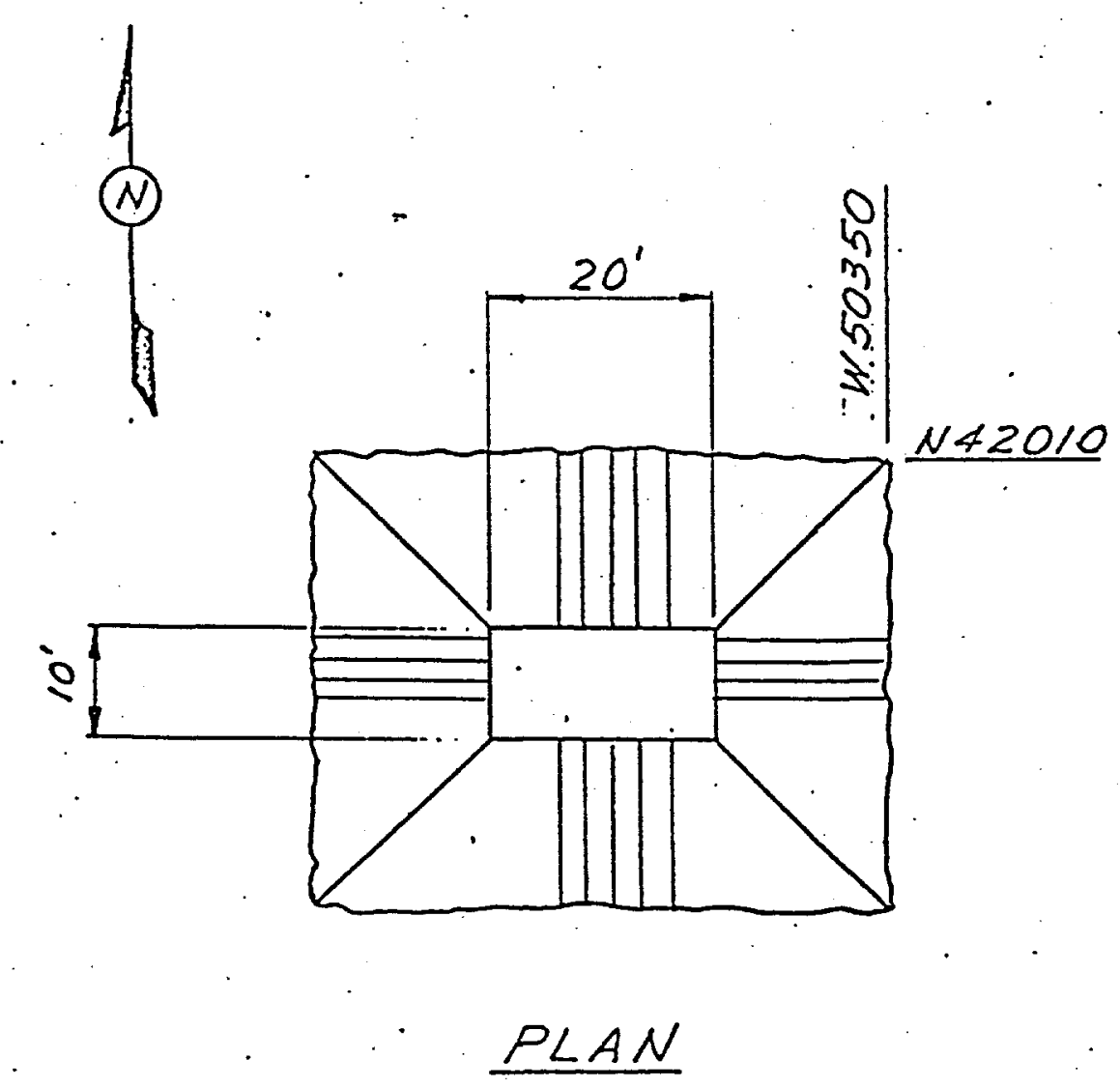

FOR LONGITUDINAL \& TRANSVEPSE SECTION-SEE 216-C- 6 CRIB

$216-C-5$

A.16 
Appendix B

Contaminant Inventories for Facilities Scheduled to be Monitored in Fiscal Year 1999. All data are from Maxfield (1979) and DOE (1993a, 1993b, and 1993c) 
Table B.1. Inventories of Contaminants Disposed the 216-A-2 Crib, the 216-A-4 Crib, 216-A-7, and the 216-A-18 Trench

\begin{tabular}{|c|c|c|c|c|}
\hline $\begin{array}{c}\text { Radionuclide or } \\
\text { Chemical }\end{array}$ & $\begin{array}{c}\text { 216-A-2 } \\
\text { Quantity }^{(\mathrm{a})}\end{array}$ & $\begin{array}{l}216-A-4 \\
\text { Quantity }\end{array}$ & $\begin{array}{l}217-A-7 \\
\text { Quantity }\end{array}$ & $\begin{array}{c}216-A-18 \\
\text { Quantity }\end{array}$ \\
\hline${ }^{60} \mathrm{Co}$ & 0.0297 & 0.0226 & 0.00204 & 0.00179 \\
\hline${ }^{90} \mathrm{Sr}$ & 0.921 & 4.39 & 0.431 & 0.042 \\
\hline${ }^{137} \mathrm{Cs}$ & 1.45 & 6.93 & 2.31 & 0.0444 \\
\hline $\mathrm{Pu}$ (total) (g) & 130 & 140 & 1 & 0.1 \\
\hline${ }^{239} \mathrm{Pu}$ & 7.42 & 7.99 & 0.0571 & 0.00571 \\
\hline${ }^{240} \mathrm{Pu}$ & 2 & 2.16 & 0.0154 & 0.00154 \\
\hline${ }^{99} \mathrm{Tc}$ & 0.00102 & 0.0000516 & 0.000004 & $3.38 \times 10^{-3}$ \\
\hline${ }^{106} \mathrm{Ru}$ & 0.0000000782 & 0.0000000438 & 0.00000011 & $2.75 \times 10^{-12}$ \\
\hline $\mathrm{U}$ (total) & 0.026 & 0.133 & 0.00227 & 0.469 \\
\hline${ }^{238} \mathrm{U}$ & 0.0262 & 0.134 & 0.00228 & 0.472 \\
\hline Alpha & 7.98 & 8.6 & 0.0614 & 0.00614 \\
\hline Beta & 4.71 & 2.21 & 5.29 & 0.172 \\
\hline TBP & 70,000 & & 100,000 & \\
\hline NPH & 120,000 & & 180,000 & \\
\hline Sodium & 4,000 & & & \\
\hline Sulfate & 5,000 & & & \\
\hline Sodium dichromate & 110 & & & \\
\hline Nitrate & 300 & & & 730 \\
\hline \multicolumn{5}{|c|}{$\begin{array}{l}\text { (a) Radionuclides are reported in Ci unless noted otherwise. All radionuclides are decay } \\
\text { corrected to December } 31,1989 \text { except }{ }^{238} \mathrm{U} \text { which is corrected to April } 1,1986 \text { and }{ }^{99} \mathrm{Tc} \\
\text { which is corrected to December } 31,1996 \text {. (Also, for } 216-\mathrm{A}-18 \text { only, Pu and beta are decay } \\
\text { corrected to April 1, 1986.) Chemical quantities are reported in kilograms unless noted } \\
\text { otherwise. All data is from DOE/RL-92-04 (1993) except }{ }^{99} \mathrm{Tc} \text { which is from Diediker } \\
\text { (1998). }\end{array}$} \\
\hline
\end{tabular}


Table B.2. Contaminant Inventories for the Cribs in the BC Controlled Area

\begin{tabular}{|c|c|c|c|c|c|c|}
\hline $\begin{array}{l}\text { Radionuclide } \\
\text { or Chemical }\end{array}$ & $\begin{array}{l}\text { 216-B-14 } \\
\text { Quantity }^{(2)}\end{array}$ & $\begin{array}{l}216-\bar{B}-15 \\
\text { Quantity }\end{array}$ & $\begin{array}{l}216-B-16 \\
\text { Quantity }\end{array}$ & $\begin{array}{l}216 \mathrm{~B}-17 \\
\text { Quantity }\end{array}$ & $\begin{array}{l}216-B-18 \\
\text { Quantity }\end{array}$ & $\begin{array}{l}216-B-19 \\
\text { Quantity }\end{array}$ \\
\hline${ }^{106} \mathrm{Ru}$ & 0.0152 & 0.00678 & 0.00334 & 0.0000642 & 0.00488 & 0.0152 \\
\hline${ }^{90} \mathrm{Sr}$ & 172 & 87.3 & 302 & 68.9 & 81.8 & 88.3 \\
\hline${ }^{137} \mathrm{Cs}$ & 114 & 92.4 & 296 & 100 & 114 & 126 \\
\hline${ }^{60} \mathrm{Co}$ & 0.103 & 0.109 & 0.103 & 0.0204 & 0.103 & 0.117 \\
\hline $\mathrm{U}$ (total) & 0.0726 & 0.0348 & 0.107 & 0.118 & 0.0786 & 0.0605 \\
\hline${ }^{238} \mathrm{U}$ & 0.073 & 0.0348 & 0.108 & 0.119 & 0.0791 & 0.0606 \\
\hline $\mathrm{Pu}$ (total) (g) & 25 & 5 & 10 & 10 & 10 & 10 \\
\hline${ }^{239} \mathrm{Pu}$ & 1.43 & 0.285 & 0.571 & 0.571 & 0.571 & 0.571 \\
\hline${ }^{240} \mathrm{Pu}$ & 0.385 & 0.077 & 0.154 & 0.154 & 0.154 & 0.154 \\
\hline${ }^{99} \mathrm{Tc}$ & 0.0753 & 0.088 & 0.0921 & 0.00275 & 0.0441 & 0.000133 \\
\hline${ }^{3} \mathrm{H}$ & & & 450 & & & \\
\hline Alpha & 1.53 & 0.307 & 0.614 & 0.614 & 0.614 & 0.614 \\
\hline Beta & 567 & 35.7 & 1180 & 330 & 385 & 418 \\
\hline Ferrocyanide & 5,000 & 3,300 & 3,000 & 1,800 & 5,000 & 3,400 \\
\hline Nitrate & $1,500,000$ & 900,000 & $1,100,000$ & $1,100,000$ & $1,000,000$ & $1,500,000$ \\
\hline Sulfate & 50,000 & 60,000 & 110,000 & 90,000 & 70,000 & 90,000 \\
\hline Sodium & 600,000 & 40,000 & 500,000 & 500,000 & 400,000 & 700,000 \\
\hline Phosphate & 40,000 & 50,000 & 70,000 & 60,000 & 50,000 & 100,000 \\
\hline Volume (L) & $8,710,000$ & $6,320,000$ & $5,600,000$ & $3,410,000$ & $8,520,000$ & $6,400,000$ \\
\hline \multicolumn{7}{|c|}{$\begin{array}{l}\text { (a) Radionuclides are reported in curies unless noted otherwise. All radionuclides are decay corrected } \\
\text { to December } 31,1989 \text { except }{ }^{3} \mathrm{H},{ }^{238} \mathrm{U},{ }^{60} \mathrm{Co},{ }^{239} \mathrm{Pu} \text {, and }{ }^{240} \mathrm{Pu} \text { which are decayed to April } 1,1986 \text {, } \\
{ }^{99} \mathrm{Tc} \text { which is decayed to December } 31,1996 \text {, and }{ }^{106} \mathrm{Ru} \text { which is decayed to June } 30,1978 . \\
\text { Chemical quantities are reported in kilograms unless otherwise stated. All data is from DOE } \\
\text { (1993b) except }{ }^{99} \mathrm{Tc} \text { which is from Diediker }(1998) \text { and }{ }^{106} \mathrm{Ru} \text { which is from Maxfield (1979). }\end{array}$} \\
\hline
\end{tabular}


Table B.3. Contaminant Inventories for Specific Retention Trenches in the BC Controlled Area

\begin{tabular}{|c|c|c|c|c|c|c|}
\hline $\begin{array}{l}\text { Radionuclide } \\
\text { or Chemical }\end{array}$ & $\begin{array}{l}216-\mathrm{B}-23 \\
\text { Quantity }\end{array}$ & $\begin{array}{l}\text { 216-B-25 } \\
\text { Quantity }\end{array}$ & $\begin{array}{l}\text { 216-B-26 } \\
\text { Quantity }\end{array}$ & $\begin{array}{l}\text { 216-B-27 } \\
\text { Quantity }\end{array}$ & $\begin{array}{l}216-\mathrm{B}-30 \\
\text { Quantity }\end{array}$ & $\begin{array}{l}\text { 216-B-31 } \\
\text { Quantity }\end{array}$ \\
\hline${ }^{90} \mathrm{Sr}$ & 62.5 & 88.3 & 475 & 263 & 265 & \\
\hline${ }^{137} \mathrm{Cs}$ & 50.9 & 25.2 & 438 & 15.8 & 1570 & \\
\hline${ }^{60} \mathrm{Co}$ & 0.137 & 0.141 & 0.223 & 0.177 & 0.0397 & \\
\hline $\mathrm{U}$ (total) & 0.052 & 0.0051 & 0.196 & 0.114 & 0.0293 & \\
\hline${ }^{238} \mathrm{U}$ & 0.0523 & 0.513 & 0.197 & 0.115 & 0.0295 & \\
\hline $\mathrm{Pu}$ (total) (g) & 1.8 & 2.0 & 2.5 & $0.7^{(\mathrm{b})}$ & 2.1 & \\
\hline${ }^{239} \mathrm{Pu}$ & 0.102 & 0.114 & 0.143 & 0.04 & 0.12 & \\
\hline${ }^{240} \mathrm{Pu}$ & 0.0277 & 0.301 & 0.385 & 0.0108 & 0.0323 & \\
\hline${ }^{99} \mathrm{Tc}$ & 0.0612 & 0.0637 & 0.0878 & 0.0688 & 0.00186 & 0.0239 \\
\hline Alpha & 0.111 & 0.123 & 0.0153 & 0.043 & 0.129 & \\
\hline Beta & 226 & 229 & 1800 & 560 & 3,540 & \\
\hline $\mathrm{FeCN}$ & 2,400 & 2,000 & 3,100 & 2,300 & 2,500 & 2,500 \\
\hline Nitrate & $1,000,000$ & 500,000 & 800,000 & 600,000 & $1,100,000$ & $1,100,000$ \\
\hline Sulfate & 60,000 & 40,000 & 60,000 & 50,000 & 110,000 & 90,000 \\
\hline Sodium & 400,000 & 220,000 & 350,000 & 260,000 & 500,000 & 500,000 \\
\hline Phosphate & 60,000 & 27,000 & 40,000 & 32,000 & 70,000 & 60,000 \\
\hline Volume (L) & $4,520,000$ & $3,760,000$ & $5,880,000$ & $4,420,000$ & $4,780,000$ & $4,740,000$ \\
\hline \multicolumn{7}{|c|}{$\begin{array}{l}\text { (a) Radionuclides are reported in Ci unless noted otherwise. All radionuclides are decay corrected to } \\
\text { December } 31,1989 \text { except }{ }^{60} \mathrm{Co},{ }^{239} \mathrm{Pu},{ }^{240} \mathrm{Pu} \text { and }{ }^{238} \mathrm{U} \text { which are decayed to April } 1,1986 \text { and }{ }^{99} \mathrm{Tc} \\
\text { which is decayed to December } 31,1996 \text {. Chemical quantities are reported in kilograms unless } \\
\text { noted otherwise. All data is from DOE (1993b) except }{ }^{99} \mathrm{Tc} \text { which is from Diediker (1998). } \\
\text { (b) Total Pu from Maxfield (1979). }\end{array}$} \\
\hline
\end{tabular}


Table B.4. Contaminant Inventories for the Specific Retention Trenches West of the 241-BX Tank Farm

\begin{tabular}{|c|c|c|c|c|c|c|}
\hline $\begin{array}{l}\text { Radionuclide or } \\
\text { Chemical }\end{array}$ & $\begin{array}{l}\text { 216-B-35 } \\
\text { Quantity (a) }\end{array}$ & $\begin{array}{l}216-B-36 \\
\text { Quantity }\end{array}$ & $\begin{array}{l}216-B-37 \\
\text { Quantity }\end{array}$ & $\begin{array}{l}216-B-38 \\
\text { Quantity }\end{array}$ & $\begin{array}{l}\text { 216-B-41 } \\
\text { Quantity }\end{array}$ & $\begin{array}{l}216-B-42 \\
\text { Quantity }\end{array}$ \\
\hline${ }^{106} \mathrm{Ru}$ & 0.0000148 & 0.0000305 & 0.0000323 & 0.0000362 & 0.00000847 & 0.000193 \\
\hline${ }^{90} \mathrm{Sr}$ & 96.4 & 199 & 6.56 & 759 & 19.3 & 463 \\
\hline${ }^{137} \mathrm{Cs}$ & 185 & 336 & 1,350 & 221 & 386 & 42.7 \\
\hline${ }^{60} \mathrm{Co}$ & 0.00047 & 0.0011 & 0.0157 & 0.00094 & 0.000160 & 0.179 \\
\hline $\mathrm{U}$ (total) & 0.00557 & 0.00532 & 0.00121 & 0.0141 & 0.00250 & 0.227 \\
\hline${ }^{238} \mathrm{U}$ & 0.00559 & 0.00532 & 0.00121 & 0.0142 & 0.00251 & 0.228 \\
\hline $\mathrm{Pu}($ total) (g) & 1.2 & 0.8 & 2 & 1.2 & 0.3 & 10 \\
\hline${ }^{239} \mathrm{Pu}$ & 0.0685 & 0.0457 & 0.114 & 0.0685 & 0.0171 & 0.0571 \\
\hline${ }^{240} \mathrm{Pu}$ & 0.0185 & 0.0123 & 0.0308 & 0.0185 & 0.00462 & 0.154 \\
\hline${ }^{99} \mathrm{Tc}$ & 0.000135 & 0.000378 & 0.000202 & 0.0000896 & 0.000146 & 0.00133 \\
\hline Alpha & 0.0737 & 0.0491 & 0.123 & 0.0737 & 0.0184 & 0.614 \\
\hline Beta & 549 & 1,040 & 2,600 & 1,940 & 780 & 1,010 \\
\hline Fluoride & 2,600 & 5,000 & 50,000 & 4,000 & 4,000 & \\
\hline Sodium Aluminate & 10,000 & 24,000 & 250,000 & 18,000 & 18,000 & \\
\hline Nitrate & 90,000 & 160,000 & $1,700,000$ & 120,000 & 120,000 & 210,000 \\
\hline Sulfate & 4,000 & 8,000 & 90,000 & 6,000 & 6,000 & 150,000 \\
\hline Sodium & 60,000 & 120,000 & $1,300,000$ & 90,000 & 90,000 & 90,000 \\
\hline Nitrite & 10,000 & 18,000 & 200,000 & 13,000 & 13,000 & \\
\hline Phosphate & 20,000 & 40,000 & 400,000 & 27,000 & 27,000 & 11,000 \\
\hline Ferrocyanide & & & & & & 800 \\
\hline Volume (L) & $1,060,000$ & $1,940,000$ & $4,320,000$ & $1,640,000$ & $1,440,000$ & $1,500,000$ \\
\hline
\end{tabular}

(a) Radionuclides are reported in $\mathrm{Ci}$ unless noted otherwise. All radionuclides are decay corrected to December 31,1989 except ${ }^{60} \mathrm{Co},{ }^{239} \mathrm{Pu},{ }^{240} \mathrm{Pu}$ and ${ }^{238} \mathrm{U}$ which are decayed to April $1,1986,{ }^{99} \mathrm{Tc}$ which is decayed to December 31,1996 , and ${ }^{106} \mathrm{Ru}$ which is decayed to June 30,1978 . Chemical quantities are reported in kilograms unless noted otherwise. All data is from DOE (1993b) except ${ }^{99} \mathrm{Tc}$ which is from Diediker (1998) and ${ }^{106} \mathrm{Ru}$ which is from Maxfield (1979). 
Table B.5. Inventory of Contaminants Disposed to the $216-\mathrm{C}-5 \mathrm{Crib}$

\begin{tabular}{|c|c|c|c|c|c|}
\hline $\begin{array}{l}\text { Radionuclide } \\
\text { or Chemical }\end{array}$ & \multicolumn{2}{|c|}{ Quantity (a) } & \multicolumn{2}{|c|}{$\begin{array}{l}\text { Radionuclide or } \\
\text { Chemical }\end{array}$} & Quantity \\
\hline${ }^{106} \mathrm{Ru}$ & \multicolumn{2}{|c|}{0.000000000138} & \multicolumn{2}{|c|}{${ }^{60} \mathrm{Co}$} & 0.0018 \\
\hline${ }^{90} \mathrm{Sr}$ & \multicolumn{2}{|c|}{4.2 to 4.61} & \multicolumn{2}{|c|}{${ }^{238} \mathrm{U}$} & 0.0182 \\
\hline${ }^{137} \mathrm{Cs}$ & \multicolumn{2}{|c|}{0.0444 to 0.484} & \multicolumn{2}{|c|}{ Nitrate } & 8,000 \\
\hline $\mathrm{Pu}$ (total) (g) & \multicolumn{2}{|c|}{1.0} & \multicolumn{2}{|c|}{ Sodium } & 3,000 \\
\hline${ }^{99} \mathrm{Tc}$ & \multicolumn{2}{|c|}{0.000232} & & & \\
\hline $\begin{array}{l}\text { Radionuclide } \\
\text { or Chemical }\end{array}$ & $\begin{array}{l}\text { 216-B-32 } \\
\text { Quantity }\end{array}$ & $\begin{array}{l}\text { 216-B-33 } \\
\text { Quantity }\end{array}$ & $\begin{array}{l}216-\mathrm{B}-52 \\
\text { Quantity }\end{array}$ & $\begin{array}{l}216-\mathrm{B}-53 \mathrm{~A} \\
\text { Quantity }\end{array}$ & $\begin{array}{l}216-\mathrm{B}-58 \\
\text { Quantity }\end{array}$ \\
\hline${ }^{90} \mathrm{Sr}$ & 113 & 18.1 & 4.92 & 0.0538 & 5.55 \\
\hline${ }^{137} \mathrm{Cs}$ & 58.6 & 127 & 160 & 0.0559 & 4.4 \\
\hline${ }^{60} \mathrm{Co}$ & 0.0397 & 0.0327 & 0.113 & 0.0335 & 0.198 \\
\hline $\mathrm{U}$ (total) & 0.00367 & 0.00667 & 0.00998 & 0.00756 & 0.00304 \\
\hline${ }^{238} \mathrm{U}$ & 0.00368 & 0.0067 & 0.01 & 0.076 & 0.00305 \\
\hline $\mathrm{Pu}$ (total) (g) & 2.6 & 11.8 & 19 & 100 & 6.7 \\
\hline${ }^{239} \mathrm{Pu}$ & 0.148 & 0.674 & 1.08 & 5.71 & 0.393 \\
\hline${ }^{240} \mathrm{Pu}$ & 0.04 & 0.182 & 0.293 & 1.54 & 0.103 \\
\hline${ }^{99} \mathrm{Tc}$ & 0.0132 & 0.0114 & 0.000439 & 0.000142 & 0.0000573 \\
\hline Alpha & 0.16 & 0.724 & 1.17 & 6.14 & 0.411 \\
\hline Beta & 339 & 281 & 317 & 0.246 & 19.7 \\
\hline $\mathrm{FeCN}$ & 2,500 & 2,500 & 5,000 & & \\
\hline Nitrate & $1,000,000$ & $1,700,000$ & $2,100,000$ & 1 & 10 \\
\hline Sulfate & 90,000 & 90,000 & 80,000 & & \\
\hline Sodium & 500,000 & 700,000 & 860,000 & & \\
\hline Phosphate & 60,000 & 80,000 & 80,000 & & \\
\hline Volume (L) & $4,770,000$ & $4,740,000$ & $8,530,000$ & 549,000 & 999,0000 \\
\hline $\begin{array}{l}\text { (a) Radionucli } \\
\text { tables in D } \\
\text { representat } \\
\text { Chemical }\end{array}$ & are repor & $\begin{array}{l}\text { in } \mathrm{Ci} \text { unle } \\
{ }^{99} \mathrm{Tc} \text { wh }\end{array}$ & $\begin{array}{l}\text { noted othe } \\
h \text { is from I }\end{array}$ & $\begin{array}{l}\text { ise. All data } \\
\text { diker (1998) }\end{array}$ & $\begin{array}{l}\text { from } \\
\text { Data is } \\
1996 .\end{array}$ \\
\hline
\end{tabular}




\section{Appendix C}

Well Construction and Completion Summaries (as-built diagrams) for Boreholes and Wells Scheduled for Vadose Zone Monitoring in Fiscal Year 1999

(Well Construction and Completion Summaries are unavailable for boreholes 299-E13-52, -54 through -61 ; 299-E24-8, -53, -54; 299-E25-10, -54; and 299-E33-286 through -289) 


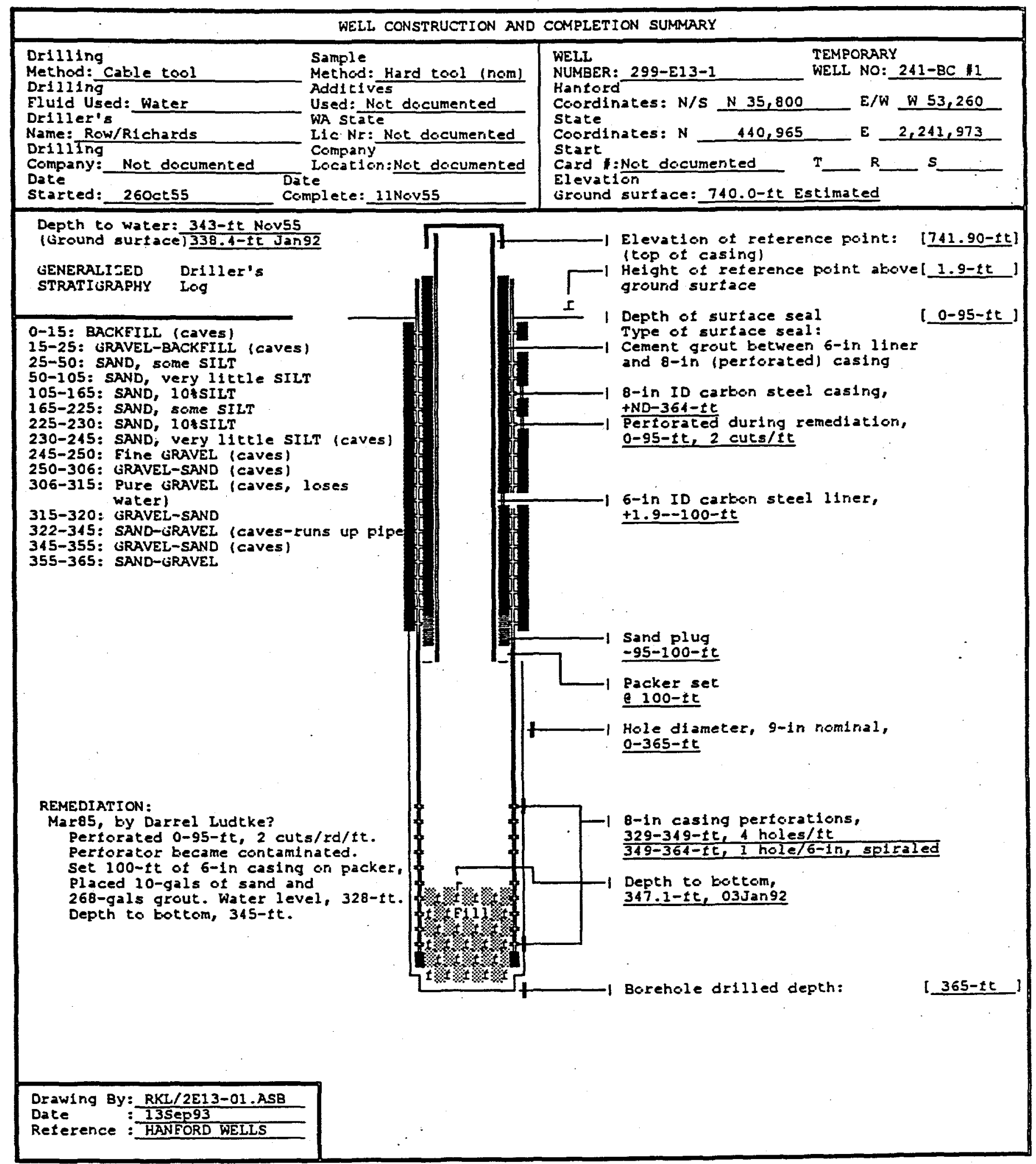

C. 1 


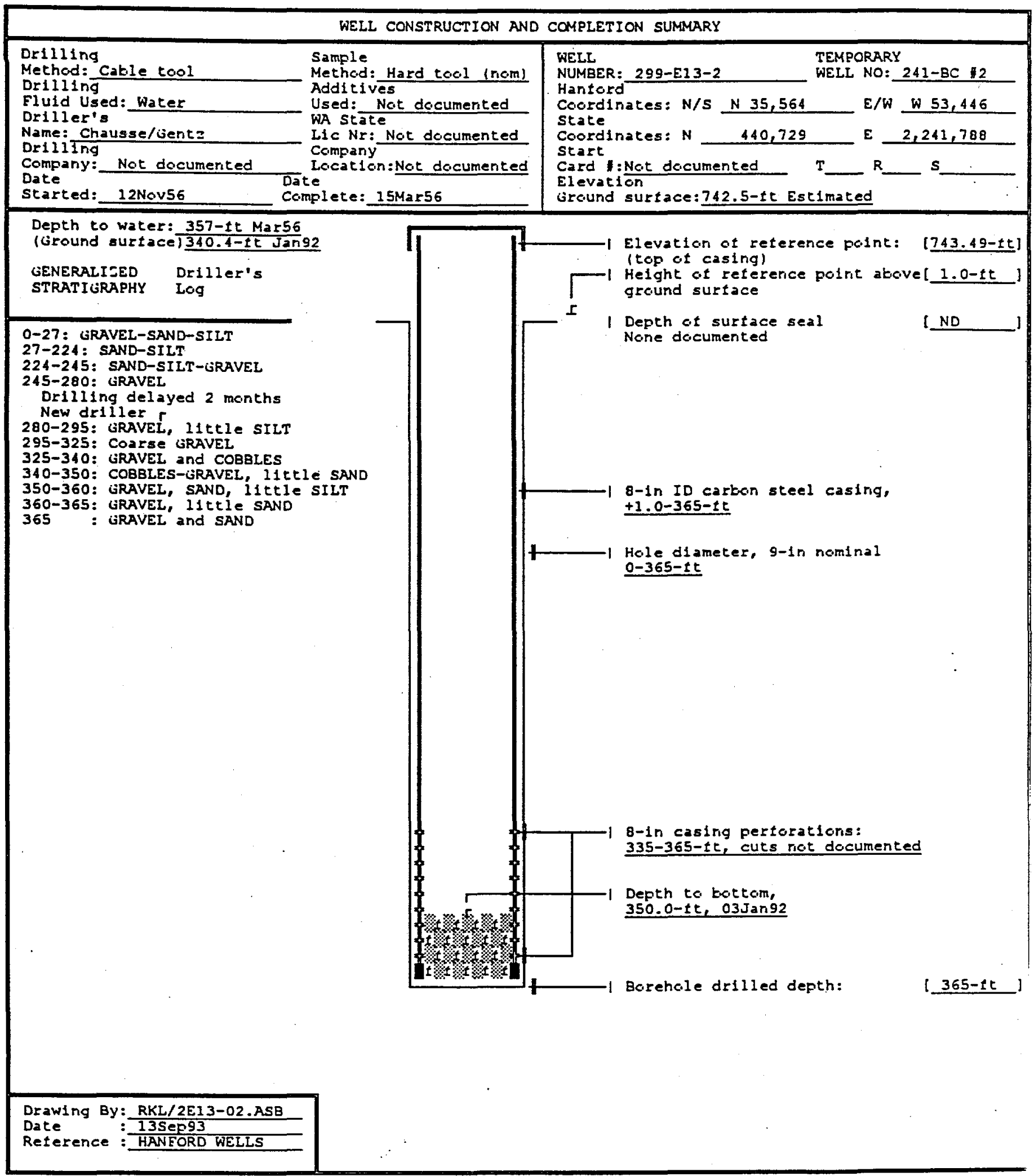




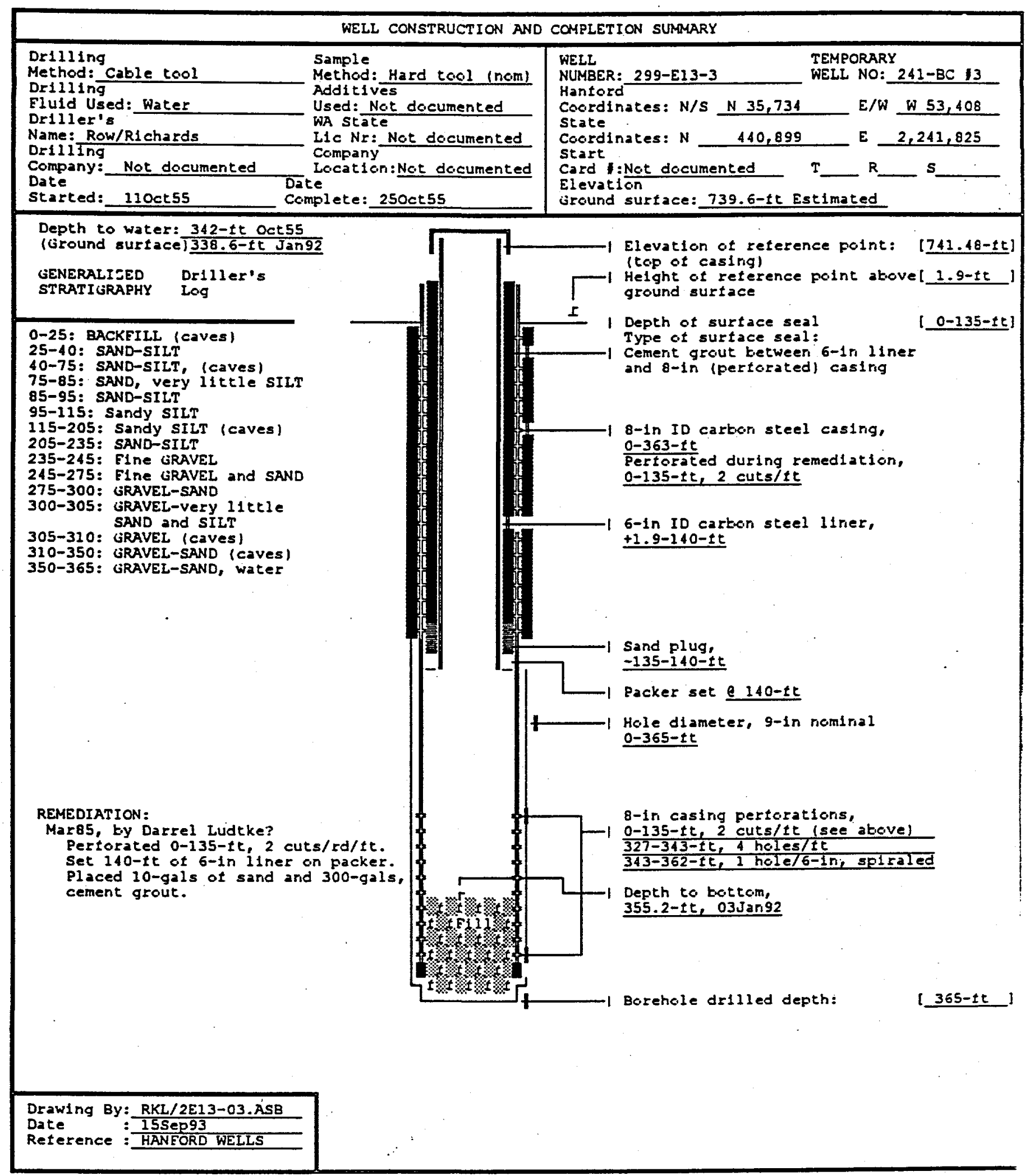


WELL CONSTRUCTION AND COMPLETION SUMMARY

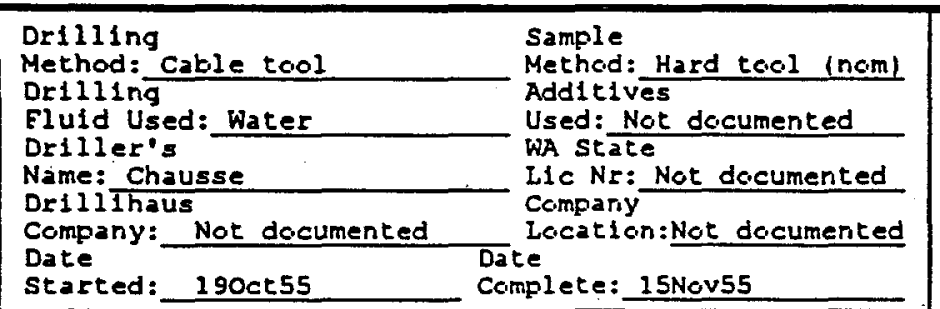

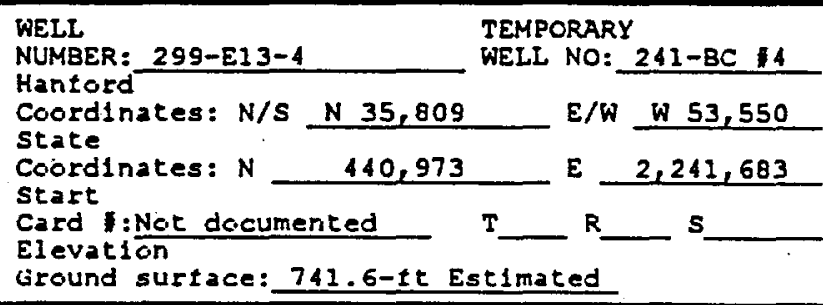

Depth to water: 362-tt Nav55

(Ground surtace $1339.5-t$ t Jan92

GENERALIEED DEIIler's

STRATIGRAPHY LOG

0-8: GRAVEL-SAND and SILT

8-19: SAND-SILT, GRAVEL

19-154: SAND-SILT

154-166: Pea GRAVEL, SAND-SILT

166-222: SAND-SILT

222-230: GRAVEL-SAND-SILT

230-235: SAND, SILT and GRAVEL

235-269: GRAVEL.

269-280: COBBLES-IRAVEI

280-290: GRAVEI

290-299: DYY GRAVEL (CAVES)

299-369: GRAVEI

REMEDIATION:

Mar85, by David Garcla?

Pertorated 0-95-tt, 2 cuts/rd/tt.

set 100-tt of 6-in casing on packer

Placed 10-gals of sand and

300-gals cement gout.

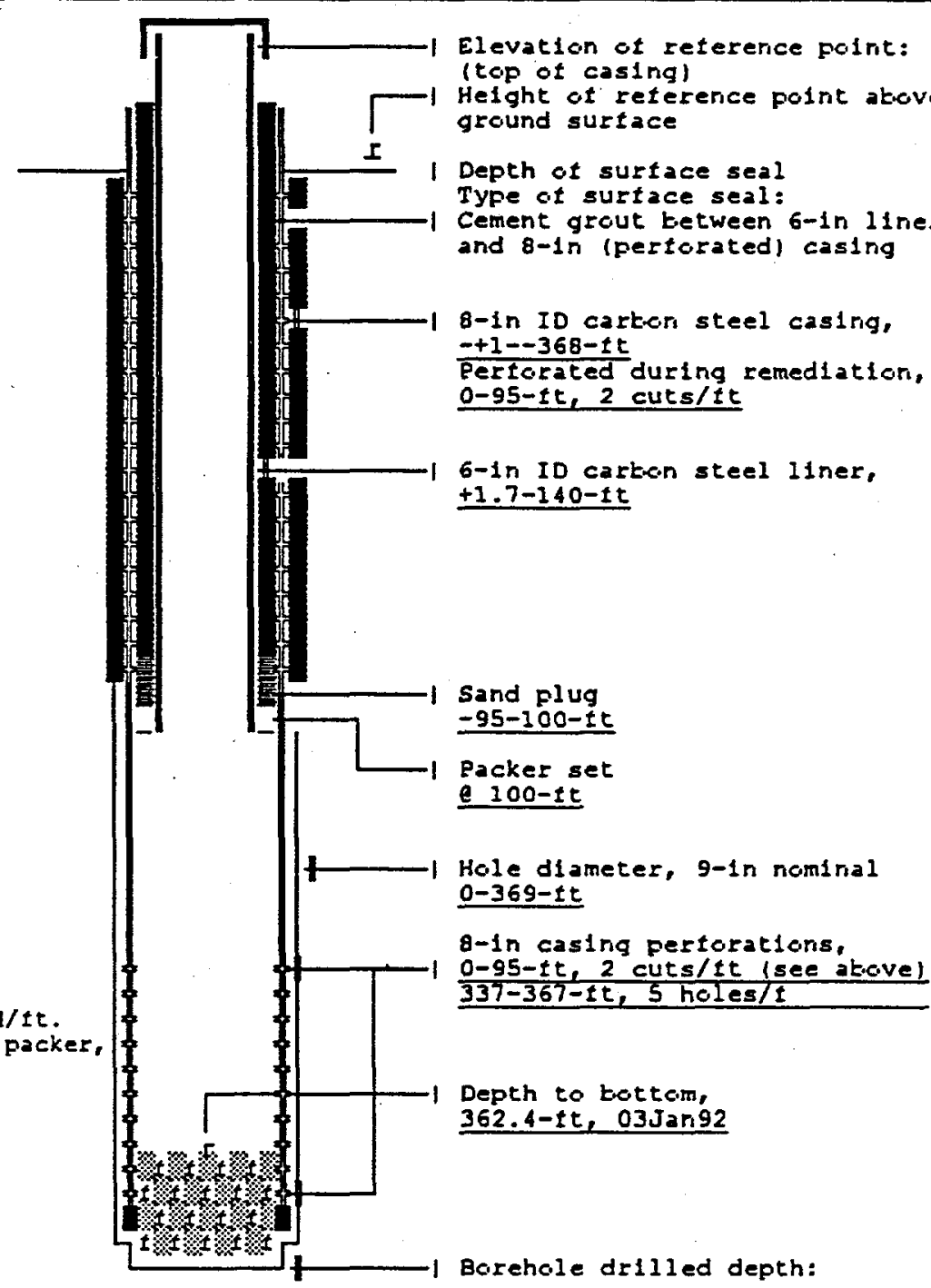

$[743.35-t t]$

el $1.7-t c$

$[0-95- \pm t]$ Type ot surtace seal:

Cement grout between 6-in IIner

and 8-1n (pertorated) casing

in castoring steel casing

$+1--368-t t$

Perforated during remediation.

$0-95- \pm t, 2$ cuts/tt

6-in ID carken steel Iner, $+1 \cdot 7-140-t t$

sand olug

Packer set

e $100-t t$

Barehale dr11led depth 


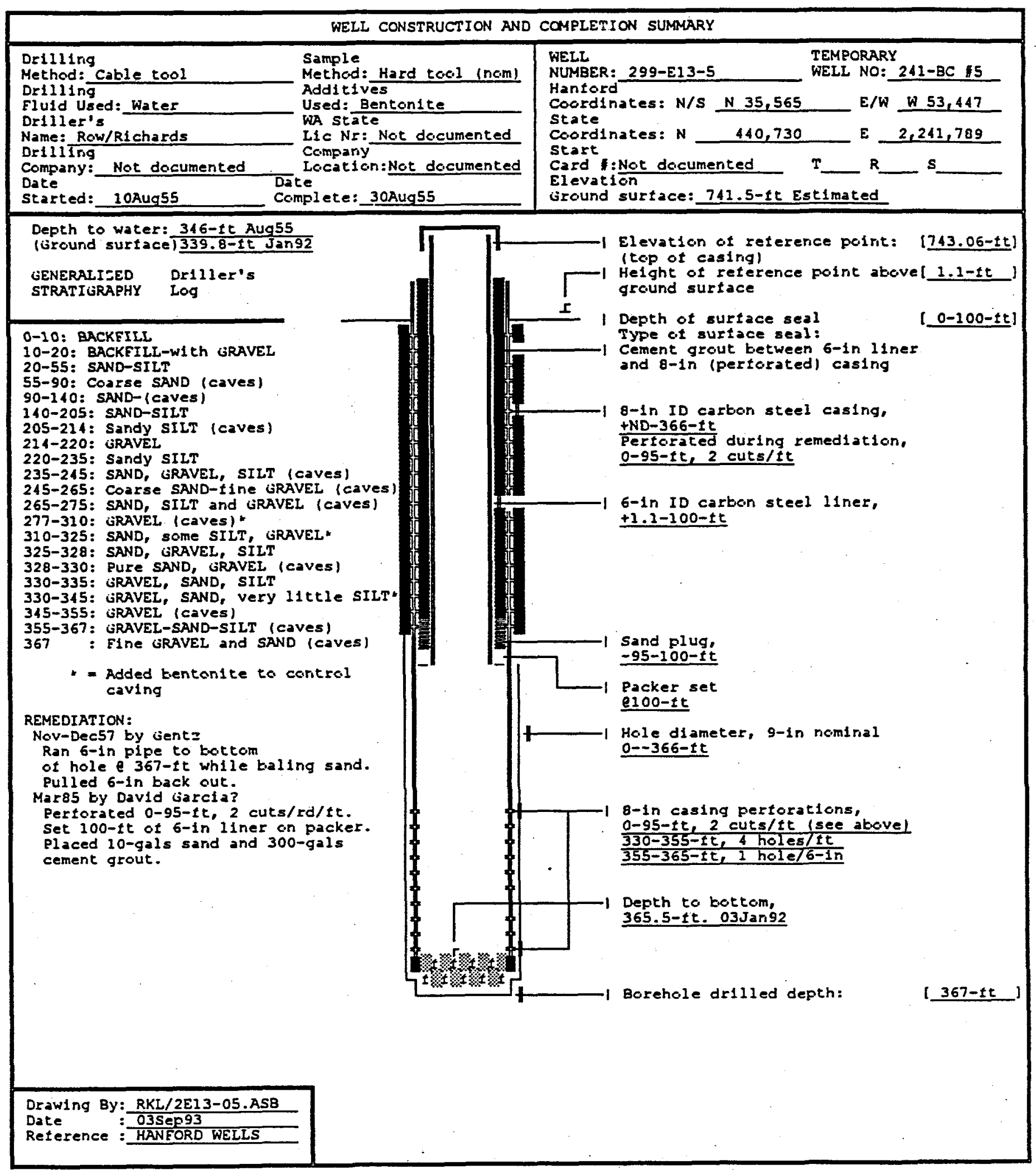




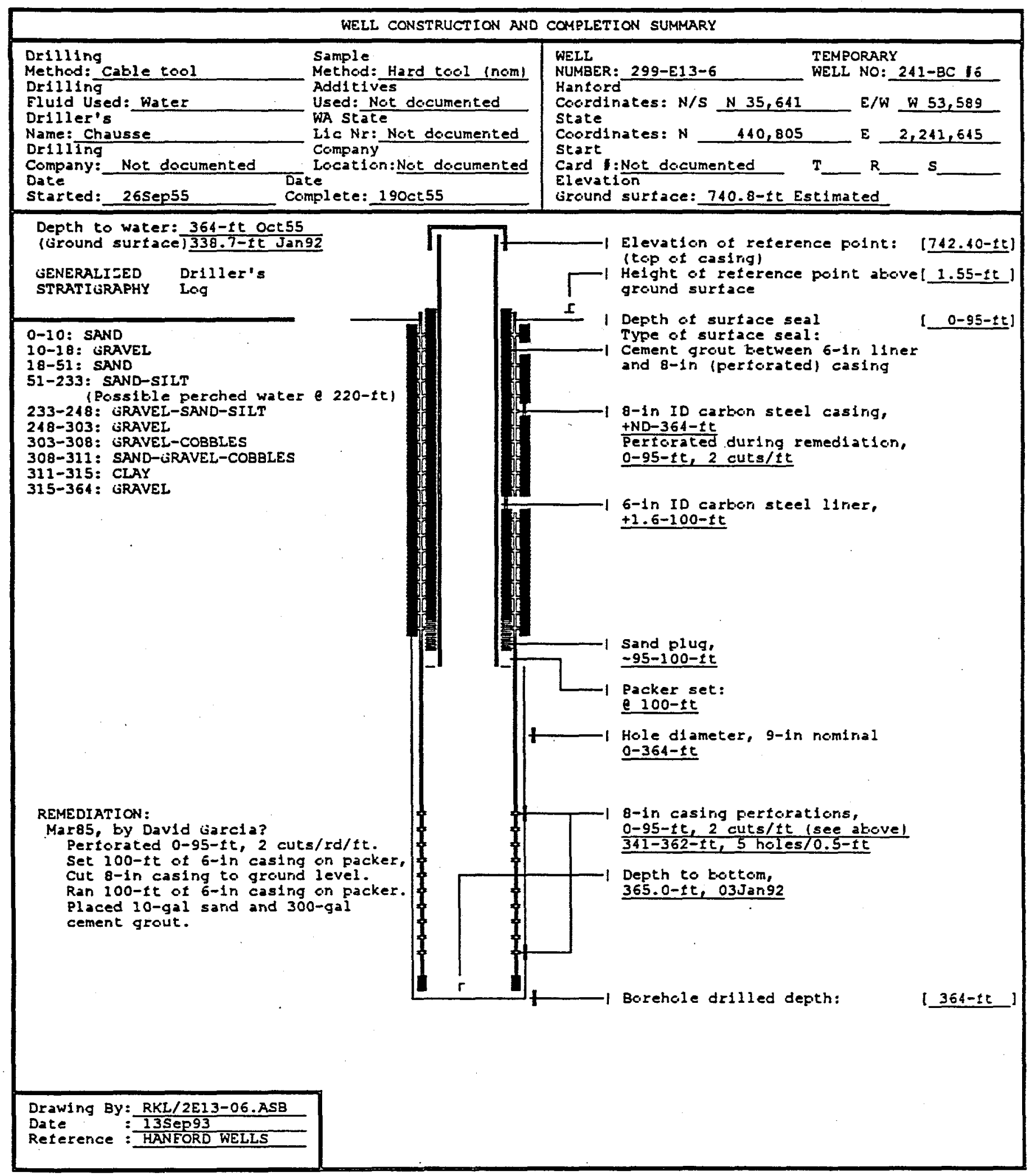




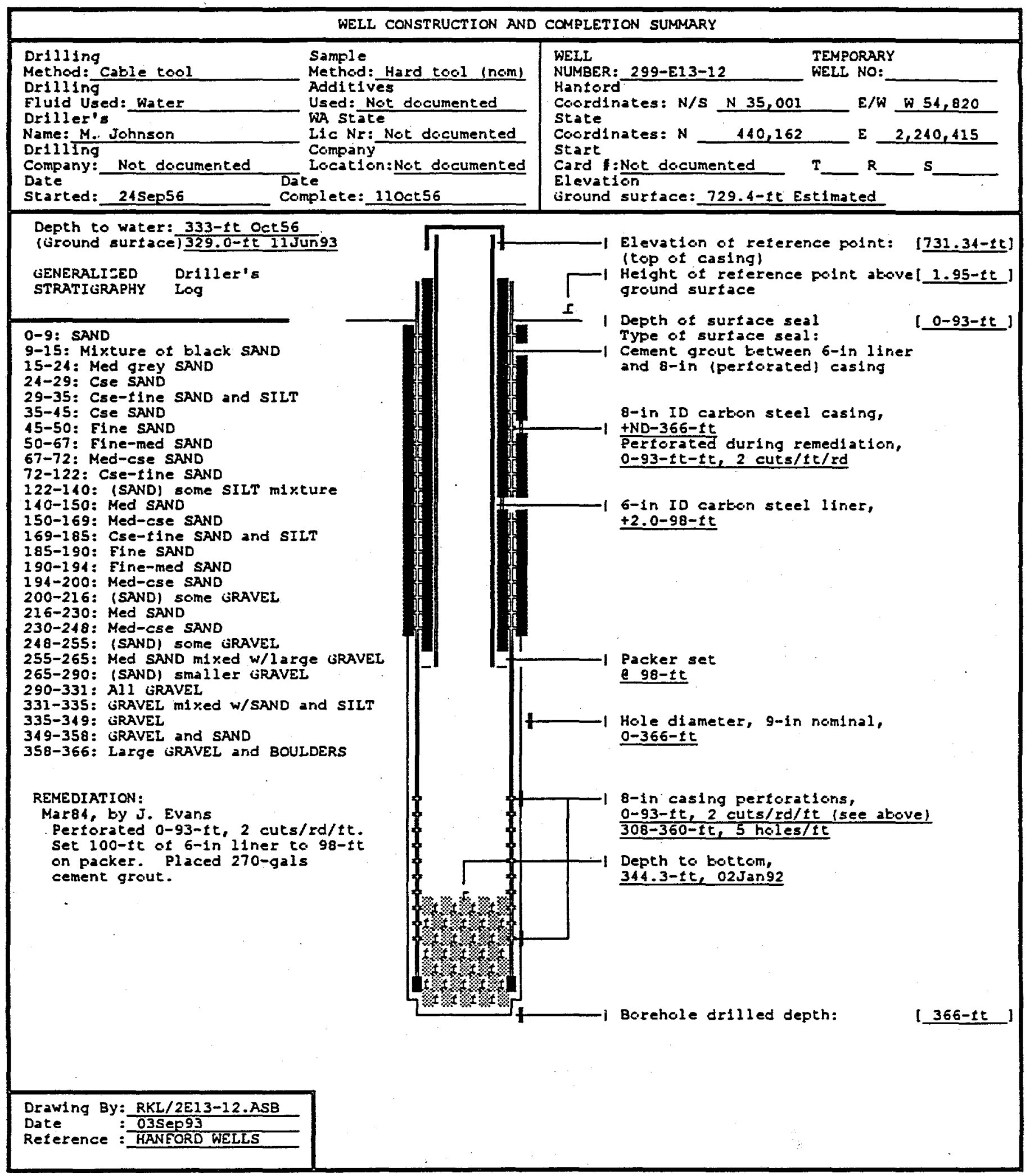




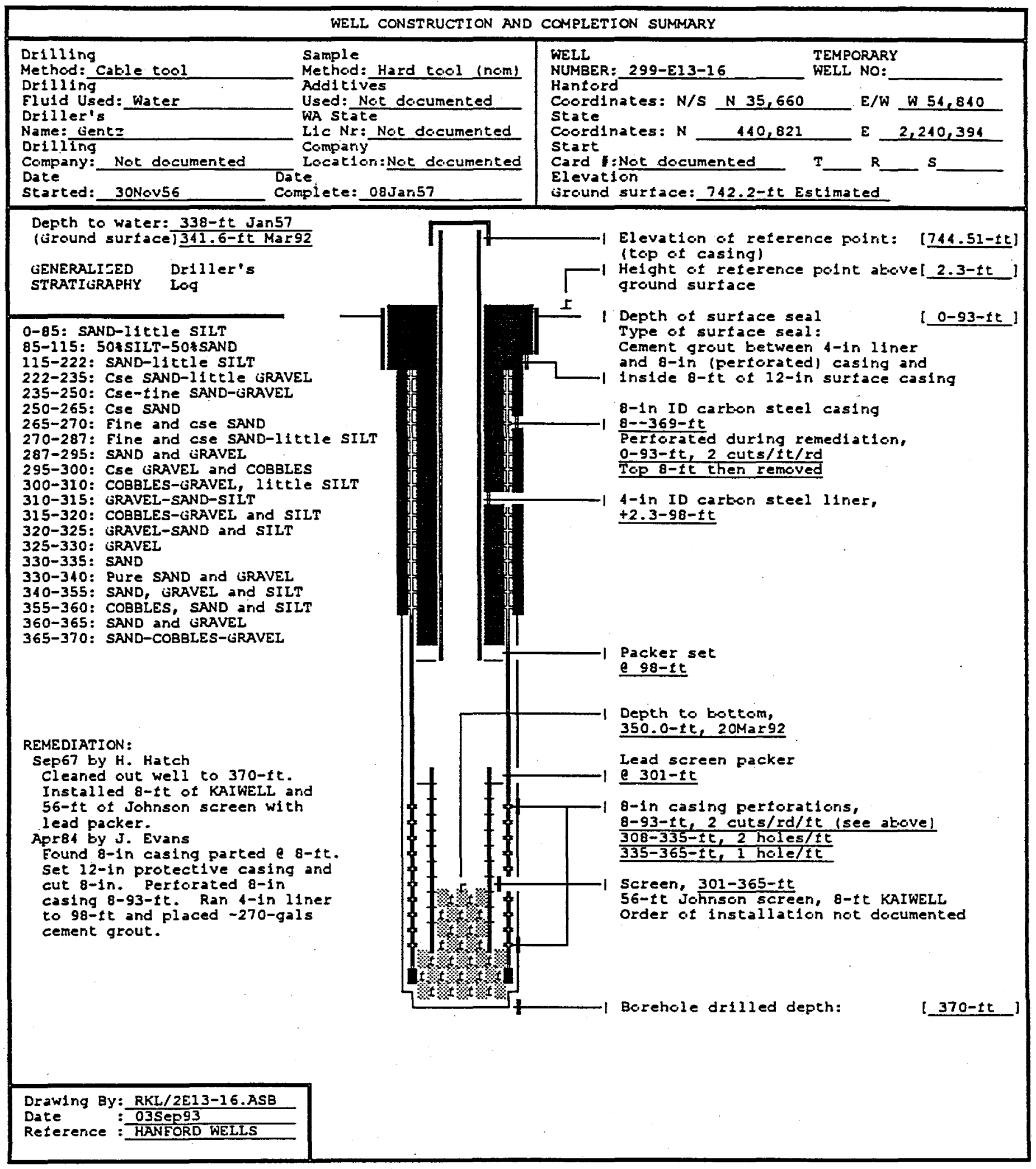




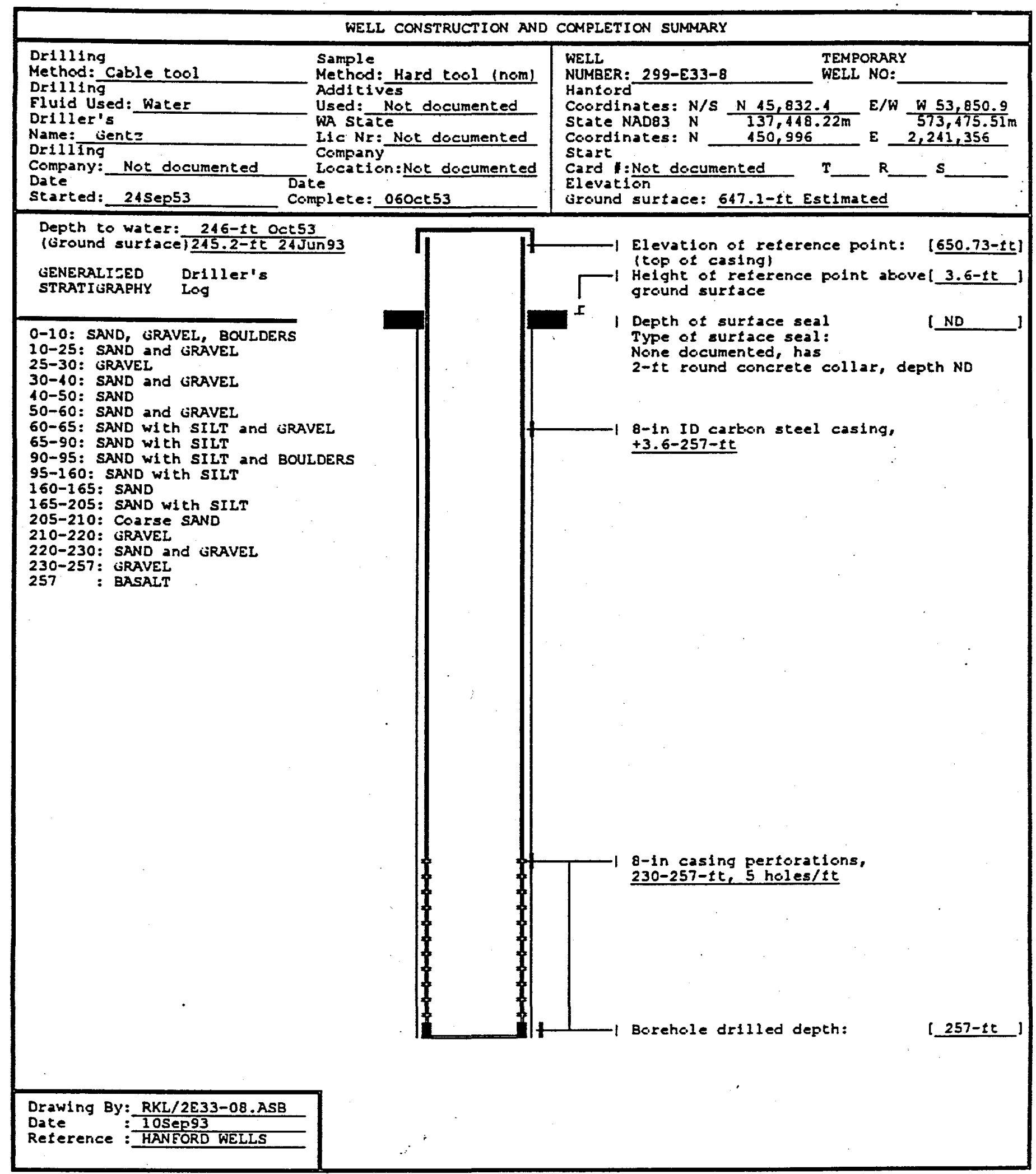


WELL CONSTRUCTION AND COMPLETION SUMMARY

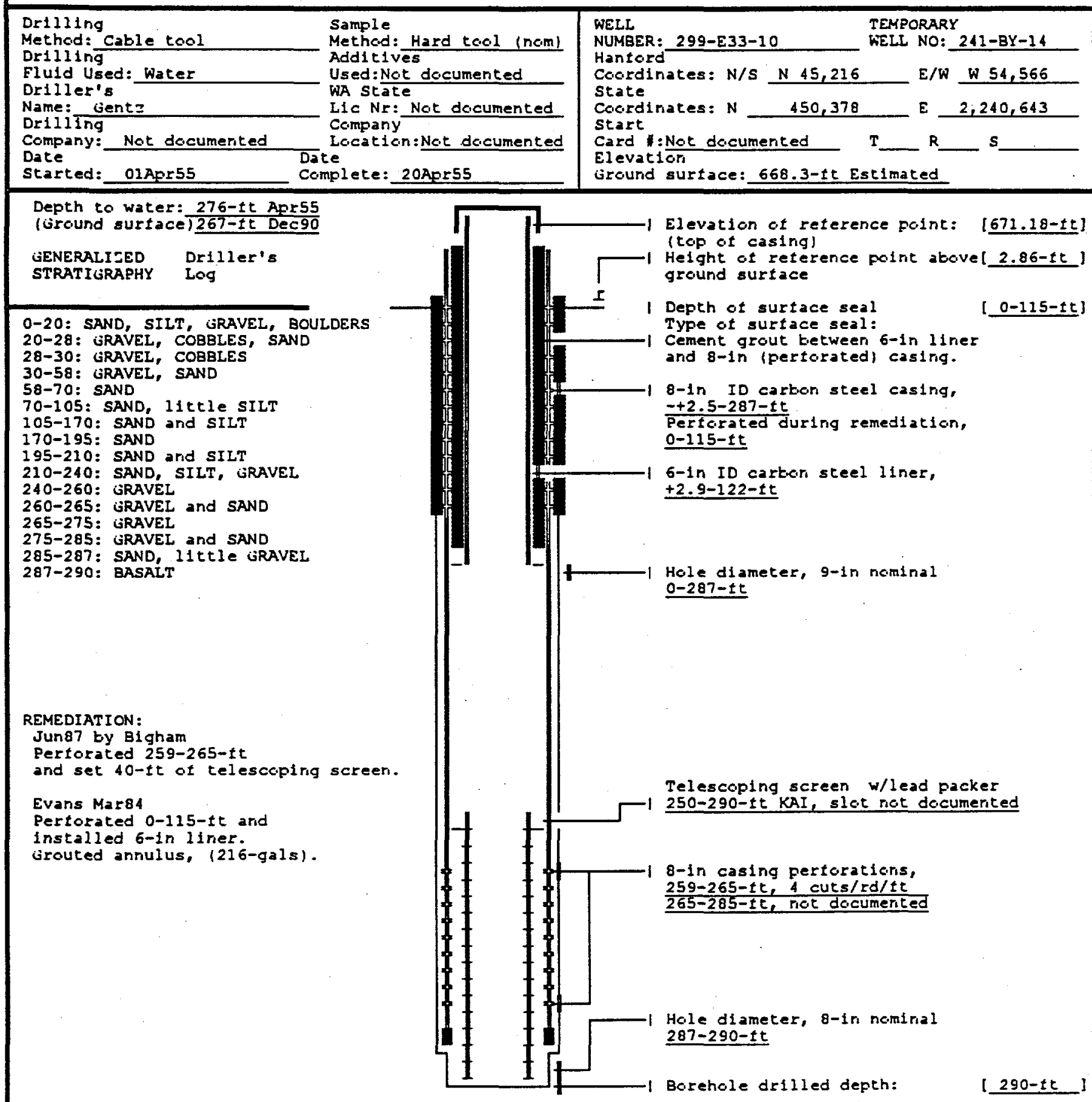

Drawing By: RKL/2E33-10.ASB

Date : 10 Sep93

Reterence: HANFORD WELLS 


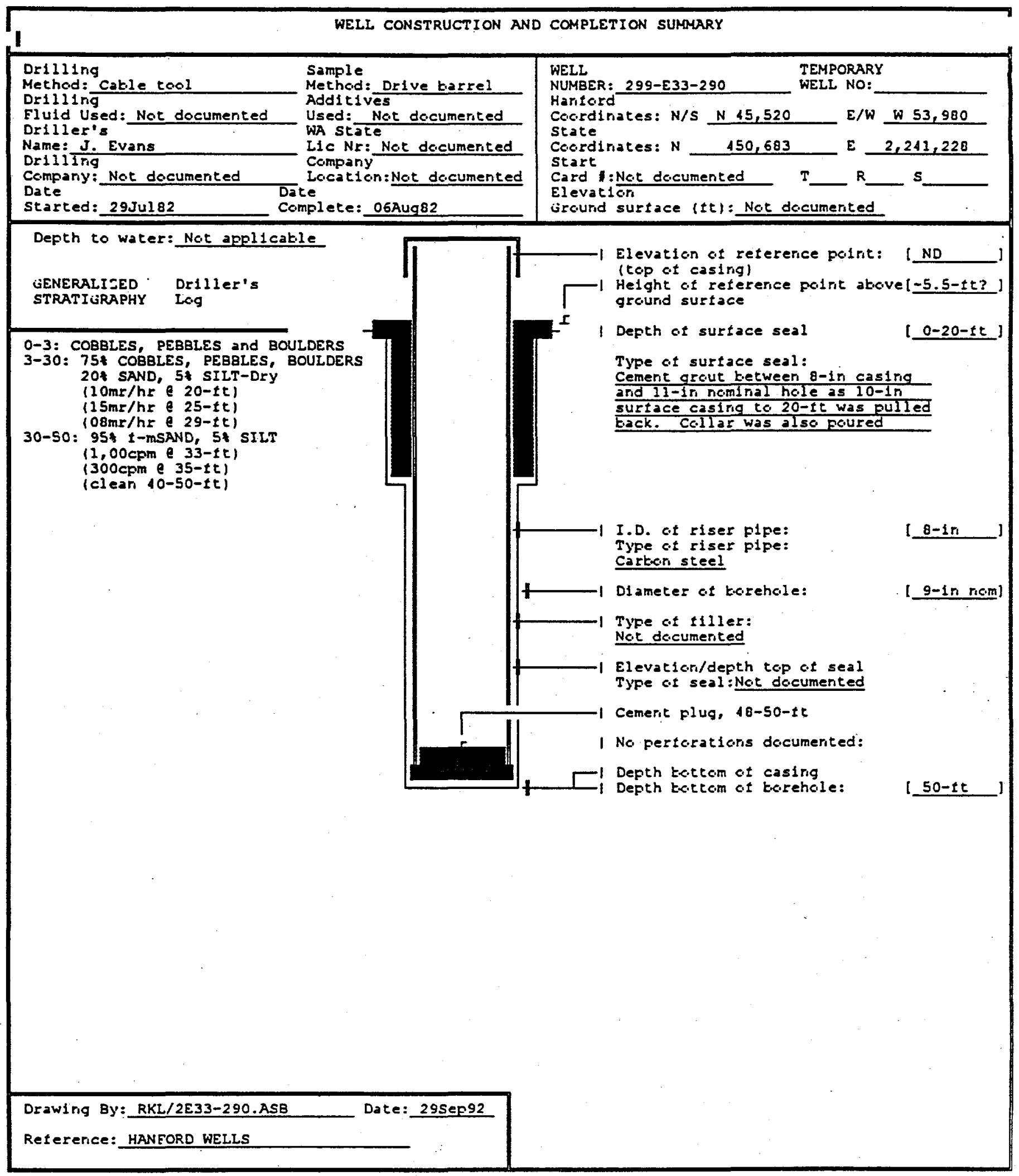




\section{Distribution}

No. of

Copies

\section{OFFSITE}

R. Randall

3 Rivers Scientific

3659 Grant Court

West Richland, WA 99352

\section{ONSITE}

3 DOE Richland Operations Office
M. J. Furman
$\mathrm{H} 0-12$
R. D. Hildebrand
K. M. Thompson
$\mathrm{H} 0-12$
Waste Management Federal Services, Inc., Northwest Operations
J. E. Meisner
H1-13

21 Pacific Northwest National Laboratory
G. R. Holdren
K6-81
D. G. Horton (10)
K6-81
G. V. Last
K6-81
S. P. Reidel
K6-81
R. M. Smith
K6-96
Information Release Office (7)
K1-06

Distr.1 